\title{
Photovoltaic Manufacturing Technology, Phase 1
}

NREL/TP--214-4579

DE92 001199

\section{Final Subcontract Report} 9 January 1991 - 1 April 1991

M. Izu

Energy Conversion Devices, Inc.

Troy, Michigan

NREL technical monitor: R. Mitchell

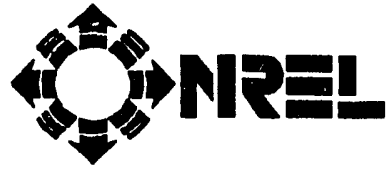

National Renewable Energy Laboratory

(formerly the Solar Energy Research Institute) 1617 Cole Boulevard Golden, Colorado 80401-3393

A Division of Midwest Research Institute Operated for the U.S. Department of Energy under Contract No. DE-AC02-83CH10093

Prepared under Subcontract No. XC-1-10057-11

March 1992 


\section{On September 16, 1991 the Solar Energy Institute was designated a national laboratory, and its name was changed to the National Renewable Energy Laboratory.}

\section{NOTICE}

This report was prepared as an account of work sponsored by an agency of the United States government. Neither the United States government nor any agency thereof, nor any of their employees, makes any warranty, express or implied, or assumes any legal liability or responsibility for the accuracy, completeness, or usefulness of any information, apparatus, product, or process disclosed, or represents that its use would not infringe privately owned rights. Reference herein to any specific commercial product, process, or service by trade name, trademark, mariufacturer, or otherwise does not necessarily constitute or imply its endorsement, recommendation, or favoring by the United States government or any agency thereof. The views and opinions of authors expressed herein do not necessarily state or reflect those of the United States government or any agency thereof.

\section{Printed in the United States of America Available from: \\ National Technical Information Service \\ U.S. Department of Commerce 5285 Port Royal Road Springfieid, VA 22161}

Price: Microfiche A01 Printed Copy A05

Codes are used for pricing all publications. The code is determined by the number of pages in the publication. Information pertaining to the pricing codes can be found in the current issue of the following publications which are generally available in most libraries: Energy Research Abstracts (ERA); Government Reports Announcements and Index (GRA and I); Scientific and Technical Abstract Reports (STAR); and publication NTIS-PR-360 available from NTIS at the above address. 


\section{Table of Contents}

PAGE

Executive Summary

TASK 1: Current Manufacturing Procedures.

I. Introduction 3

II. Deposition Plant for the Production of Solar Cells 3

1. Substrate Washing Machine 3

2. Back Reflector Machine 9

3. Amorphous Silicon Alloy Deposition Machine 13

4. Transparent Conductor Deposition Machine 19

III. Module Assembly Plant 23

IV. Products 26

TASK 2: Potential Improvements in Manufacturing Processes. $\quad 43$

I. Overview 44

II. Review of Status of ECD's Technologies which are 46 Applicable for the Potential Improvements in Manufacturing Processes.

1. ECD's Multiple-Band-Gap, Multiple-Junction 46 Technology for Stable High Efficiency Solar Cells

2. ECD's Microwave Plasma Assisted CVD Technology 53 for High Rate Deposition of Amorphous Silicon

III. Long Range Potential Benefits of the Improved Processes 56

Task 3: Problems that may Impede the Achievement of the

Potential Benefits Described in TASK 2

I. Anticipated Problems for Transferring Multiple Band-Gap. Triple-Cell Technology to Roll-To-Roll Manufacturing 58 Processes 
Table of Contents

continued

TASK 3 Continued:

2. High Quality Doped Layers 59

3. High Quality Intrinsic Layer 60

4. Device Design 61

5. Device Current Matching 61

II. Anticipated Problems in Developing Microwave Plasma assisted CVD High Deposition Rate Mass Production 62 Technology

III. Other Areas Where Process Improvements Can Contribute to Manufacturing Cost Reduction

Task 4: Technical Approach and Time/Cost Estimate. $\quad 64$

I. Overview 65

II. Procedures and Equipment 66

III. Technical Approach 69

1. Improving the Roll-To-Roll Manufacturing Technology by Incorporating Multiple Band-Gap, Multiple-Junction Structure 69

2. Incorporating Microwave Manufacturing Technology 71

$\begin{array}{ll}\text { Figures } & 79\end{array}$

$\begin{array}{lr}\text { References } & 80\end{array}$ 


\section{EXECUTIVE SUMMARY}

During the past ten years, Energy Conversion Devices, Inc. ("ECD"), has made important progress in the development of materials, device designs, and manufacturing processes required for the continued advancement of practical photovoltaic technology. Among these accomplishments, ECD has pioneered and continues development of two key technologies with significant potential for achieving the cost goals necessary for widespread growth of the photovoltaic market: (1) a low cost, roll-to-roll continuous substrate thin film solar cell manufacturing process, and (2) a high efficiency, monolithic, multiple-junction, spectrum splitting thin film amorphous silicon alloy device structure. Commercial production of multiple-junction amorphous silicon alloy modules has been underway at ECD for a number of years using the proprietary rcll-to-roll process and ongoing research has produced advances in device design and thin film deposition technology. This work has resulted in the demonstration of important increases in energy conversion efficiency and manufacturing process throughput. As a result, ECD currently holds the worlds' record for energy conversion efficiency of an amorphous silicon alloy solar cell device and ECD has also reported on development of a proprietary process for plasma CVD deposition of high quality amorphous silicon alloy films at deposition rates 5 to 10 times greater than those currently employed in the photovoltaic industry.

This report details the current status of ECD's photovoltaic manufacturing technology and describes recent technological achievements in device designs and advanced deposition and module fabrication processes which can bring about substantial cost reductions in future solar cell manufacturing. Near term target goals for solar cell modules produced with these new technologies are large volume manufacturing costs of less than $\$ 1.00$ per peak watt and stable module energy conversion efficiencies of over 10\%. Technical issues to be addressed in incorporating this technology into practical manufacturing systems are discussed and a detailed program with cost and time estimates to investigate and solve these problems is proposed. 
TASK 1

CURRENT MANUFACTURING PROCEDURES 
I. INTRODUCTION:

The present Troy based manufacturing plant produces amorphous silicon based solar cells and photovoltaic modules which use a two cell, same band-gap, tandem cell configuration (Figure 1). ECD's proprietary roll-to -roll continuous substrate process produces complete solar cell structures on stainless steel rolls. Typically, 2,500 feet long 14 inch wide 5 mil thick stainless steel rolls are processed. The stainless steel rolls are coated consecutively with a metallic back reflector, six layers of amorphous silicon alloy and a transparent conducting oxide top contact layer. The rolls are then cut into appropriate sizes for assembly into photovoltaic modules. The manufacturing plant has been running in an extremely consistent manner producing solar cells with an average active area efficiency of about $8 \%$ to $9 \%$ with excellent yield.

ECD has been awarded over 120 U.S. patents covering all aspects of its proprietary approach to the mass production of amorphous silicon alloy material solar cells. The patents cover novel materials, solar cell and module designs, preparation techniques and production machine technology.

ECD's proprietary solar cell manufacturing is divided into two distinct process sequences - roll-to-roll solar cell jeposition and module assembly. The ability to divide manufacturing into these two sequences which can, if desired, occur in quite different locations, is a unique consequence of our process.

Specifically, solar cell production involves the following process steps and equipment.

\section{Ii. DEPOSITION PLANT FOR THE PRODUCTION OF SOLAR CELLS:}

\section{Substrate Washing Machine}

The substrate washing machine is a continuous roll-to-roll processing system which transports a stainless steel substrate through a detergent cleaning station, multiple deionized water rinsing baths, 


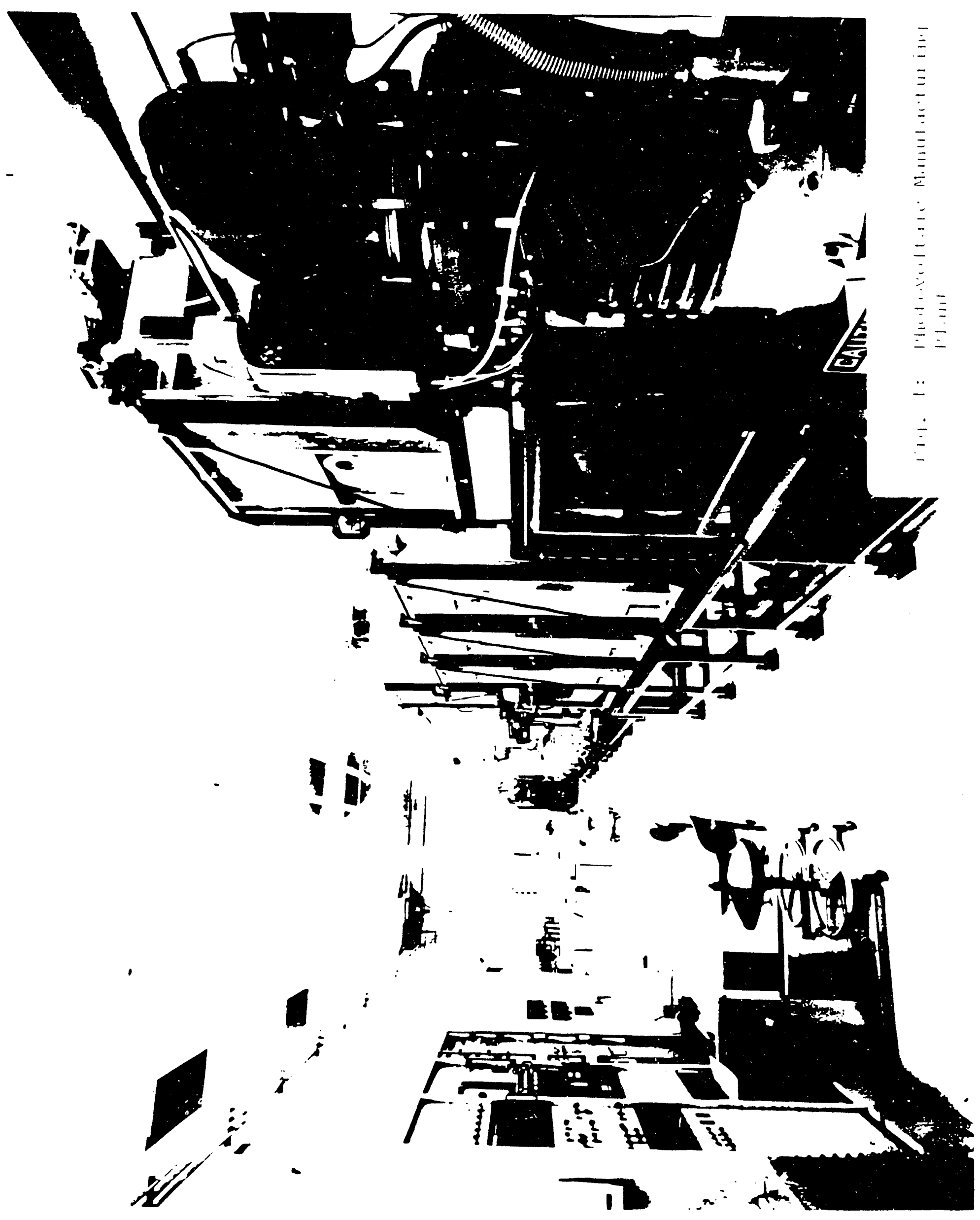


and an oven drying stage to produce a clean, dry, particle-free substrate suitable for amorphous silicon deposition.

The input to the substrate washing machine is a roll of commercially available stainless steel, up to 2,500 feet long, which is loaded onto a mandrel designed to accept the steel supplier's core. During the washing stage, the interleaf from the steel supplier's roll is taken up by the machine and discarded. After washing, the cleaned substrate is rolled on a special core which is used throughout the remainder of the deposition process.

The substrate washing machine consists of the following consecutive units mounted in line on a structural steel framework:

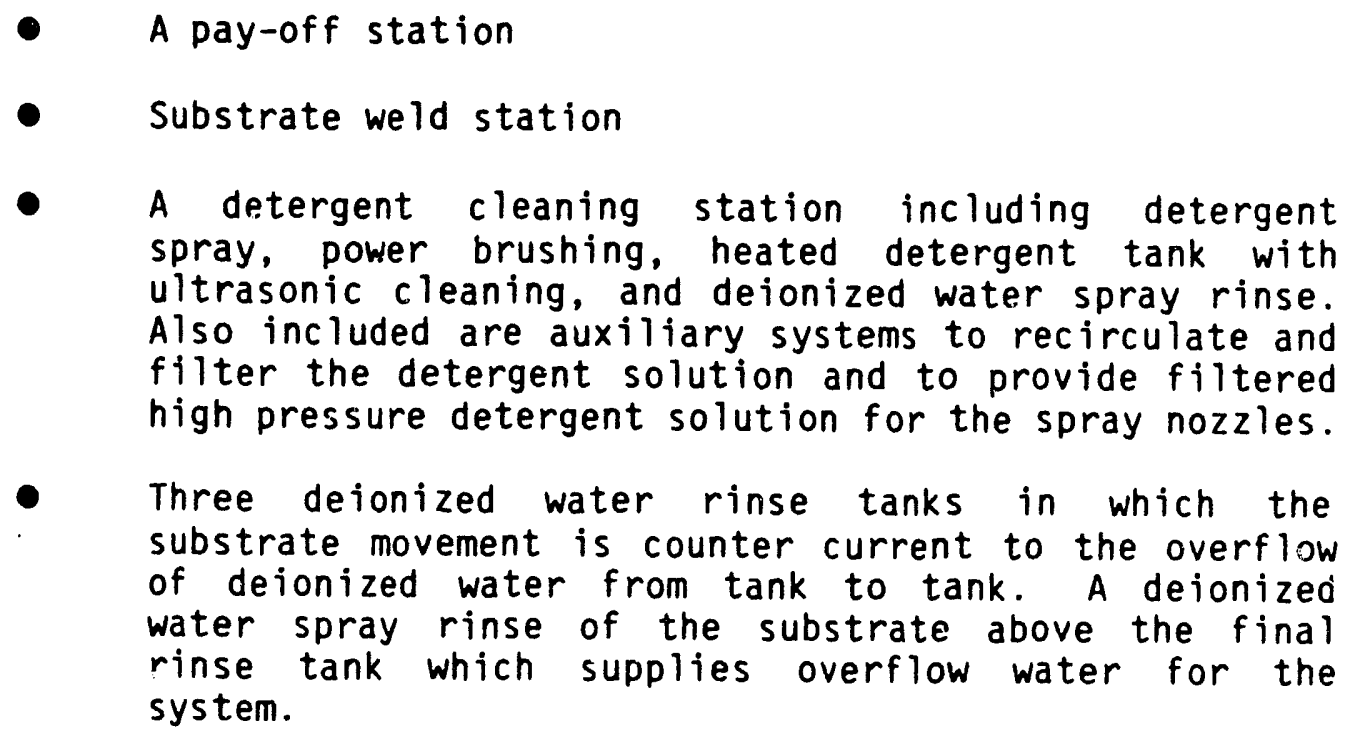

- Heated deionized water system.

An enclosed drying oven containing quartz infrared lamps.

A take-up station located in a dust free area.

The current washing machine has the capacity to process over 300,000 square feet of substrate per year. The maximum substrate width capability is 14 inches and the substrate speed operating range is up to 2 feet per minute. The substrate washing machine is capable of fully automatic operation except for manual loading/unloading of coils. 
A control panel is provideo to allow display and control capability for the following process variables:

- Pay-off spindle motor: torque and speed

- Pay-off interleaf motor: torque and speed

- Brush speed

- Detergent brushing tank: solution temperature

- Detergent cleaning tank: solution temperature

- Drying oven: oven temperature

- Steering roll position

- Take-up spindle motor: torque and speed

- Indicating lights for all systems requiring power

- Indication of pressure drop across both detergent spray and detergent circulation filter systems

- Flow indication of all pump discharge lines

- Indication of deionized water resistivity in each of the three deionized water rinse tanks

- Emergency stop capability

Incoming materials to the substrate washing machine include:

1. Bright annealed stainless steel substrate with interleaf (up to 2,500 feet long coils, 14 inches wide, 0.005 inches thick)

2. Caustic detergent solution

3. Deionized water ( $10 \mathrm{meg}$ ohm. $\mathrm{cm}$. or greater)

A schematic diagram and photograph of the substrate washing machine are shown in figures 2 and 3 respectively. 


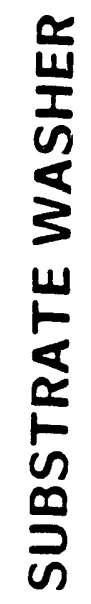

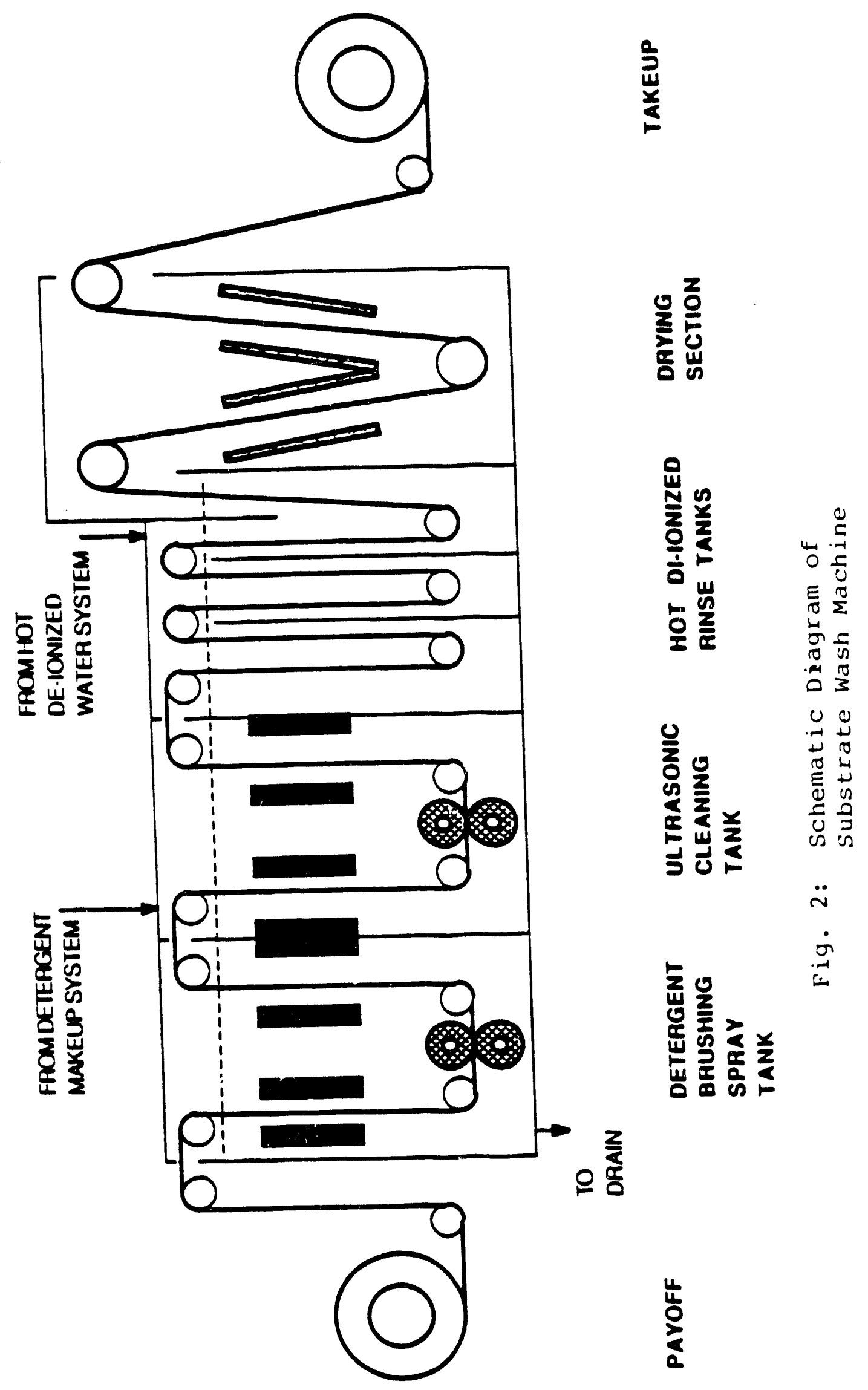




\section{Back Reflector Machine}

The back reflector deposition machine is a continuous roll-to-roll processing system which deposits a reflective metal alloy layer/buffer layer film system onto the cleaned stainless steel substrate. The back reflector system adheres to the stainless steel and texturizes the surface to provide a diffuse optically reflective layer which enhances absorption of the solar spectrum. The proprietary metal and buffer layers provide ohmic contact to the solar cell and improved reflection.

Input to the back reflector machine is a roll of cleaned stainless steel from the substrate washing machine. Substrate rolls up to $z, 50$ feet long and weighing up to 1,000 pounds can be handled. The beginning of a new roll leader is welded to the trailing edge of the previous substrate for threading through the machine. The processed substrate is rolled up with an interleaf.

The system consists of a pay-off section designed for substrate loading, a multi-zone process section where the sequential depositions take place and finally a take-up section. Deposition is achieved by sputtering from multiple $D C$ magrietron cathodes so as to achieve the desired thicknesses in a single pass through the system. Substrate heating is achieved by radiation from infrared quartz elements, and the rate of travel through the system is approximately 1 foot/minute.

The system utilizes diffusion pumps with liquid nitrogen vapor traps. The process chamber, pay-off chamber, and take-up chamber all can be evacuated to an ultimate pressure of $5 \times 10^{-6}$ Torr. 
The system is fully automatic during the deposition cycle with operation from an operator console. Complete manual override is provided locally for system maintenance and repair. Local controls for emergency stop/standby and for substrate threading, loading and unloading is provided.

Incoming materials to the back reflector machine include :

1. Cleaned stainless steel substrate with interleaf (up to 2,500 feet coil).

2. Proprietary deposition materials.

3. Argon and nitrogen gases.

4. Cooling water.

A schematic diagram and photograph of the back reflector machine are shown in Figure 4 and 5 . 

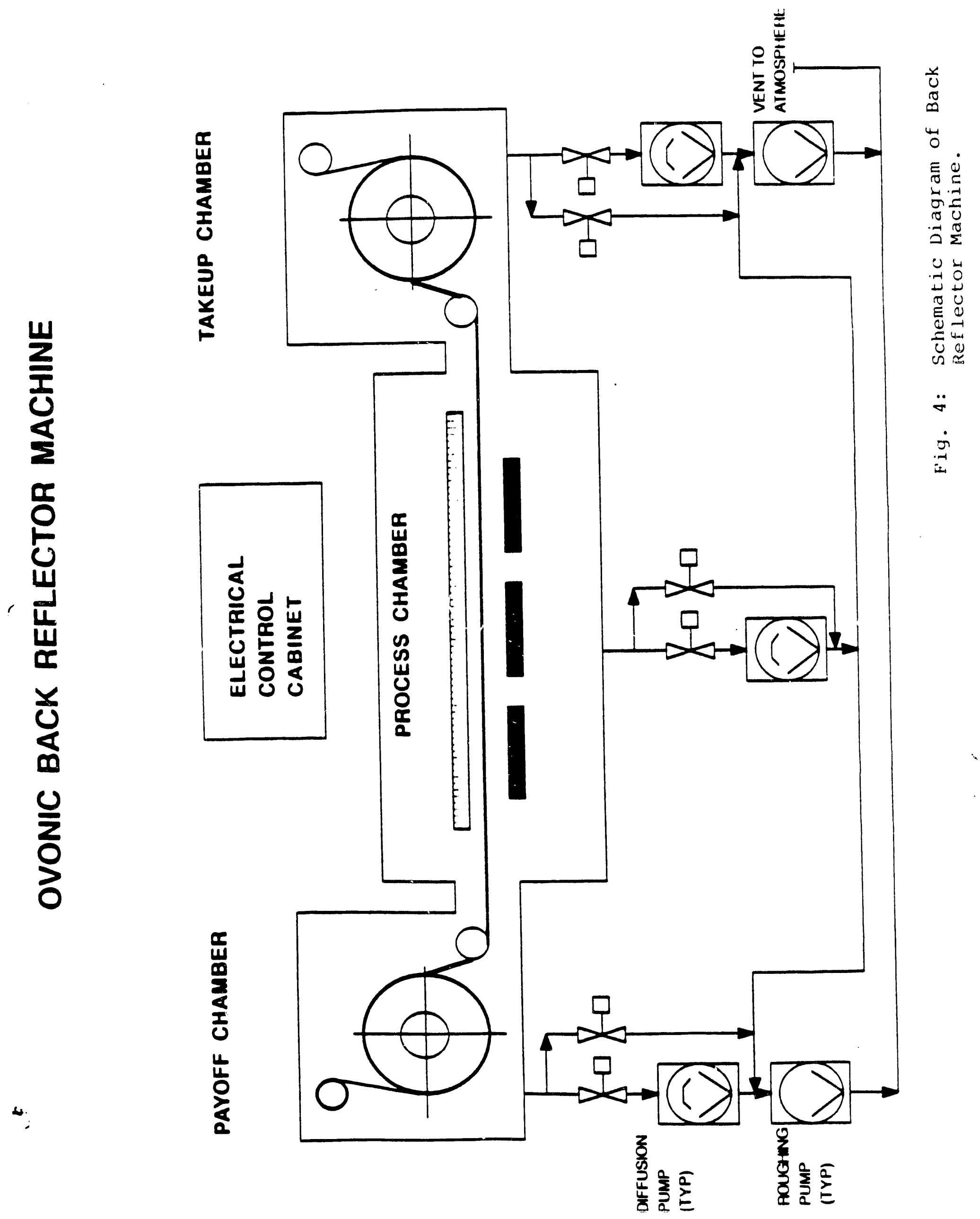


\section{Amorphous Silicon Allcy Deposition Machine}

The amorphous silicon alloy deposition machine is a continuous roll-to-roll RF-plasma CVD processing system which produces, in a single pass, sequentially deposited thin films of doped and undoped amorphous silicon alloy semiconductor material. In this machine, a mixture of feedstock gases is decomposed in a series of RF CVD plasma chambers to deposit amorphous materials continuously on the coated stainiess steel substrate. The current production equipment has six RF-plasma deposition chambers to produce $n-i-p / n-i-p$ solar cells with a same band gap tandem structure.

The input to the amorphous silicon alloy deposition machine is a roll of coated stainless steel as received from the back reflector deposition machire. Substrate rolls approximately 2,500 feet in length, 14 inches in width and weighing up to 1,000 pounds are handled routinely. The beginning of the input roll is welded to the end of the preceding roll in situ and an interleaf is used in the take up of the machine to prevent scratching of the deposited solar cell structure. Substrate transport through the system is at the rate of approximately 8 to 12 inches/minute.

The multi-section amorphous silicon alloy deposition machine consists of a pay-off chamber section, six process chamber sections for the tandem device structure and a take-up section. The process gas mixtures in each section are dynamically isolated from adjacent sections by a proprietary "gas gate." The "gas gates" utilize laminar gas flow through constant geometrical cross section conduits in a direction opposite to the diffusion gradient of the dopant gas concentrations. In this way, migration of dopants between chambers is essentially eliminated and gas mixtures in adjacent chambers are effectively isolated even though no actual physical impediment is present. Substrate transport is accomplished with controlled tension for accurate positioning of the substrate in the various process chambers and the tension is controlled in the take-up chamber to insure that the substrate is properly wound. Substrate passage through the process chambers is such that deposition takes place on the underside, and front facing in the substrate transport system is not allowed. 


\begin{abstract}
Pay-off and take-up chambers contain all of the necessary substrate drive components, auxiliary rolls, and steering mechanisms. Vacuum pumping for these chamber sections is done with Roots Blowers and mechanical displacement type vacuum pumps.
\end{abstract}

Each process chamber is comprised of a reaction zone, defined by the geometrical placement of the RF cathodes, a mixing manifold and a distribution manifold. In each process chamber, transport of reactant and diluent gases to the reaction zone is from mixing manifolds. These are designed to provide the specified mixture to the distribution manifolds in the individual reaction zones. Reaction zone manifolds are desijned to achieve uniform flow through the zone and dopant profiling as required for optimum cell performance. The pressure in the reaction zones are controlled by a gas pumping system consisting of a combination of Roots Blowers and mechanical displacement pumps, variable conductance valves, flow controllers, and pressure transducers used together in a closed loop feedback system. The reaction zone lengths are determined by the rate of substrate travel and the length of the cathodes as determined from the respective deposition rates.

All of the deposition chambers are operated continuously and each of the lasers making up the cell structure is deposited in sequence as the substrate proceeds through. The substrate is maintained at the required temperature for each deposited layer by an array of quartz envelope lamps located above the substrate and radiating downward. This array is designed to maintain temperature uniformity throughout the substrate surface. All of the material used in the reaction zone and all surfaces exposed to the reaction are 300 series stainless steel, and all other materials used in the process chambers are selected for compatibility with the process.

Effluent gases from the vacuum pumps pass through a caustic bath scrubber before being exhausted to the atmosphere. The gas scrubbers remove unreacted process gas and undesirable reaction products from the exhaust through chemical reactions with the caustic solution. A toxic gas monitor system is provided to monitor critical points at the machine, gas supply cabinet, scrubber and effluent gas chimney. 
The operation of system is automatic aiter start of deposition with operation controlled and monitored from an operator console. Complete manual override is provided locally for system maintenance and repair. Local controls for emergency stop and standby and for substrate threading, loading and unloading are provided.

Incoming materials to the amorphous silicon alloy deposition machine includes:

1. Back reflector coated stainless steel substrate with interleaf (up to 2,500 feet coil)

2. Proprietary deposition gases

3. Argon and nitrogen gases

4. Calistic solution for scrubber

5. Cooling water

Schematic diagrams and a photograph of the machine are shown in Figures 6,7 and 8 . 


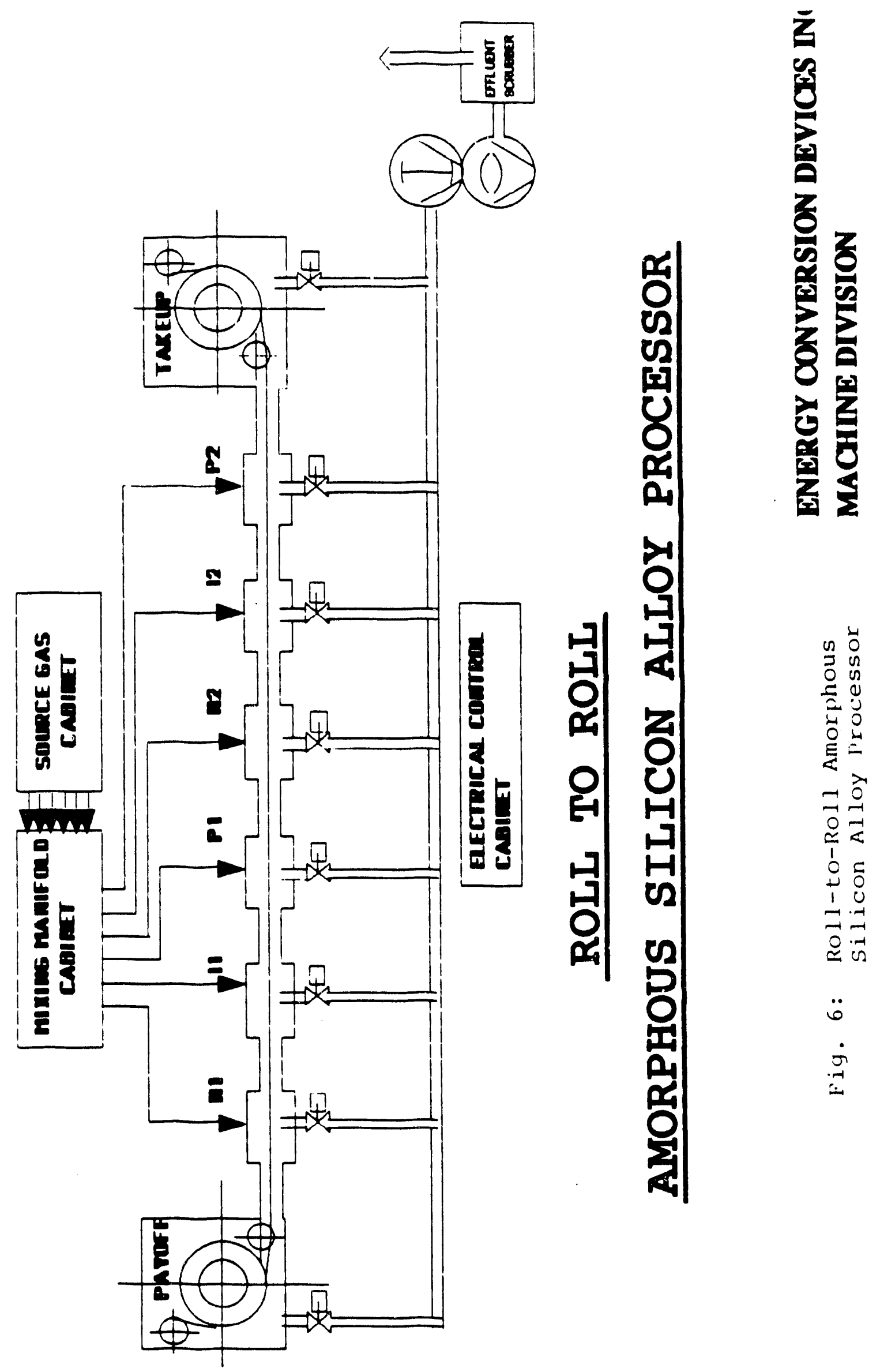



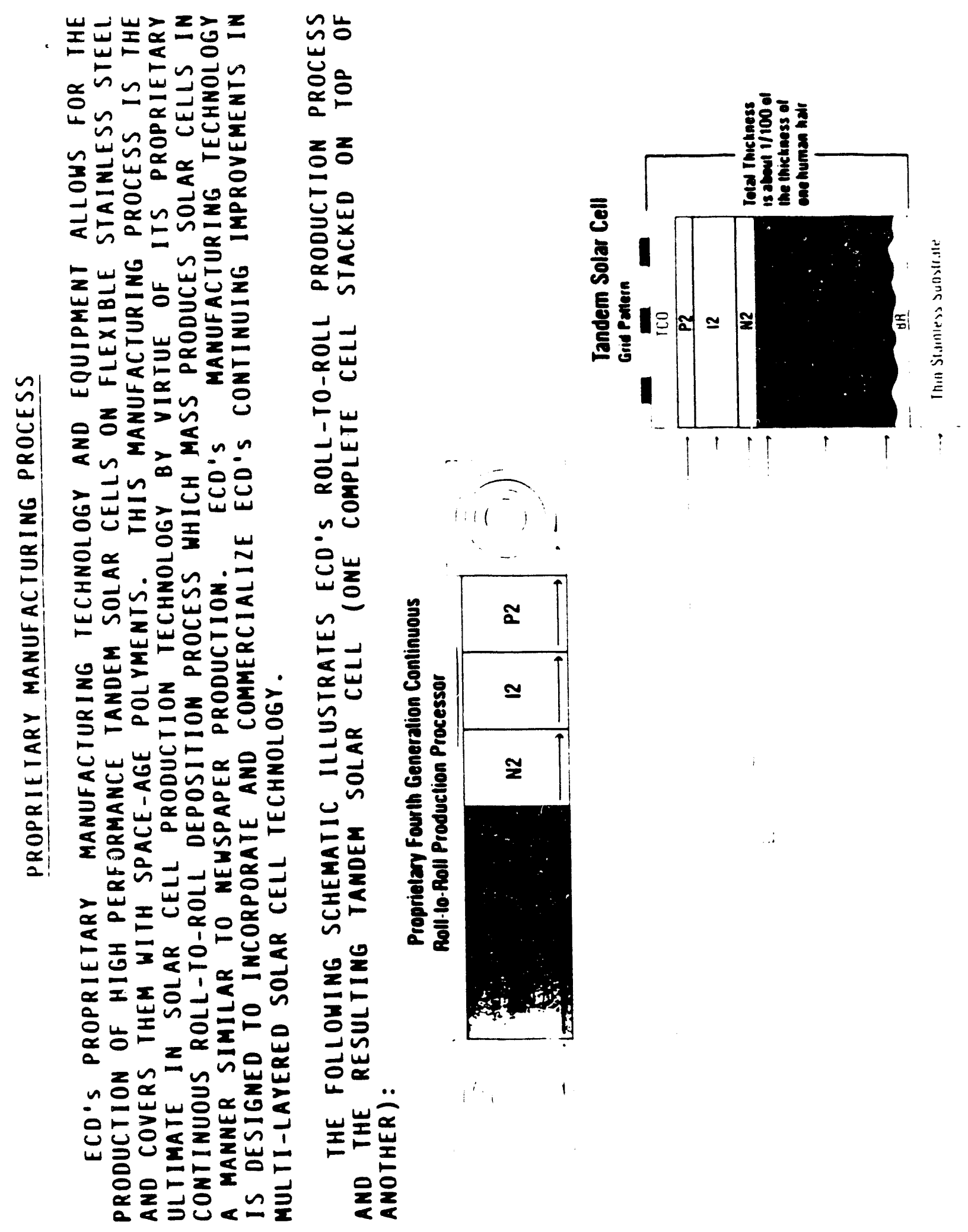


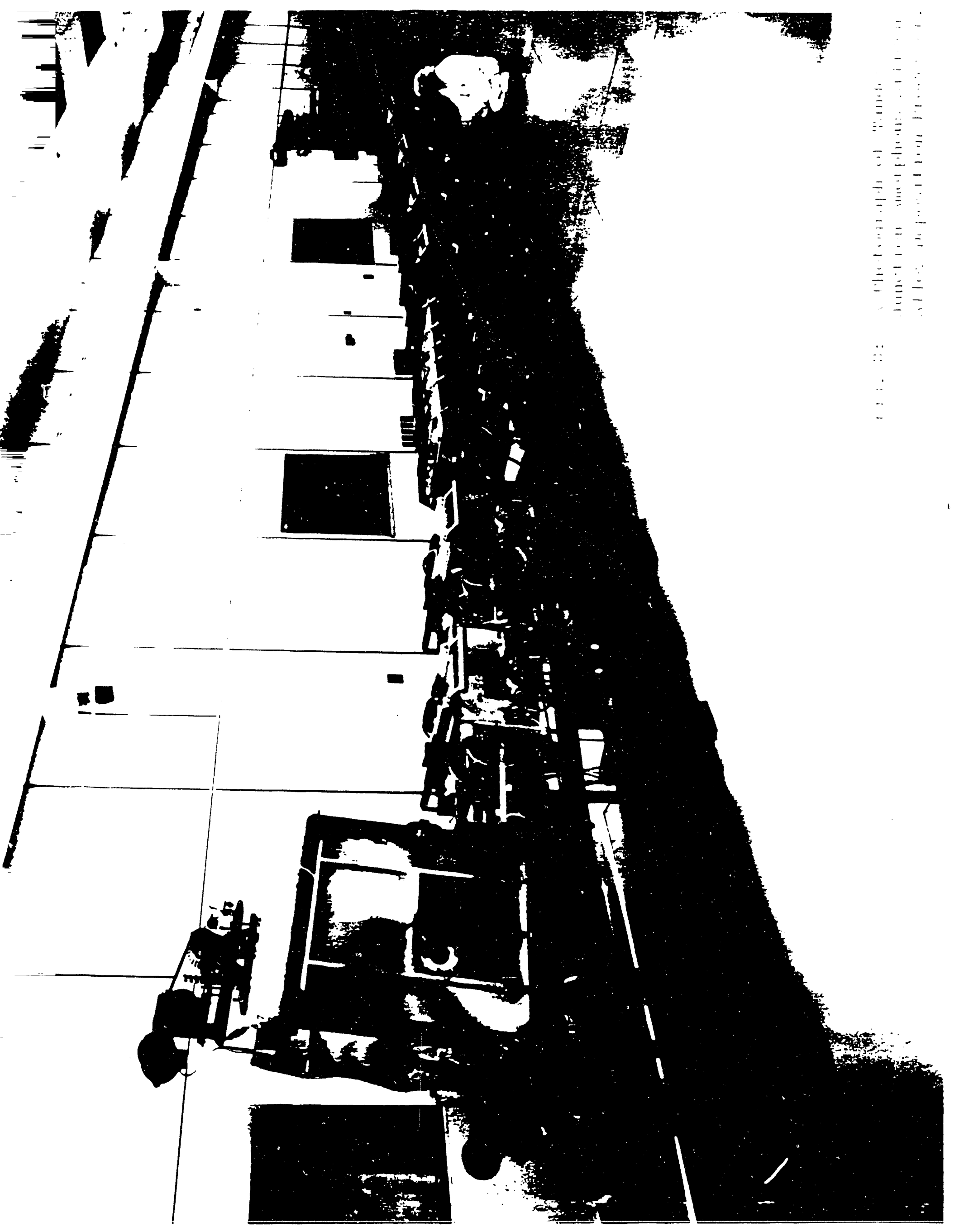




\section{Transparent Conductor Deposition Machine}

The transparent conducting oxide (TCO) deposition machine is a continuous roll-to-roll processing system which deposits a transparent electrically conauctive layer on top of the solar cell structure. This top layer has two functions. First it provides an electrical top contract between the current generating photovoltaic layers and the current collection grid. Second, it acts as an anti-reflective coating to the amorphous silicon alloy to give higher utilization of incident light.

Input to the TCO deposition machine is a roll of amorphous silicon alloy coated stainless steel up to 2,500 feet long and weighing up to 1,000 pounds. The beginning of a new roll is welded to the trailing edge of the previous substrate for threading through the machine. Interleaf is used in the take up of the TCO deposition machine.

The system consists of a pay-off section designed for substrate loading, a process section where deposition takes place and finally a take-up section. Deposition is accomplished by reactive vacuum evaporation from resistively heated sources which are present in sufficient number so as to achieve the desired TCO thickness in a single pass. During deposition, the desired substrate temperature is achieved by radiative heating from a quartz lamp-type heater array located so as to radiate onto the back side of the traveling substrate. The substrate rate of travel is approximately 1 foot/minute.

The operation of the system is automatic after start of deposition with operation and monitoring from an operator control console. Complete manual override is provided locally for system maintenance and repair. Local controls for emergency stop-standby and for substrate threading, loading and unloading is provided. 
Incoming materials to the TCO deposition machine include:

1. Amorphous silicon alloy coated stainless steel substrate (2500 feet coil)

2. Proprietary deposition metal

3. Oxygen gas

4. Nitrogen \& argon gas

5. Cooling water

Schematic diagram and a photograph of the machine are shown in Figure 9 and 10 . 


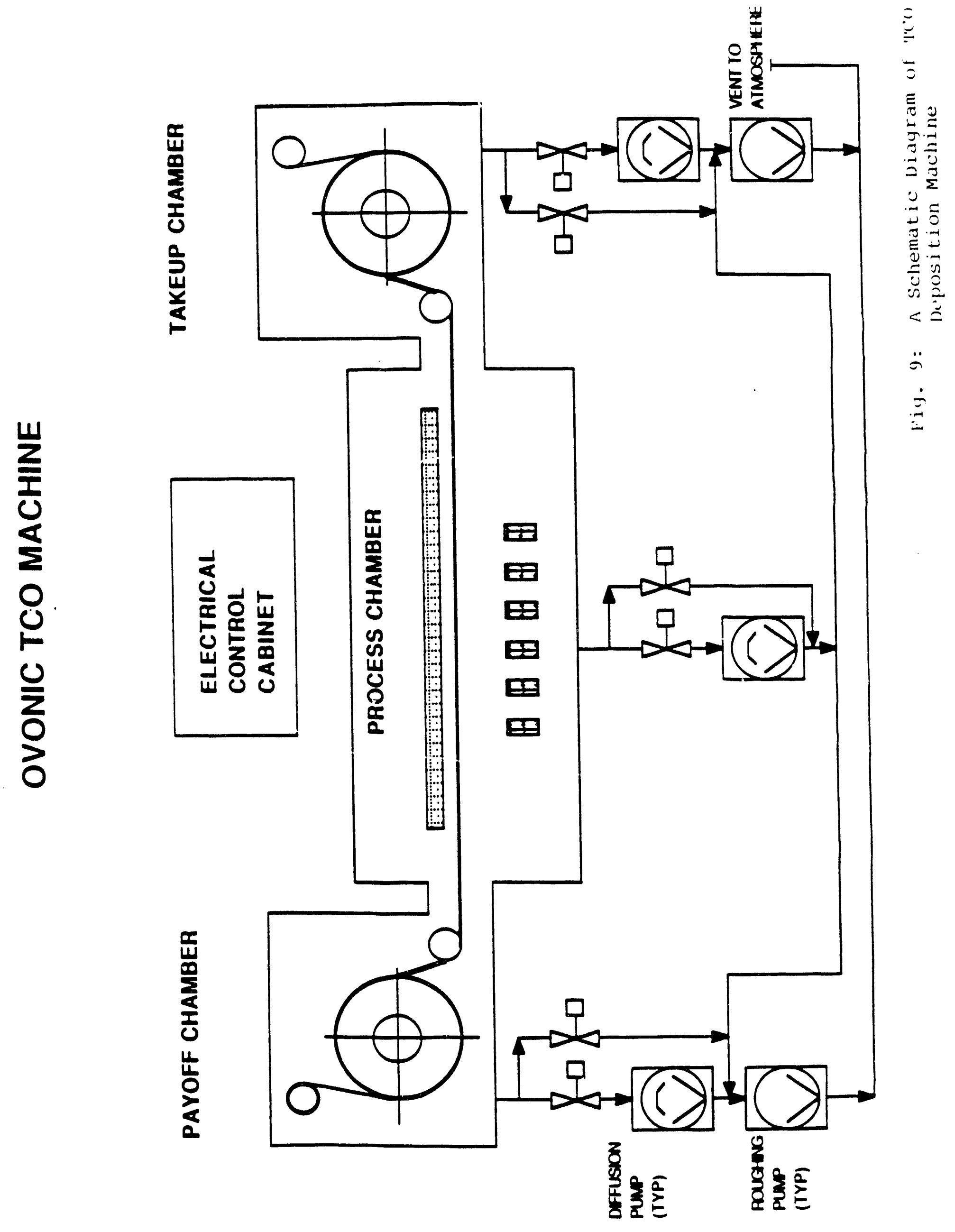




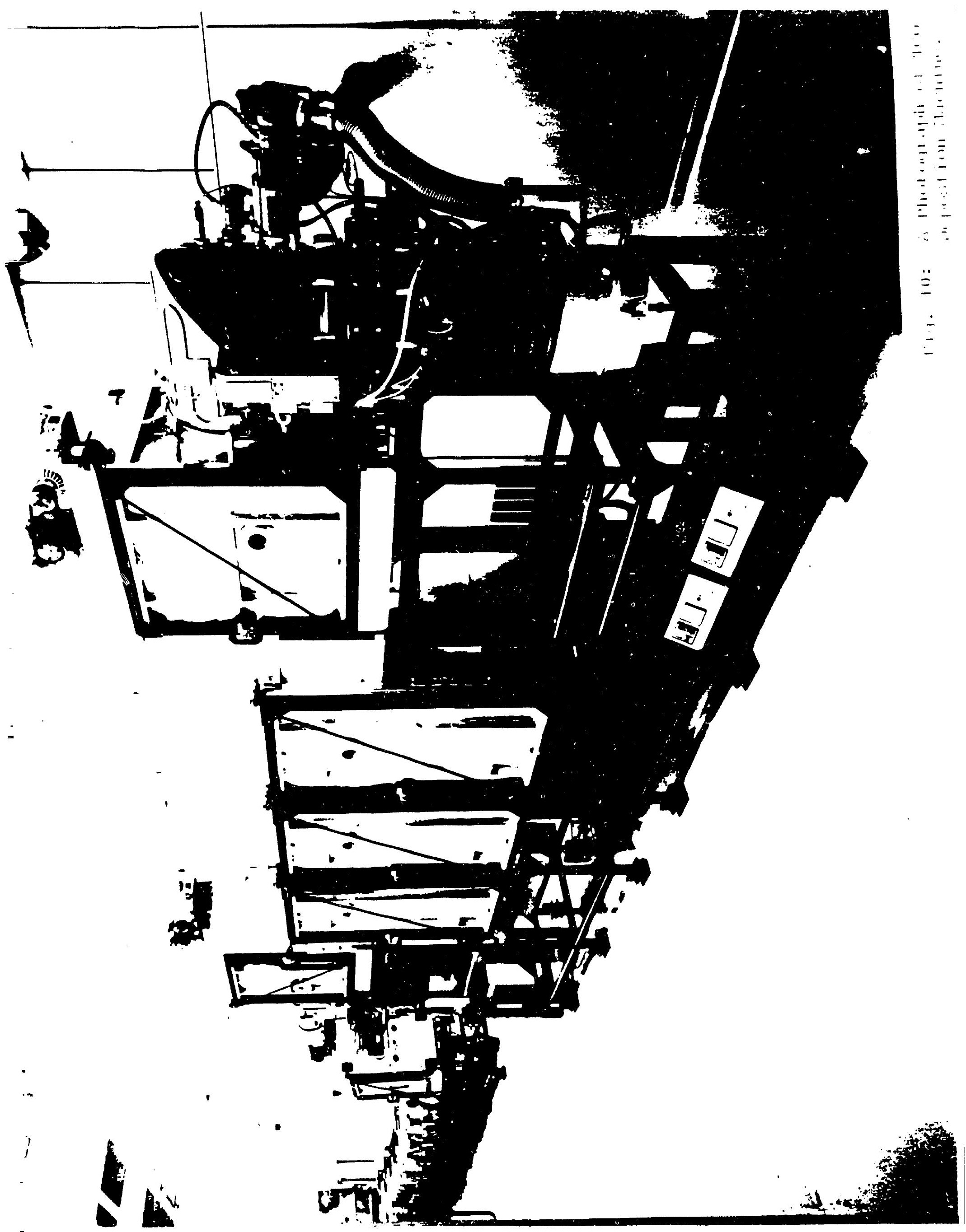




\section{MODULE ASSEMBLY PLANT}

The current module assembly plant is totally self-sufficient, requiring no proprietary technologies from cther companies. The current processes, developed at ECD, are mostly manual and can benefit greatly from automation.

The individual processing steps will now be described. They appear in operational order.

\section{Slabbing}

"Slabbing" is the first operation in the module assembly plant. In this step the approximately $2,500 \mathrm{ft}$. long rolls of photovoltaic coated stainless steel material are cut into "slabs" about $4 \mathrm{ft}$. long. Also during the "slabbing" process 4" wide strips called "Coupons" are cut at predetermined intervals and used for quality control and assurance (QA/QC) of the photovoltzic deposition process.

2. $Q A / Q C$

An intensive $Q A / Q C$ prograin is used to analyze and control the deposition process. It consists of actually fabricating working solar cells in small areas on the coupons produced in the "slabbing" step and performing varinus tests to determine the quality of the solar cell deposition process.

Coupon processing, which is similar to actual large-area cell processing, begins with a scribbing step in which an etchant paste material is screen printed onto the TCO covered cell area in order to remove TCO to define individual cells. After the etchant is deposited on ihe coupon, it is heated to activate the etching process. After a specified time, the paste is removed by rinsing in water. While the coupon is still wet, it is placed into a bath containing an electrolyte solution. A reverse bias 
DC potential is applied between the coupon and a counter electrode at fixed spacing in the solution for a predetermined time. Current flow through this circuit now occurs preferentially through those regions of the cell which are shunted and this causes a chemical reaction in which the TCO becomes non-conducting. 9 In this way, shorted regions of the cell are electrically isolated so they will not degrade the performance of other, parallel connected sell regions. Once shorts are passivated in this way, the coupon is dried and ready for silver ink screening. The silver ink provides a conductive grid for current collection in the individual cells.

The finished cell coupons are then tested for function. The principal test is an AMI.5 global illumination test to determine energy conversion efficiency. Statistics on coupon performance are tabulated to keep track of yielc. Other tests are also possible at this point including measurements which can provide the current collection ability of each of the constituent cells. Other information, such as conductance of the $\mathrm{Ag}$ paint and TCO, can also be collected. The data from each coupon is stored in a data base, and summarized as quality control parameter for the entire 2,500 ft. long roll.

\section{Scribing}

Scribing is performed on the $1^{\prime} \times 4^{\prime}$ slabs using the process previously described in $Q A / Q C$.

\section{Short Passivation}

The next step is the Short passivation process which has been previously described in Section 2. QA/QC.

\section{Screen Print Grid Pattern}

In the next step, a silver ink grid is deposited by screen printing. After the silver ink is IR dried, the slabs are stored on racks and ready for further processing. 


\section{Final Assembly}

Once the slabs are patterned, the next fabrication step is determined by the type of module to be built. The Power Plus TM module series is designed for use in large interconnected arrays with power output on the order of $1 \mathrm{KW}$ or larger. These unique modules use a single $1^{\prime} \times 4^{\prime}$ cell to produce an output of approximately IV at 20A. Because large arrays use a large number of these modules, they can be series and parallel interconnected at the module level to achieve the desired array electrical characteristics. Because multiple cell interconnection is not required during module fabrication, manufacturing costs are reduced and the module assembly process is greatly simplified.

To fabricate Power Plus TM modules, $1^{\prime} \times 4^{\prime}$ short passivated slabs which have passed through the scribing and current collection grid deposition steps are applied with buss bars and simply laminated between sheets of protective polymer and installed in support frames.

Other consumer products require small modules with voltage output which will permit their use of battery cilargers. These modules require a more elaborate fabrication process in which strips are interconnected to increase the operating voltage.

All cutting is done along the TCO etched lines to avoid shorting. The slabs are cut to cell strips. Individual cell strip sizes are optimized for the various module designs.

Cells are interconnected to make the cell assembly. The cell assembly is carried out on a specially designed fixture.

The laminating process effectively encapsulates the wired and interconnected strips between polymer sheets for protection against the environment. The exact procedure is somewhat dependent on the r.rray application. A typical lamination process 
involves several layers of polymer sheets--clear on the front side of the solar array and black on the back side. Between the polymers and the assembled cell are EVA and Crane Glass. The EVA is used as a filler since it melts during the heated lamination process and the crane Glass is a fiberglass mesh which allows the air pockets to be removed. After all of the layers are assembled together they are put into a vacuum laminator. Heat and atmospheric pressure are applied in the laminator. After the lamination, the modules are then trimmed to finished size and prepared for module assembly.

Module finishing consists of fabricating an aluminum frame and caulking a trimmed array into the frame. At the back of the module, a junction box is also attached which provides a screw terminal connection to the panei itself. The junction box contains an isolation diode to allow multiple arrays to be interconnected.

Testing and packaging is the final assembly step. A large area pulsed solar simulator (LAPSS) is used to check the current-voltage characteristics of the module and calculate the efficiency. Tested modules are then individually packaged in cardboard boxes, and stored for shipping.

IV. PRODUCTS

ECD and it's subsidiaries produce a full complement of photovoltaic products. Because we use a stainless steel substrate, the modules are uniquely rugged, flexible and light weight.

The Power Plus ${ }^{\text {TM }}$ module, shown in Figure 11, is the world's largest single solar cell. The high yields obtained in the roll-to-roll deposition process allow us to incorporate material directly from the automated solar cell deposition system into the Power Plus ${ }^{\text {TM }}$ module in a single $4^{\prime}$ by $7^{\prime}$ 'sheet. 
The specification chart for Power Plus ${ }^{T M}$ modules used for the PVUSA program (20kw systems at Davis, California and Maui, Hawaii) is attached (Figure 12) and a photograph of the Maui installation is shown in Figure 13. As is shown in this specification chart, ECD's modules have passed all the environmental qualification tests set by PVUSA project. 
A variety of products are produced for various applications, some of which are listed below:

Power Plus ${ }^{\mathrm{TM}}$ Series.

SUNPAL TM line of personal portable power packs which provide 2 to 10 watts of power.

- RL100 TM - 32 watt flexible solar electric module which is lightweight and easy to install.

- R-100 ${ }^{T M}$ - 37 Watt rugged solar electric module.

$6,12,21,33$ Watt Marine modules for marine applications.

- MP-Series portable power packs for remote portable use.

- MPV-3010 units for vehicle battery charging.

- High power portable Porta Volt Series (PV-140 and PV-280). lightweight and highly mobile applications requiring significant amounts of power.

Extra lightweight portable generator (PVL).

Coated Substrate. This is essentially a substrate with the active solar material deposited on it, and because of the possibility of separating solar cell deposition from module fabrication, coated substrate becomes a type of solar cell product in its own right. The coated substrate is processed into the variety of products described in this section. It can be shipped for processing at a local assembly facility near the end user's market. In this way, highly efficient product fabrication strategies may be employed. Currently coated substrates are being shipped from the Troy based manufacturing plant for processing by Suryovonics, ECD's Indian Joint Venture, into P.V. Modules. Accordingly, the technology provides a unique opportunity to establish a large coated substrate processing plant benefiting from economies of scale, to provide an intermediary product to a number of Module Assembly Plants in various locations. 

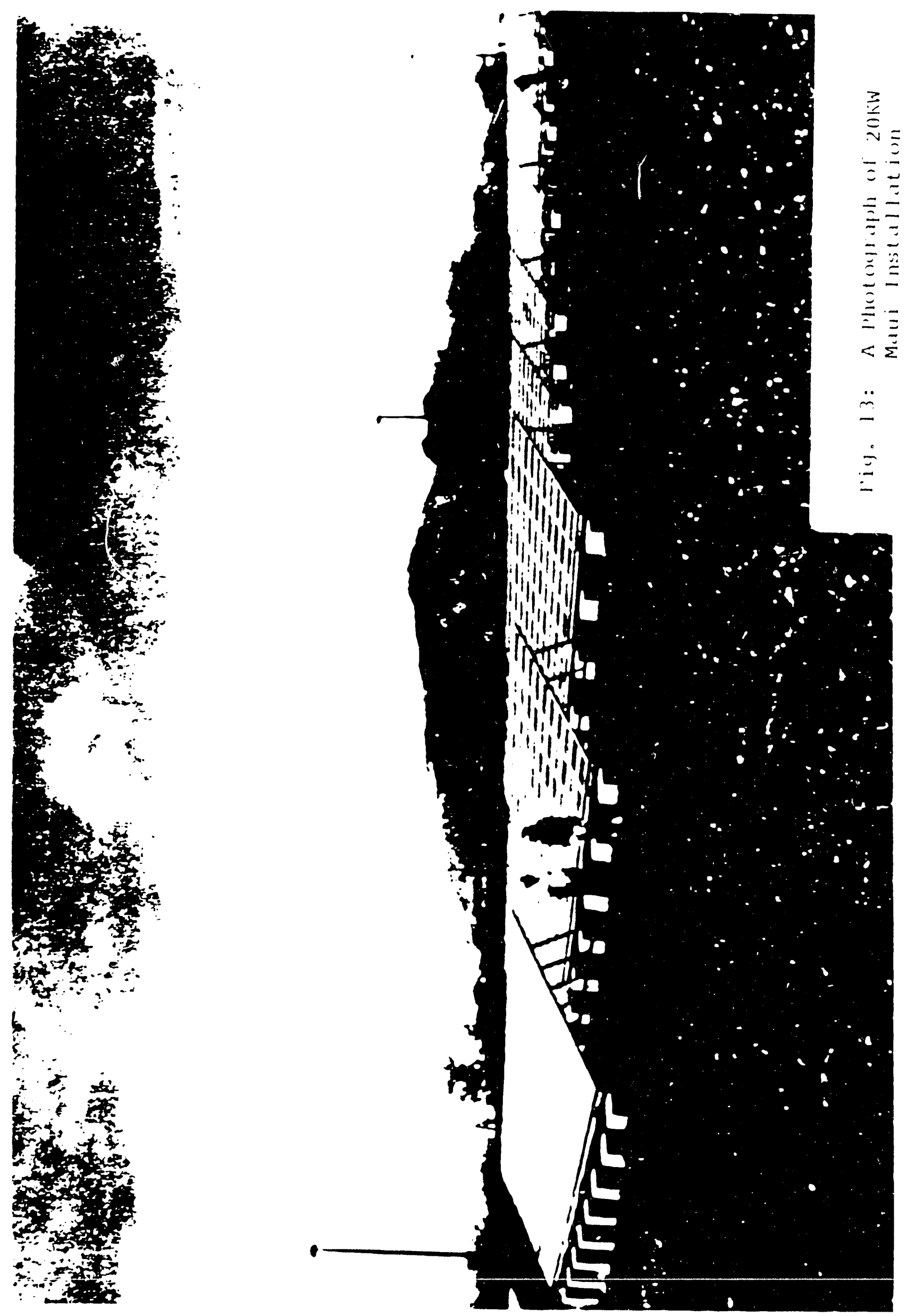
Tandem Junction

Photovoltaic Power Module for

Utflity Scale Applications

Description

The $\mathrm{P} 25$ is a product of ECO's proprietary amorphous silicon alloy, thin film tandem cell technology. Sovonics photovoltaic cells are manufactured by depositing six layers of amorphous silicon alloy materials onto a .008 inch stainless steel substrate in a proprietary roll-to-roll process. The cells are encapsulated in EVA and Tefzel (Dupont trademarks) which serve as protective coatings offering long term resistance to weathering and outstanding mechanical and optical properties. Rated at 25 watts peak power. the P25 consists of a single one by four foot large area amorphous cell laminated into a single low voltage high power module. The P25 has an extruded aluminum frame and exceeds industry standards for structural loading and environmental protection. Specifications and fabrication details are provided below. The P25 POWER PLUS module is backed by a 5 year Limited Warranty.

\begin{tabular}{|c|c|c|c|}
\hline Electrical & Peak & Guaranteed & Environmental Qualification \\
\hline Specifications ( 1 ) & Power & Minimum Power & Tests and Specifications \\
\hline Power & $25 W$ & $23 W$ & $\begin{array}{l}\text { Temperature Range }-40 \text { to } 90^{\circ} \mathrm{C} \\
\text { Wind Loading }>150 \mathrm{mph}\end{array}$ \\
\hline Voltage (Operating, typ) & $1.28 \mathrm{~V}$ & & Hail Impact $>52 \mathrm{mph}$ \\
\hline Current (Operating, typ) & $19.2 \mathrm{~A}$ & & $\begin{array}{l}\text { Hi Voltage } 1500 \text { volts } \\
\text { Temp. Coeff. }-3 \% /^{\circ} \mathrm{C}\left(25^{\circ} \text { Ref }\right)\end{array}$ \\
\hline $\begin{array}{l}\text { Voltage } \\
\text { (Open Circuit, typ) }\end{array}$ & $1.6 \mathrm{~V}$ & & Current (Short Circuit, typ) $24 \mathrm{~A}$ \\
\hline
\end{tabular}

Mechanical Specifications

Dimensions $13.5^{\prime \prime} \times 47.6^{\prime \prime} \times 1.56^{n}$

Weight $\quad 7.8$ lbs

These data represent the performance of modules as measured at their output terminals and do not include the effects of additional accessories such as diodes and cables. The data are based on measurements made at standard test conditions: fllumination $1000 \mathrm{~W} / \mathrm{m}^{2}$ AM $1.5 \mathrm{global}$ spectral distribution cell temperature of 25 degrees $C$.

Fig 12: P25 Module Specification 


\section{govinutes \\ Salursystions}

\section{Ajues Darvz

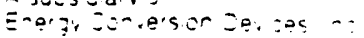 \\ POWER PLUS ${ }^{\text {TM }}$}

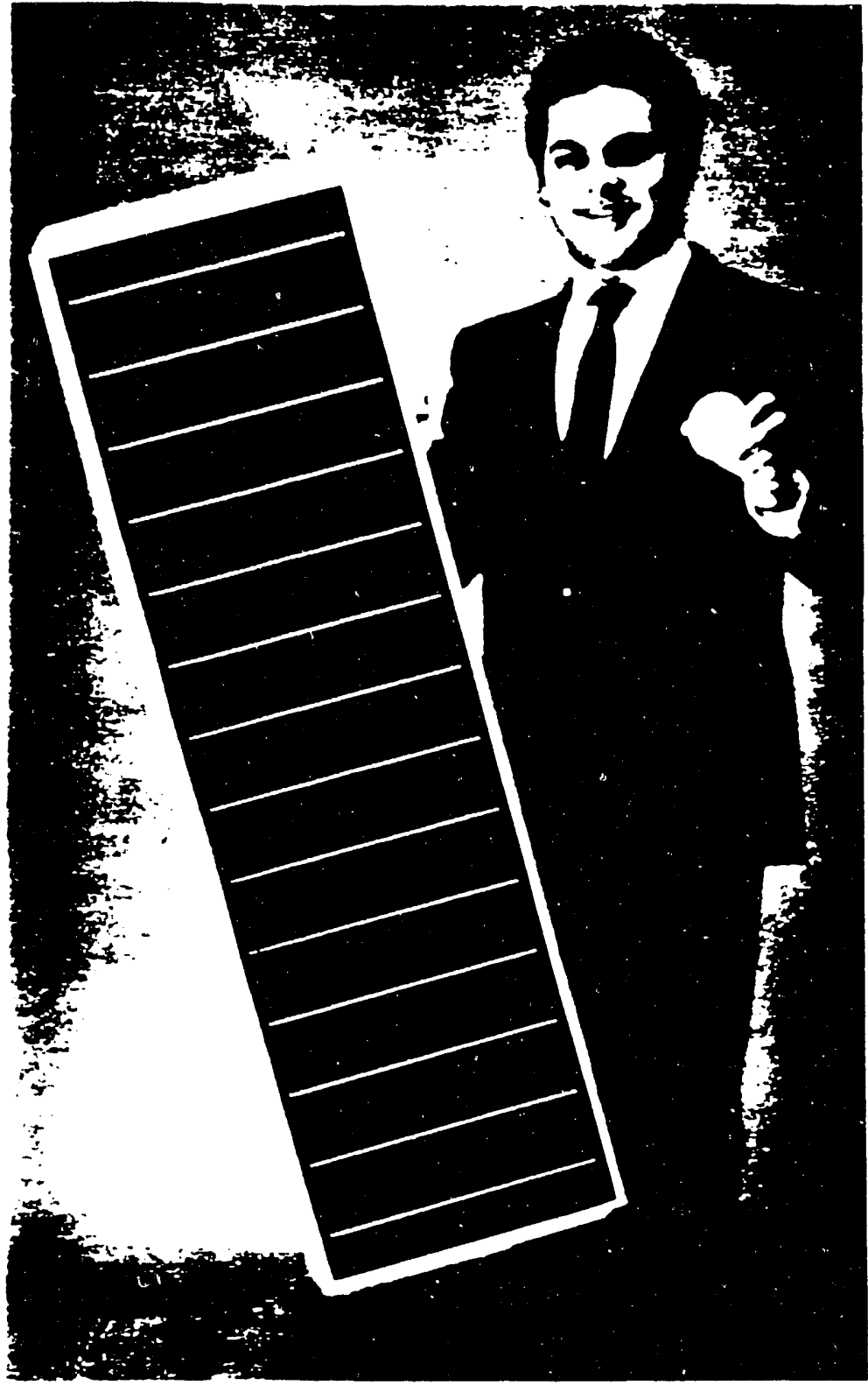

\section{Specifications:}

Power Out-20 watts

Short Circuit Current-21 amps

Open Circuit Voltage- 165 volts

Wind Loading- $150 \mathrm{mph}$

Length-48 inches

Height-1.1/4 inches

Width-13-3/16 inches

Weight-4 $8 \mathrm{lbs}$
Sovonics Solar Systems introduces a new concept in solar module design

The low-cosi POWER PLUS a large-area- $1 \mathrm{it}$ by $4 \mathrm{ft}$-singie-cell solar module

More specifically. POWER PLUS is a polymer encapsulated amorphous silicon alloy thin-film solar cell with a stainless steel substrate

- So like other Sovonics products. It is ight-weight and highly flexible

- Tesis have demonstrated the durability and faultcolerance of POWER PLUS

- And. POWER PLUS like other Sovonics products. is also stable

Unique Sovonics manufacturing technology elıminates the distinciion between a cell and a mod. ule and allows all device interconnections to occur externally at the module level.

The result is a low-cost single-cell solar modulethe largest ever produced - which is many limes larger than the conven. tonal silicon wafer pictured at the left
POWER PLUS Power Generation Application: Include:

- Grid-Connecied Pawr

- Non-Gria Connec:ec Remote Power

- Residential Power

- Agricultural Aodiraturs|

For more information on POWER PLUS and other new generation solar power products contact:

Sovonics Solar Sisiems 1100 West Masie Foa:

Troy. Michigar 48084

Telephone $1313,362.3: 20$

Facsimile 1313 , 362.:.22

Telex 230648

Represented by: 


\section{R100 \\ Photovoltaic Module}

\section{Building Block for Solar Electric Generators}

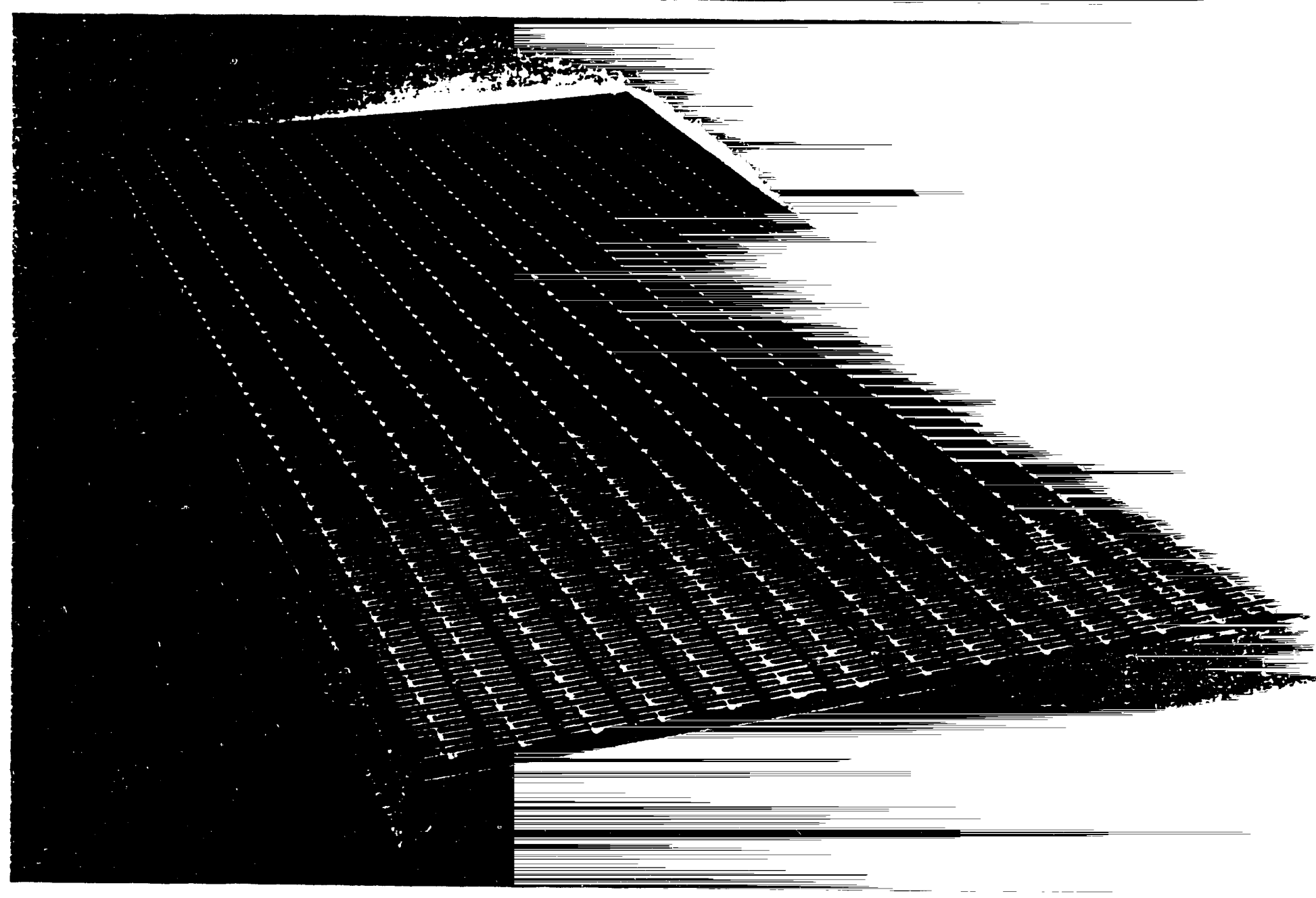

From the research and develooment tacilities or Sovonics" Solar Systems comes the most advanced pnotovoltaic lecnnology avallable. ine result of a long commiment to ceveiooing ine dest material for convening sunlight into electricity.

The Sovonics ${ }^{i \nu}$ R100 pnotovoltaic module is a breakthrough in man's efforts to efficiently capture the energy of the sun. It will pruvide cost-enfective electncity for many years.

The R100 module features thin film, amorpnous silicon solar cells inat establish the standard for amorphous silicon material. Amorphous silicon alloys are deposited in a very inın, continuous film on a flexible stainless steel substrate to produce large area pnotovoltaic devices. Sovonics mocules have nigner cell packing densities than crystalline silicon modules.

A uniform. consistently nign quaity product is assured by the unique. coninuous cell manufacturing process. Sovonics R100 cells are protected by a proven, unbreakable. durable polyvinyl fluoride shell The protecive covering made of Tedlars PVF resists weather and aouse. is flexible, and will not degrade even under severe environmental conditions. This coating has proved reliable in installations in various applications worldwide for more than 25 years.

\section{The Sovonics R100 Module}

- Is a rugged. Igntweignt eleciricity generator

- Features a unique, semi-tlexible mocule consiruction

- Exceeds all US government and European Community module lesis

- Features Sovonics strip cells. large area photovoltaic devices inat establisn !ne standard for amorphous silicon material stability

- Has a frame design that recuces installation costs and ume 


\section{Design Characteristics}

\section{Materials}

The materials used in the Sovonics R100 are selected to be compatiole with the unique cell material The Sovonics strip cell interconnect scheme provides redundant electrical connecirons and outstanding mechanical integrity. The a-Si cells are encapsulated in a proprietary EVA formulation. The materiais in the module package provide an alternative to glass. wnich has been used to support convennonal. íragile. brittle crystalline PV cells.

The A 100 module features a lough. clear protective coating that has excellent resistance to weathering and outstanding mechanical properties. and is inert to virually every agent that defaces or erodes other surtaces and finishes.

\begin{abstract}
Mechanical
The R100 is a rugged. Iightweignt eleciricity generator The dovanced materlals used in ine R100 irake it the tirst semi-rigid Py module The llexiole characieristics of the Sovonics cells provide opuortunities !or design incrovements anc rost savings in the structural supports dne arrays without sacrilicing sirengin Sovorics engineers nave develoded a lignter Nerght module. The electrical junction oox 's secured by boin mechanical and chemical bonas to insure !ong-term integrity.

\section{Electrical}

The Sovonics $\mathrm{R} 100$ module is a 12 voit nominal battery charger it can oe used alone or in an arrav or modules 10 meet your power requirements. The Rroo leatures a hignly rellable junction box -interconnect design that requires no special tools in the field. By-pass diodes at the cell level assure protecition in the event of partial shading of the module.
\end{abstract}

\section{Environmental}

The Suvonics Rio0 is designed to hign standards and has passed more demararig tests than those of ine $U S$. government anu Eurooean Community laooratcries The components are engineered io work together to insure that ine R!co wil oroyse years ot relladie power in any iocation

The outer snell teatures a clear Teclar. PVF cover and a wnie Tealar" PyF oack sheet These layers assure that the Rios monule will not break on impact. shatter or tear. and will not oecome oritle or crack when exposed to extremes of temperatures or deteriorate when exposed to ultraviolet racialion. Identical coatings. proven commercially to be weather resistant since 1962. nave survivec sancclast tes!s and ivo decades of exposure to desen enirion. ments. The coating withstancs corrosive conditions such as acic rain and aiso commercial cleanıng açents

\section{Specifications}

\section{Dimensions:}

Length

Width

Hergnt

Weignt:

Power:

Power output

Open circuil voltage

Short circuit current

Winc Loading:

Battery Chargıng Point:
$119.5 \mathrm{~cm} \pm 0.2 \mathrm{~cm}$ (47.05 inches)

$59.2 \mathrm{~cm} \pm 0.2 \mathrm{~cm}$ (23.3 inches)

$4.4 \mathrm{~cm} \pm 0.1 \mathrm{~cm}$ ( 1.7 inches)

$5.4 \mathrm{~kg}(11.9 \mathrm{lbs})$

32 watts $\pm 10 \%$ @ AM 1.5. $100 \mathrm{~mW} / \mathrm{cm}^{\prime}$ at $25^{\circ} \mathrm{C}$

$22 \mathrm{~V}$

$2.5 \mathrm{~A}$

$240 \mathrm{~km} / \mathrm{hr}$ (150 miles $\mathrm{hr})$

2.15 amps at 14 volts

\section{Represented by:}

Werrenty

The intormation recommenctations zno odininns set entin in ins

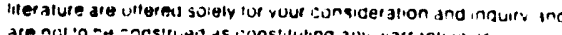

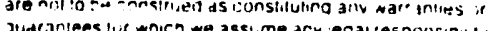

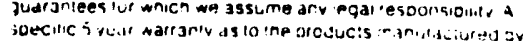

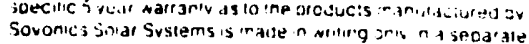

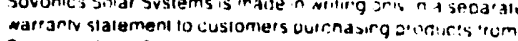
Sovunics Solar Sysiems 


\section{Sovonics Power Series: Building Blocks for Solar Electric Generators}

- The "POWER PLUS:" a new concept in high performance solar module design.
- Reliable, lightweight electricity generators for a broad range of applications.
- Unique power products with thin.film tandem cell structure.

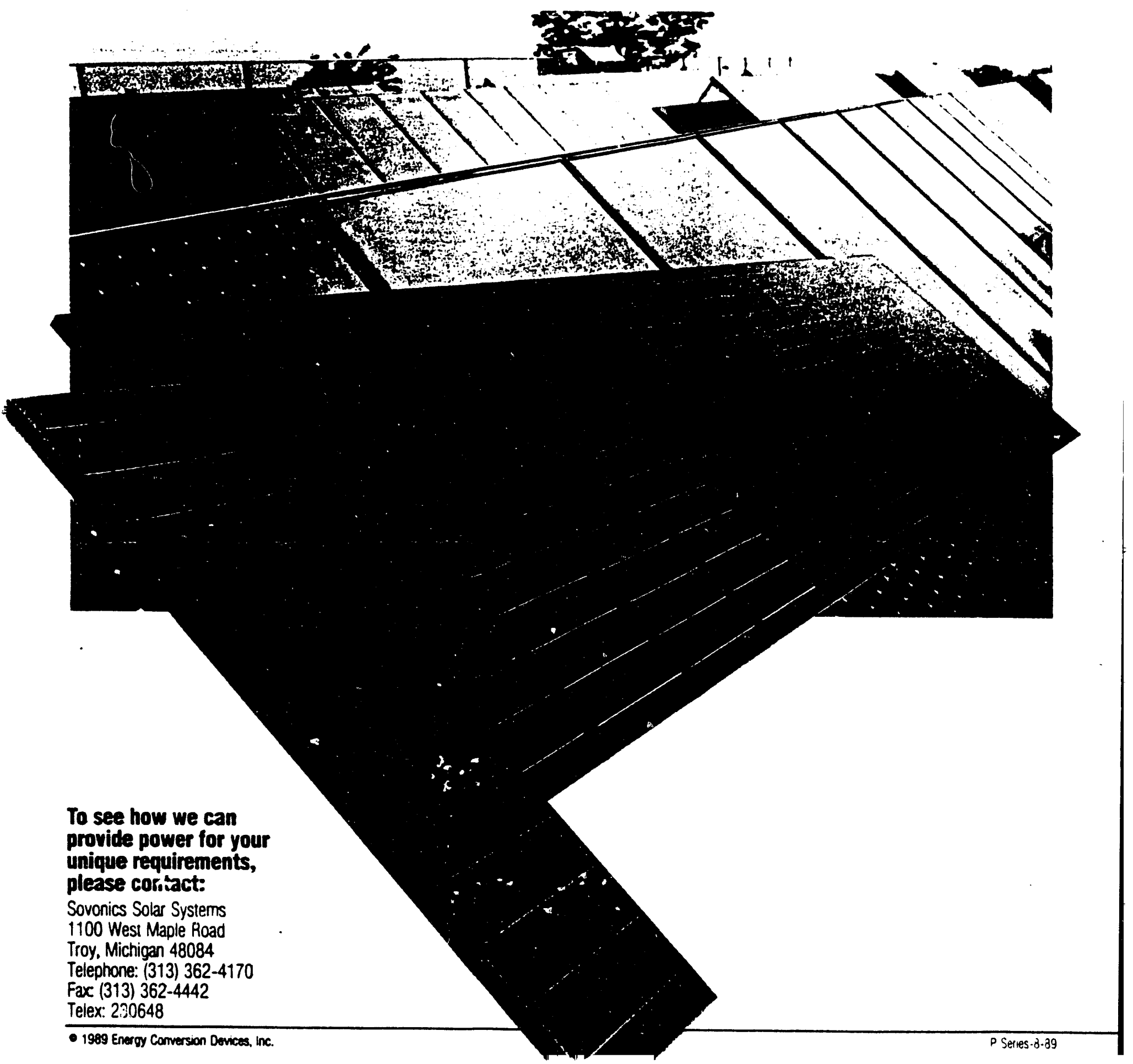




\section{SOVONICS Thin-Film Tandem Products Bring "More Power to You."}

The POWER PLUS series takes advantage of Sovonics solar cell mass production technology, resulting in a new generation of solar modules. Sovonics unique amcrphous silicon alloy tandem solar POWER products, including the Rigid and Laminate series introduced earlier, are designed to provide power where conventional power is unavail. able, unreliable or too costly for applications such as:

- Utility Power

- Commercial and residential buildings

- Village power

- Remote homes

- Telecommunications equipment
- Recreational vehicles and golf carts

- Street and marine dock lighting systems

- Railroad signals

- Security lighting

- Cathodic protection

- Billboard and monument lighting

- Irrigation

\section{Power Plus Series:}

P101-1.2 Volt, 23 Watts*

- A new concept in solar power module design-polymer encapsulated, large area $(1 ' \times 4)$ SINGLE SOLAR CELL on stainless steel.

- Unique product specifications.

- Easy and economical to ship and install.

- Designed for larger power applications.

- Lightweight and durable module.

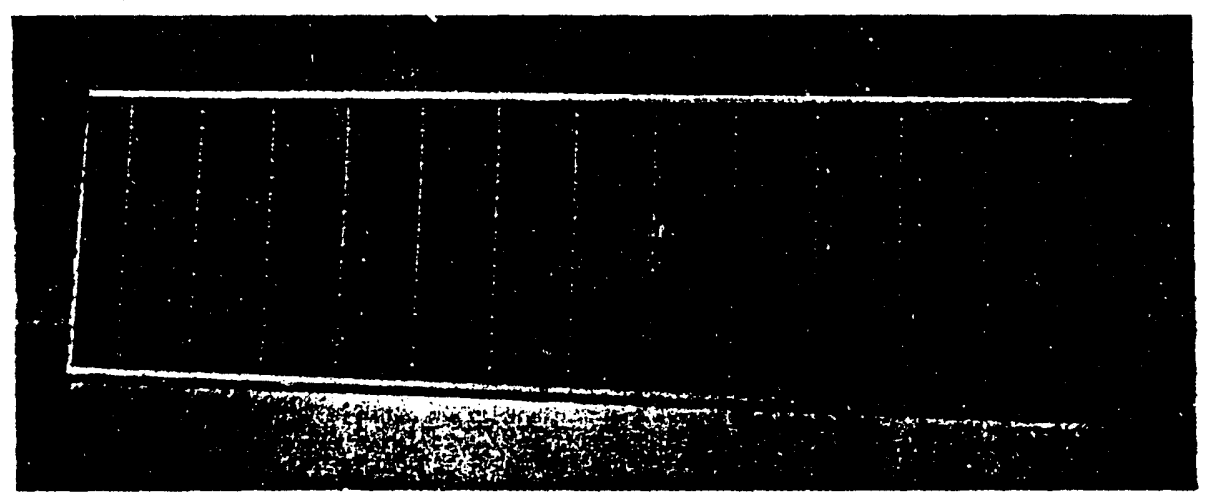

\section{Battery Charging Series: R100-16 Volt, 37 Watts* P201-16 Volt, 23 Watts*}

- This product serıes combines light weight and durability with an extruded aluminum frame designed for strength and ease of installation.

- Designed for battery charging systems.

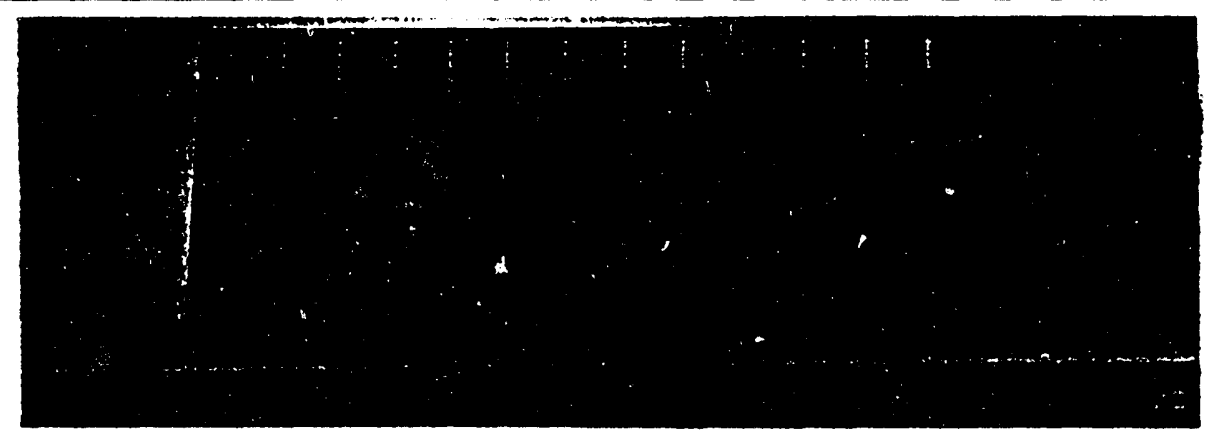

\section{L-(Laminate) Series: PL201, RL100 \\ - Laminate version of P201 and R100 modules.}

- Highly flexible and durable power module. - ideal for custom engineered applications.

- Easy to mount on curved surtaces.

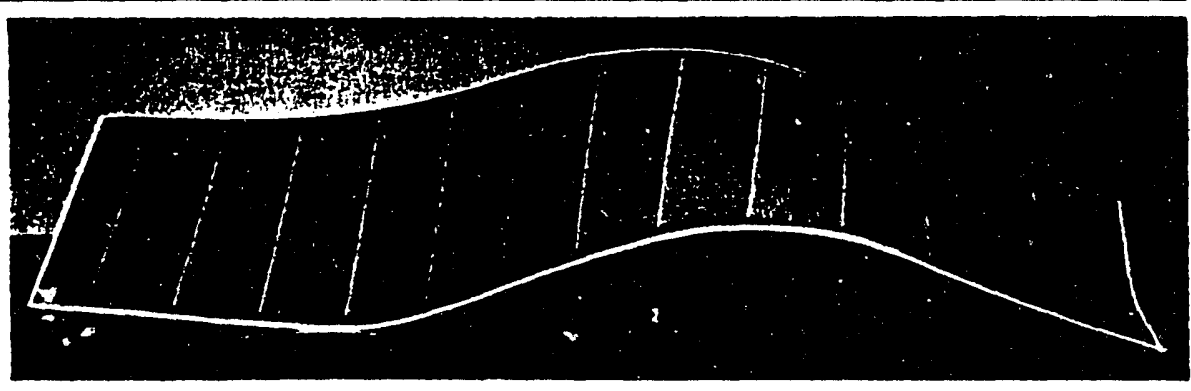

\section{PV System/Product Accessories}

Complete PV systems are available for any application. A variety of product accessories also exist lor Sovonics modules, including mounting structures, wires and cables, connectors and convertors, batteries and regulators.

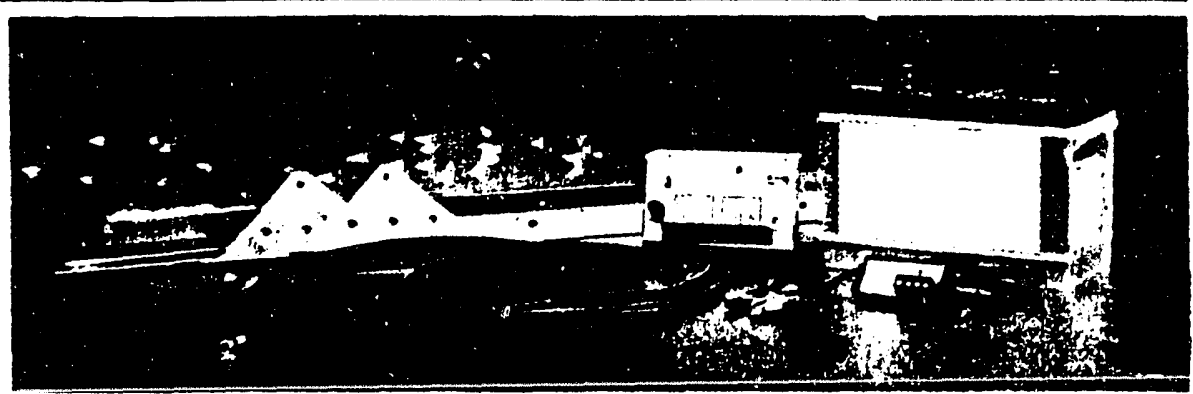




\section{R-Series Structural Support System}

The Sovonics "9-Senes siructural support system is soecially designed to reduce installation ime and cost. Arrays of any number of Sovonics: $\$ 100$ solar modules can be easily assemoled in the field by one serson. Strong, igntwergnt and ourade. the soivcaroonate irames of the individual nocules orovide structural strength tor the array and eviminate ine need for neavy. sumbersome. metal iramıng.

Mechanied

The Sovonics 8100 modules amploy glassilled. loamed porycaroonate suodort 'rames. with sotar cell suostrates sealed to the rames with ruoder gaskets. Lugntweight and semi-flexible out rugged ine modules are self-suodoring and are simory colted ogether to create wo-module arrays. 3acker Jars of not-clo galvanized steet are zcced to inree and four nooule arrays 10 naintain sice-oy-sice alignment of the nodules for maximum eiticiency of energy sollection.

\section{Emvironmenty}

he tootpacs and legs are mace of lignt. strong and corrosion-resistam 6061-T6 aluminum. The oorts. vasners and nuts

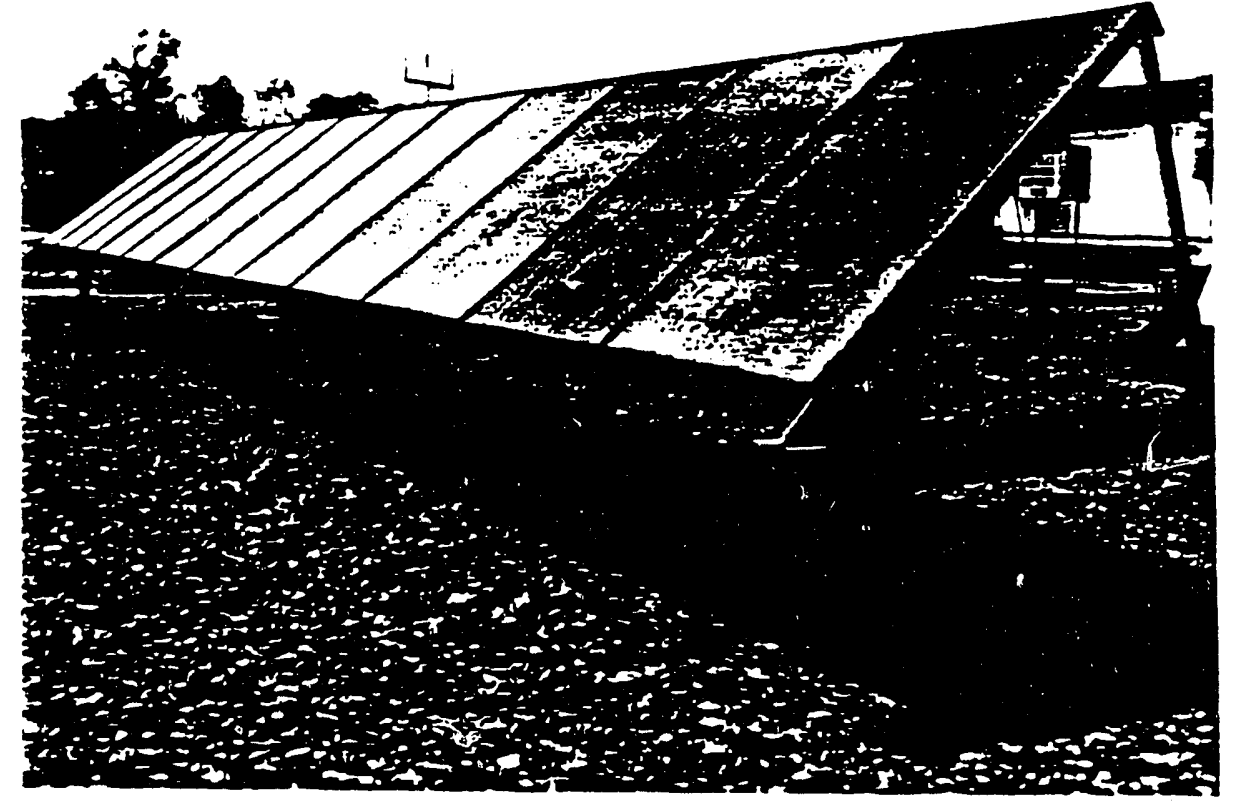

equired for assemoly are stainiess steet

The R-Senes supDor system nas been extensivery tested. Doth oy dead-ioad tests uo 10 mice the design load and oy fatigue iests of the assemoled siructures un 10 10.000 rultitoad cycles of 20 pouncs per square foot loading from both sides.

\section{Electried}

One Sovonics R100 mocule is a :2-vcit nominal battery cnarger. and can ve isec alone for that ouroose. -igner voltaçe and/or sower iequirements are servec ov arrays of mocules interconnecied to neet suecitied load demands. Elec:ncai unc:ion

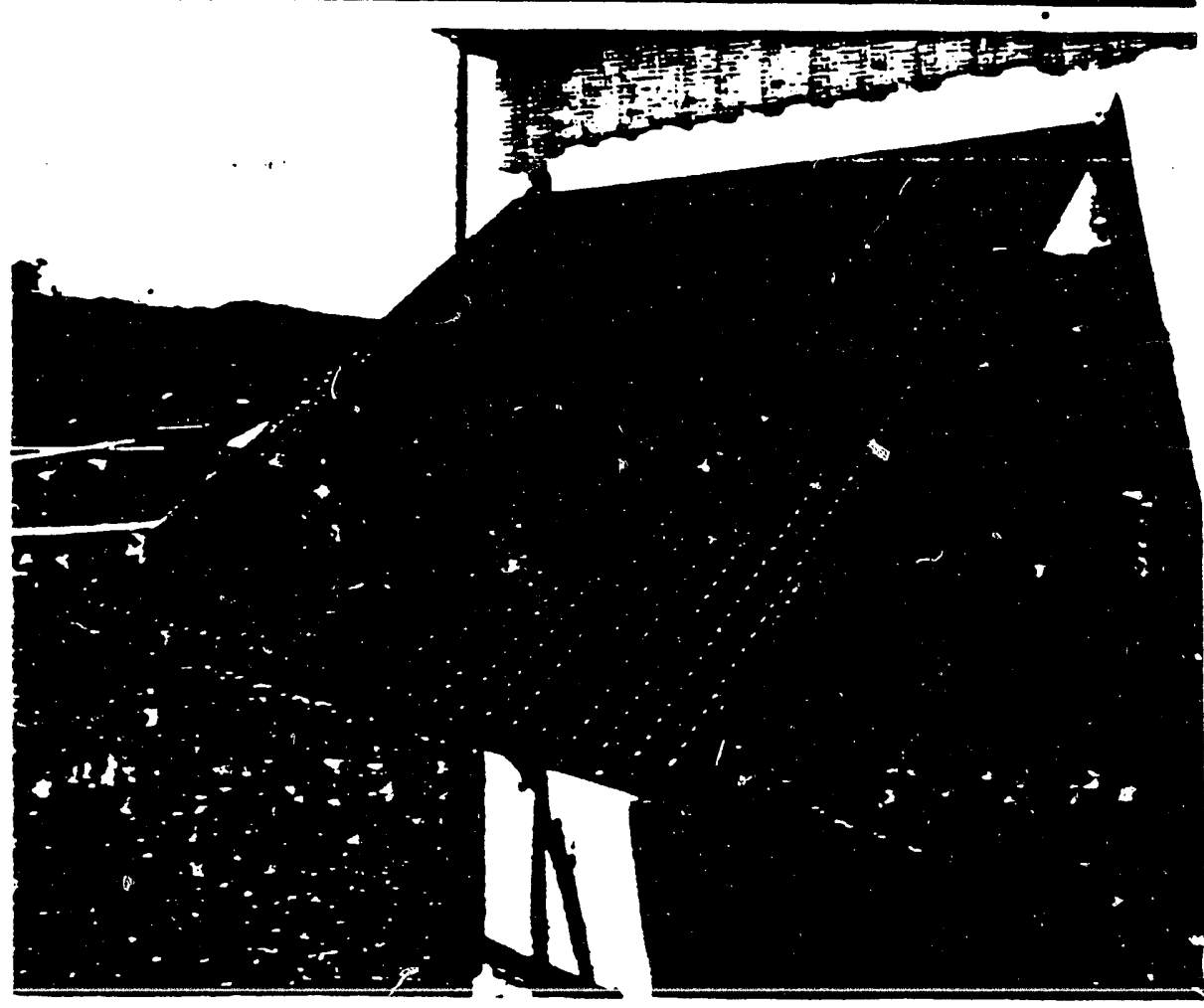

soxes. integral :0 each mocule. srcvice a sare. relladie electrical intercinnec: Ternco that requires no soecial :ools.

\section{Recurn}

- Universal design allows arraying anv number of mocules

- Consists of inree components

- Leg

- Footoad

- Backer Bar

- Modular building docx design ulilizes starter and adomion assemolies

- Unique. semi-flexibie stucrure tolerates bending and mounting misalignment

- Is adaptable to any structural foundation ar any angle

- Withstancs severe environmental concitions

- Provdes standard arraying angles tom $0-90^{\circ}$ in $5^{\circ}$ increments (finer adjustmenis are possible oy varying footbad soacing)

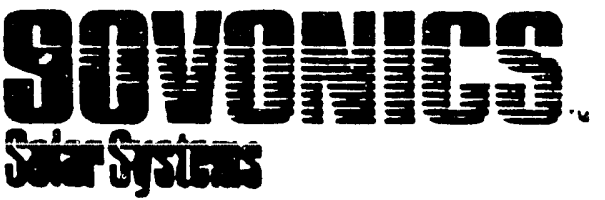




\section{Panel and Arroy Aceambly}

- wo module arrays are created oy colting the irames of the modules logetner. sice. jy-sice. :o torm a iwo module panel. Then :he tootoads and legs used to mount all arrays on vanous foundations are antacned. - hree and four module array panels are 7etd in alignment oy metal strnos called sacker vars. volted to ine upper and lower ends of the module trames.

Larger arrays arn created by accing one :o four module oanels to the initial starting assemoly. Structural comoonent quantities are requced in acdition assemblies by snaring with those in adacent panets.

- Five footpad noles provide mounting lexioulity

- Alternate footoad soacing is oosside oy rotating rooroad

- Module daner ac:s as automatic :00toad zlacement :emolate

- Legs can ce cut :0 engrn in ileta for orcoer :ilt angle
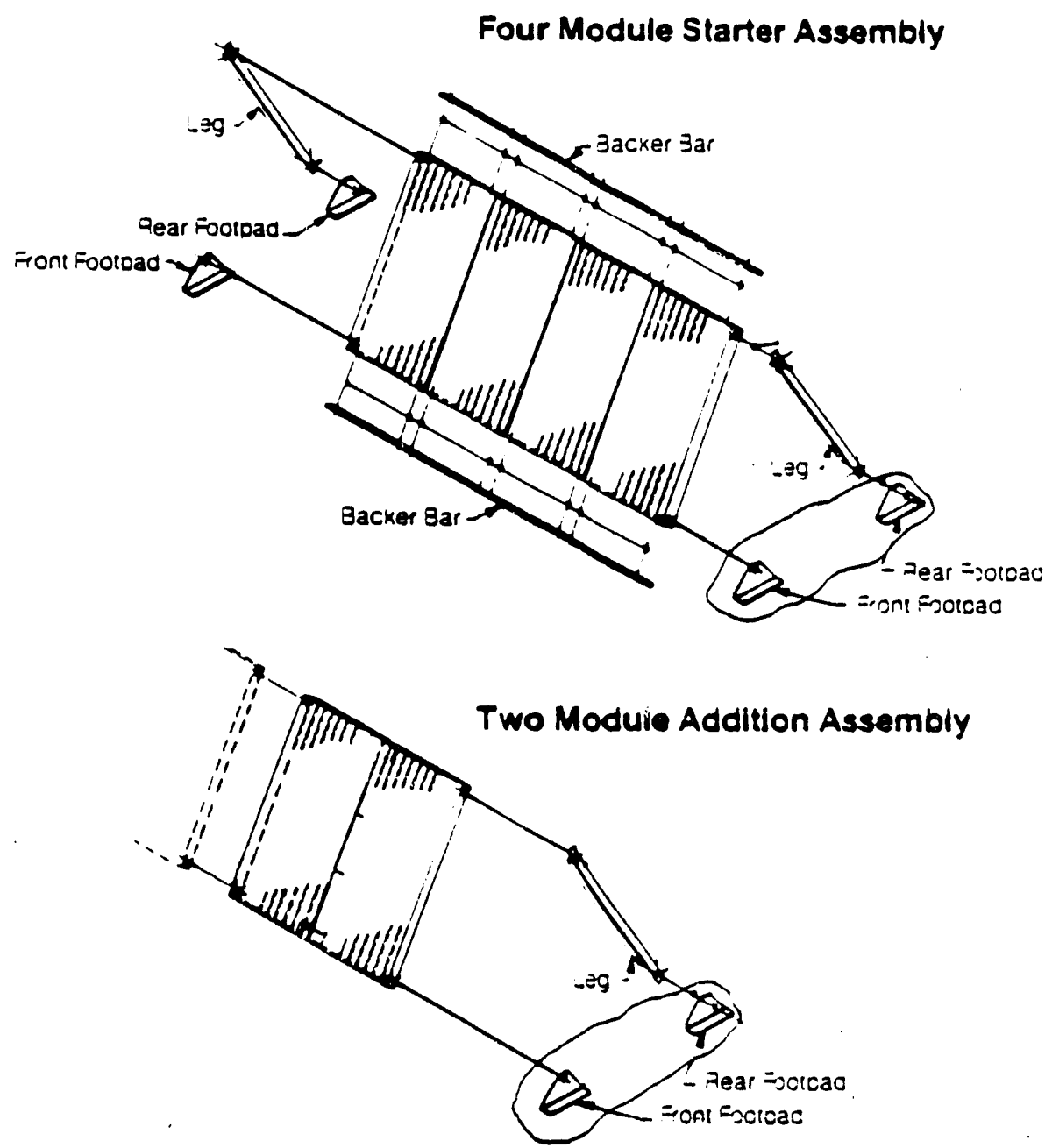

\begin{tabular}{|c|c|c|c|c|c|}
\hline I Penet Starter KIt & & \multicolumn{4}{|c|}{ Number of Mocules } \\
\hline Shioping net weignt & $\begin{array}{l}\text { Ibs. } \\
\text { (kg.) }\end{array}$ & $\begin{array}{c}19 \\
(8.64)\end{array}$ & $\begin{array}{c}33 \\
(15.0)\end{array}$ & $\begin{array}{c}67 \\
(30.5)\end{array}$ & $\begin{array}{c}30 \\
(36.4)\end{array}$ \\
\hline $\begin{array}{l}\text { trray iengtn. } \\
\text { ongest dimension }\end{array}$ & $\begin{array}{l}\text { in. } \\
(\mathrm{cm} .)\end{array}$ & $\begin{array}{l}26 \% \\
(68)\end{array}$ & $\begin{array}{c}50 \% \\
(127.6)\end{array}$ & $\begin{array}{c}73 \% \\
(181.0)\end{array}$ & $\begin{array}{c}97 \\
(246.4)\end{array}$ \\
\hline $\begin{array}{l}\text { Foundation oolts. } \\
\text { center to center spacing }\end{array}$ & $\begin{array}{l}\text { (n. } \\
(\mathrm{cm} .)\end{array}$ & $\begin{array}{c}23 \% \\
(59.4)\end{array}$ & $\begin{array}{c}46 \% 4 \\
(118.7)\end{array}$ & $\begin{array}{c}70 \% \\
(178.4)\end{array}$ & $\begin{array}{c}93 \frac{1}{2} \\
(2375)\end{array}$ \\
\hline
\end{tabular}

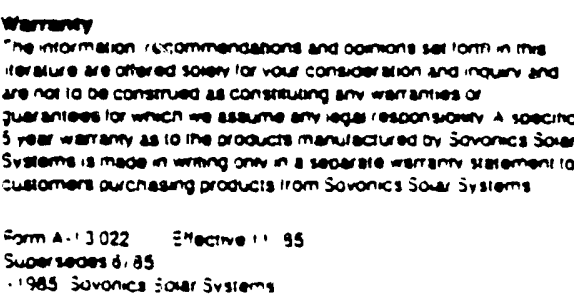




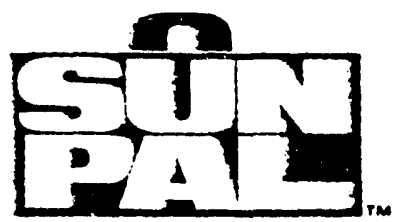

By Sovonica Solar Systems

\section{PORTABLE SOLAR ELECTRIC GENERATOR}

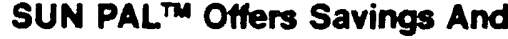 Convenience Year Round}

The SUN PAL ${ }^{\top M}$ line of portable solar electric generators from Sovonics Solar Systems provides free electric power for outdoor use. It is an extremely versatile power supply, capable of powering electrical devices, from radios and televisions to $C B$ radios and video equipment. SUN PAL also allows you to use the sun to charge rechargeable batteries, including large 12 volt automobile and marine batteries as well as smaller batteries.

SUN PAL is affordable. It generates electricity outdoors without adding to your utility bills or running down batteries. SUN PAL's photovoltaic cells convert light directly into electricity for DC power without noise or pollution.
SUN PAL represents a breakthrough in solar technology that allows unique portability. Compact, light, flexible, and rugged, SUN PAL is ideal for taking to the beach, when camping, or out on the water. Any SUN PAL model can be stored easily in a RV, small aluminum boat, or even in a backpack. SUN PAL's flexibility and the inclusion of grommets into the design enable easy adjustment to achieve the best angle to the sun for peak power.

SUN PAL models save money by recharging batteries with sun power and by supplementing or replacing nonrechargeable batteries. Sunlight is free. Batteries are not. Depending on use, a SUN PAL can pay for iteself in battery savings alone in just a single season.

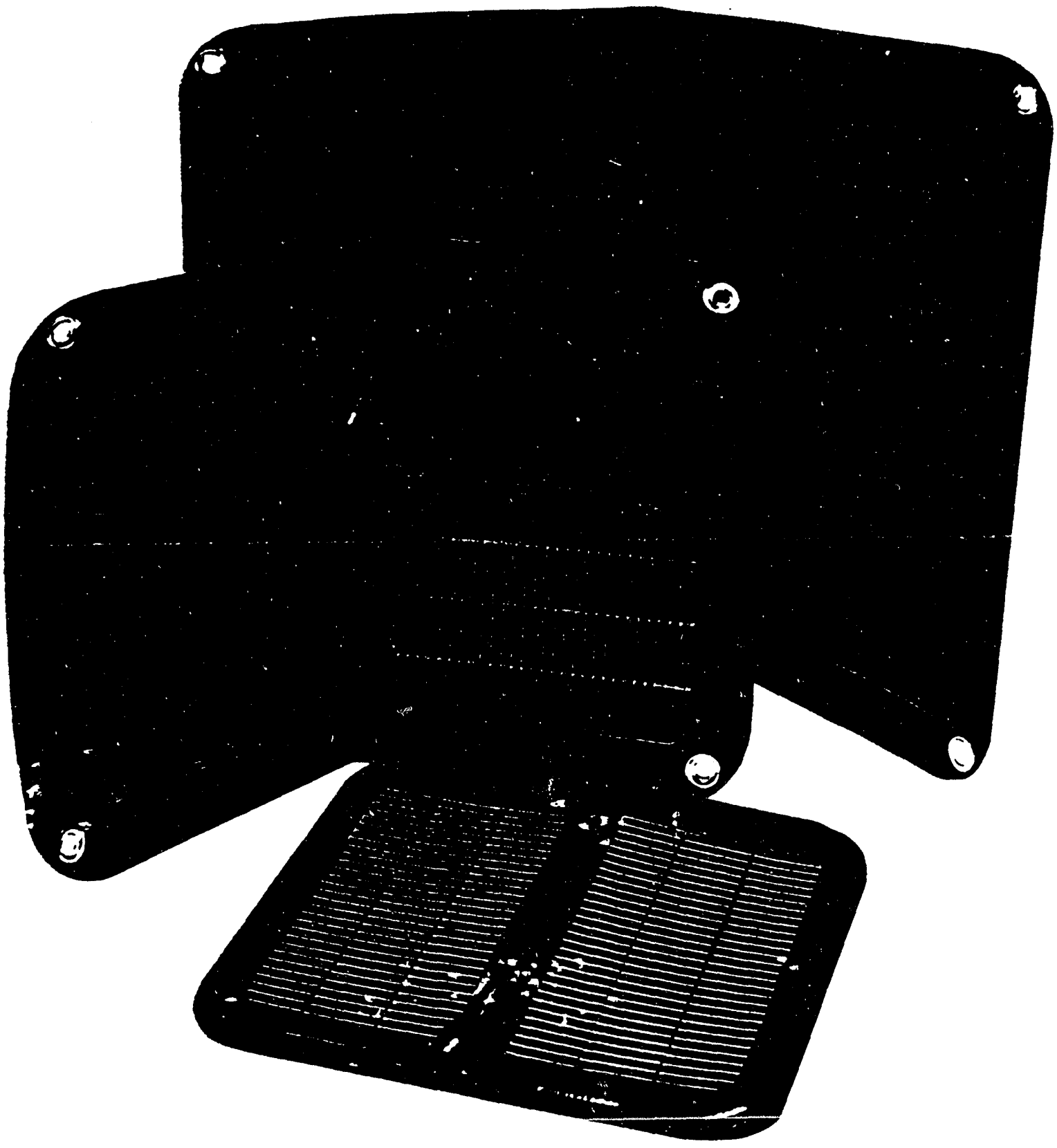




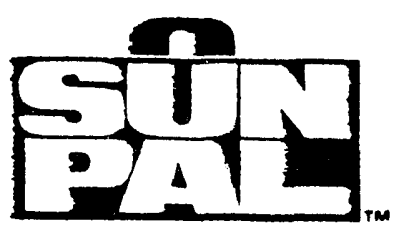

By Sovonicas Solar Systems

\section{SUN PAL 102}

\section{An Inexpensive Solar Generator Featuring Maximum Portability}

The SP 102 when folded takes up less space than a tablet of writing paper . $\left.97 / 8^{\prime \prime} \times 61^{1 / 4^{\prime \prime}} \times 3 / 8^{\prime \prime}\right)$, yet is capable of oowering a portable radio, small cassette player, or other appliance requiring two watts of power or less, at six volts. This nodel is well suited to adults or young seople who spend a lot of time outside istening to music or running another imail electrical appliance, and who are ired of constantly having to replace jatteries.

The SP102 is particularly well adapted for use with a portable six volt, direct current stereo radio.

Like all SUN PAL models, the SP102 is flexible and rugged. It can take a lot of hard use without being Jamaged. And, like each SUN PAL nodel, it folds shut using a velcro tab ather than a breakable metal clasp or iastener.

Each SP 102 comes with a $36^{\prime \prime}$ cord and four polarity reversing $D C$ connectors for small appliances.

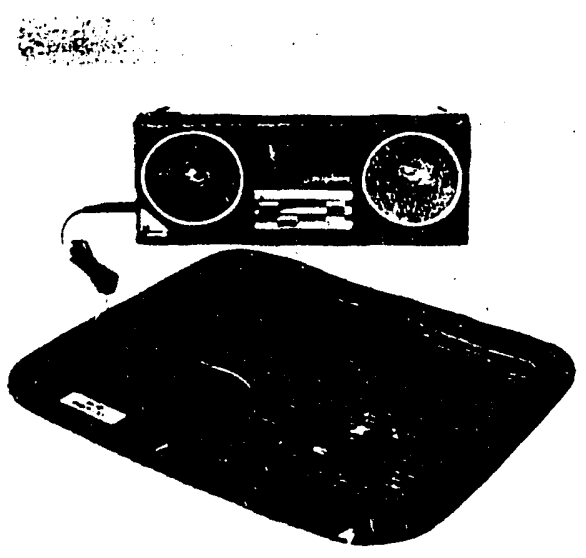

Distributed by
SUN PAL 105

\section{Offers Affordability and Versatility for Beach Lovers, Picnickers, and Outdoorsmen.}

When folded, the SP105 is about the size of a school notebook but thinner $\left(13 \frac{1}{2} 2^{\prime \prime} X 95 / 8^{\prime \prime} X 3 / 8^{\prime \prime}\right)$. When spread open to the sun, it can power a big radio/cassette player, a small television, or a portable computer. In addition, it has been designed (with use of an accessory), to charge 6,9 , and 12 volt batteries for marine, automotive, recreational vehicle, and other purposes.

The SP105's battery charging capability means that it provides not only "fun in the sun," but is a good choice for the prudent outdoorsman.

The SP 105 comes with a $44^{\prime \prime}$ cord, a DC to DC convertor for 6,9 , and 12 volt applications, and four polarity reversing $D C$ connectors.

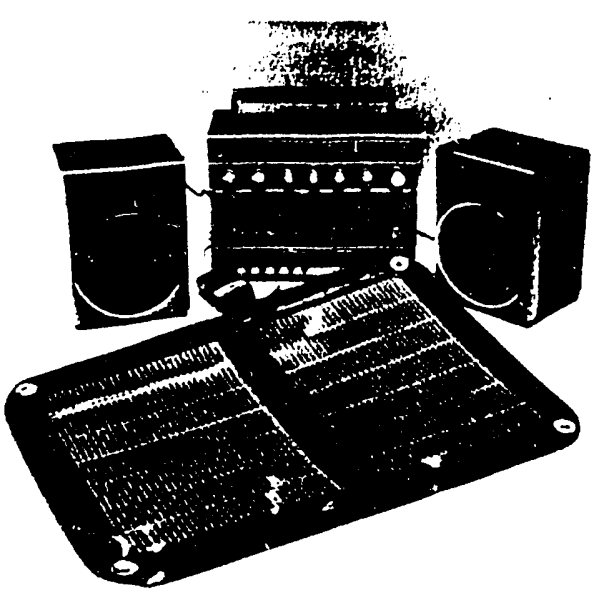

Sovonics Solar Systems is setting up an international system of dealers and distributorsnips. Interested parties are welcome to address inquiries to:

Sovonics Solar Systems, Aitn. James R. Young 1100 West Maple Road. Troy. Michigan 48084 (313) 362.4170
SUN PAL 110

\section{A Powerful Solar Electric Generator for a Variety of Uses.}

Measuring $18^{1 / 4^{\prime \prime}} \times 12^{1 / 2^{\prime \prime}} \times 3 / 8^{\prime \prime}$ when folded, and generating 10 full watts of power on a clear, bright day. the SP110 is the most powerful model in the SUN PAL line. Its extra power generating capability allows the SP110 to perform even on partly cloudy days.

The SP110, like the SP105, has been designed to charge marine. recreational vehicle, and automobile batteries. However, because the SP110 produces a stronger charge than the SP 105, it can greatly reduce the time necessary to recharge a discharged battery. This is an important consideration if your car battery fails in a remote area or if your boat battery suffers discharge out on the water.

The SP110 includes the same accessory package as the SP 105. Please consult the accompanying orcer form for additional accessories available for SUN PAL models.

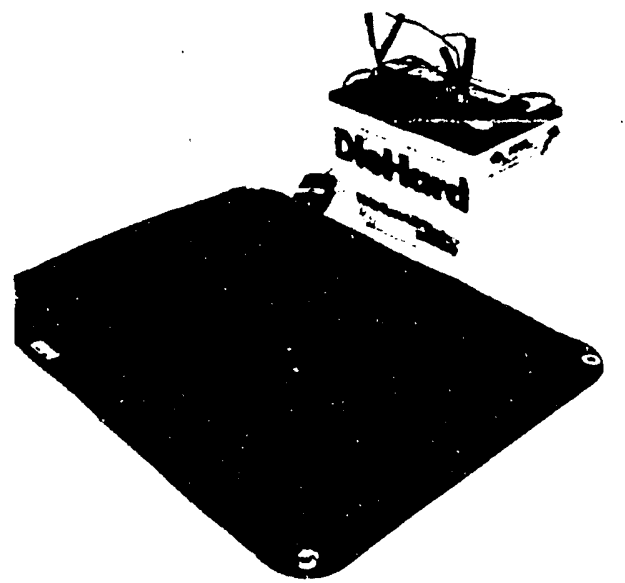



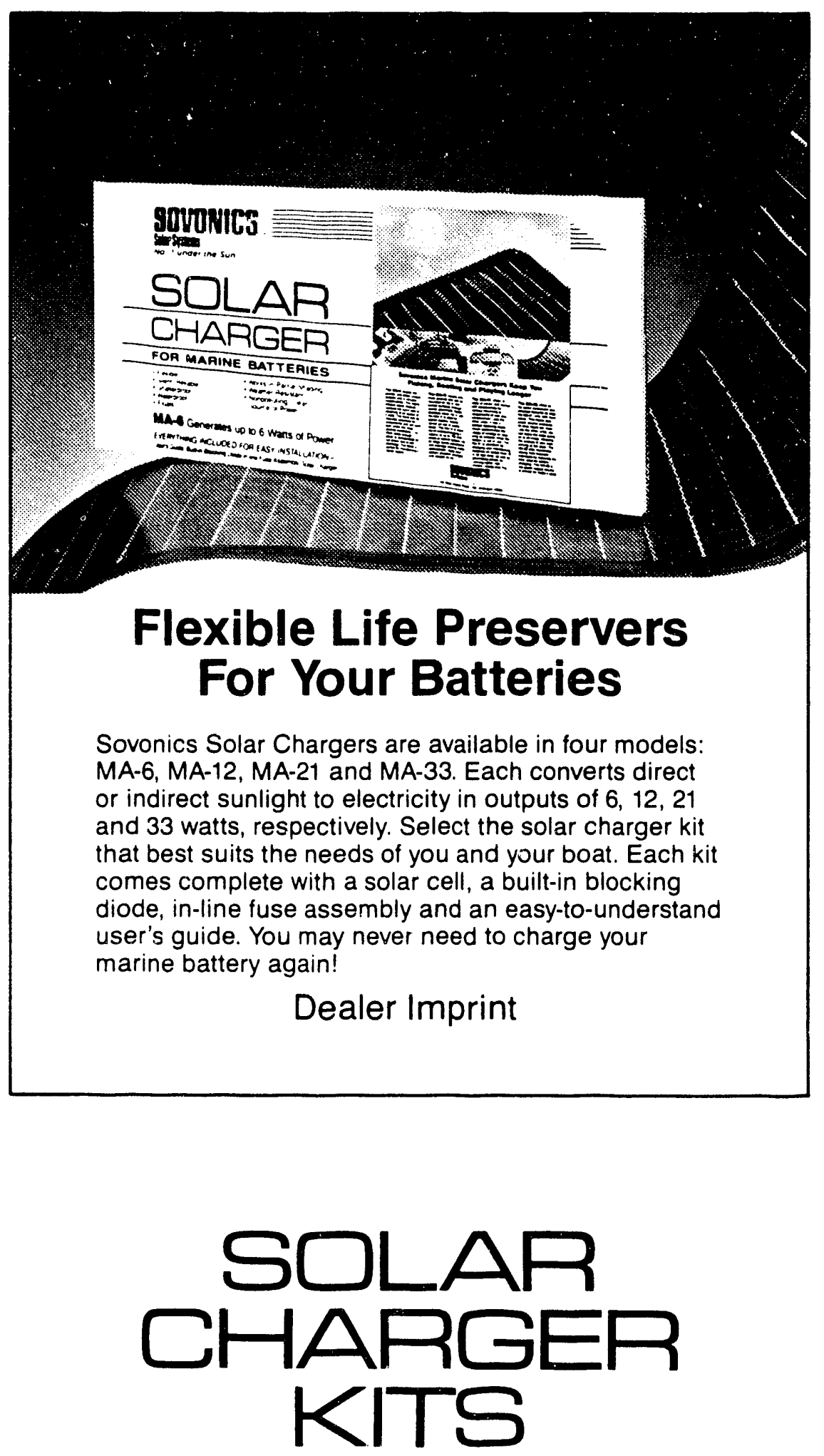

FOR MARINE BATTERIES

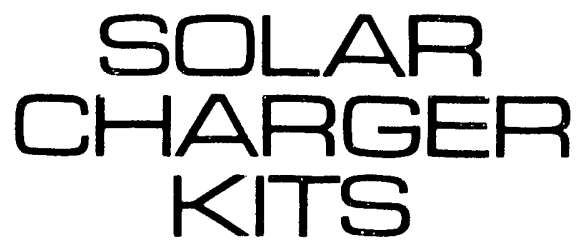

FOR MARINE BATTERIES
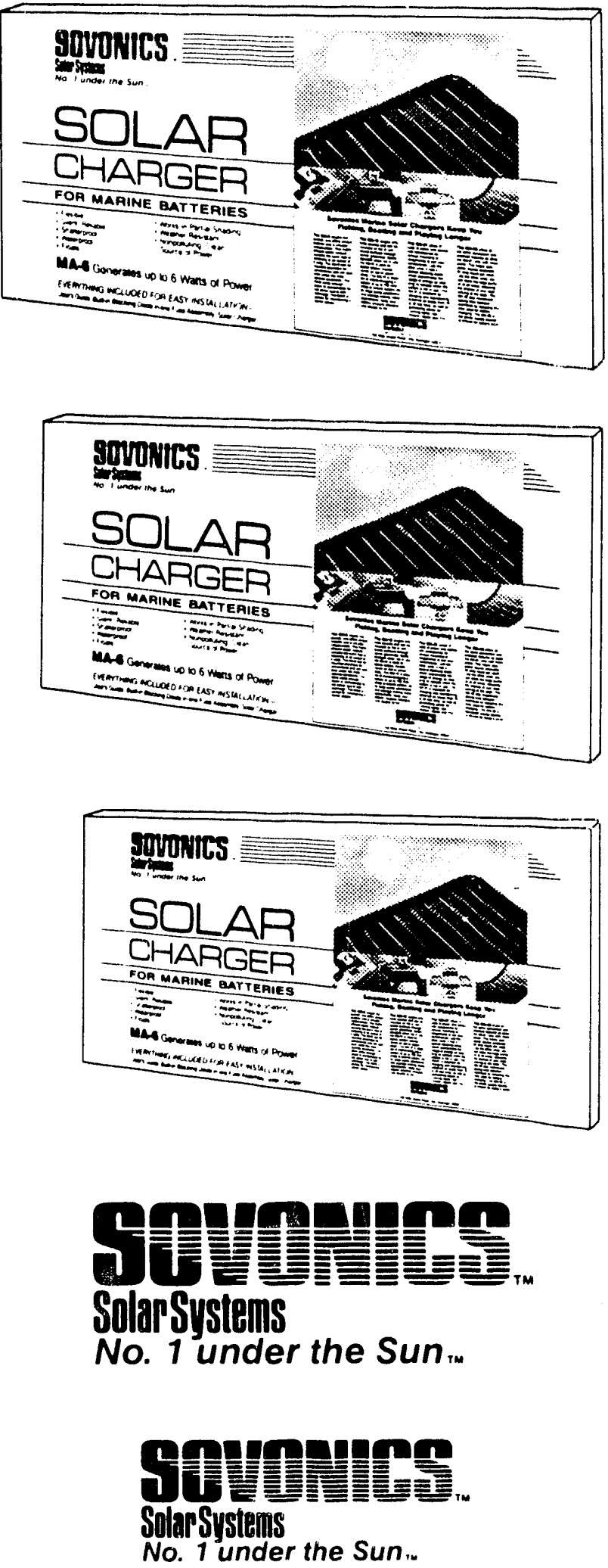

- Flexible

- Silent, Reliable

- Shatterproof

- Floats

- Works in Partial Shading

- Weather-Resistant

- Nonpolluting, Clean Source of Pover 


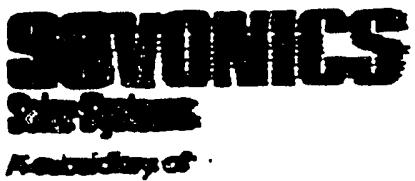

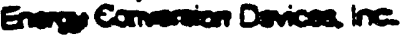

SOLAR ELECTAIC MARINE BATTERY CHARGERS

- rivoner

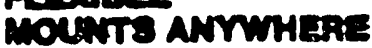

- Pinodre checules Cinctir trom the en

- Rodres minimenenco requinements for on boend emmotore and min encines

- Extend the lin of merina bering

- Kapp the bilor purn coerenting

- Kenp the secties bettory mody to 0

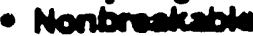

Sovonies Soler Syotom ls Proud To introduce Tho Nemext Developinemt in Sole doetile Cenuraters For Main Uea

These lightweight and flexible modules are virtually indestructible. When mounted on the deck, rootop, or bridge. Sovonics solar generators can bake the abuse of dropped wrenches or pulleys, not to mention occasionally being walked on.

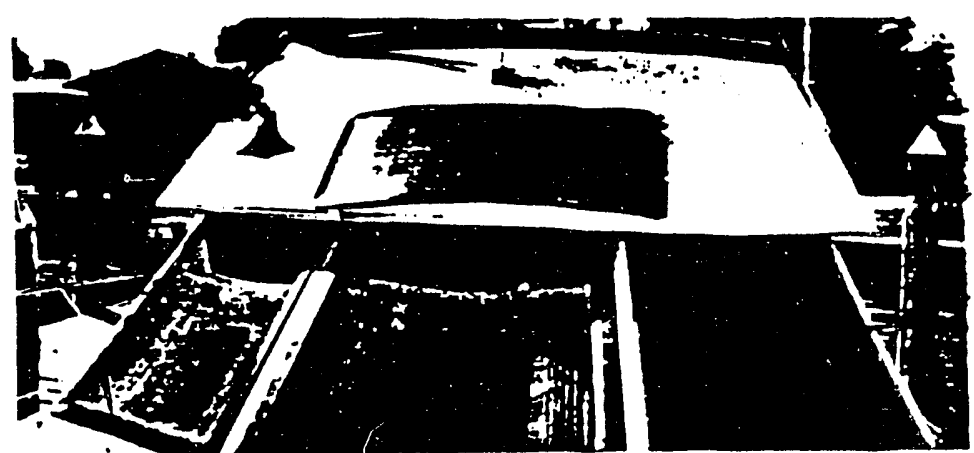

They can be mounted topside or can simply be suspended from the transom, stem, bow railings, over the dodger, or any place they can receive sunlight - even on overcast days.

A small array of these mod. ules offers a reliable substitute for additional gesoline generators, without the problems of maintenence and fuet storage. and for wind generators that are mounted on the spar. just waiting to snag that runaway sail or halyard.
The Sovonics Solar modules offer an importait additional benetit The secunty of a solid state power supply that is more than just convenient when omergencies occur on the high seas.

The Sovonics Solar Systems marine generators offer reliability, durability, stowability, and eese of installation - all without the hassle of moving parts or the confinement of plugging in at dockside.

For more indosmmition on the and ons now genvetion

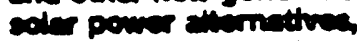
contet your nom sowerico minementerve Systems MA-10 and MA-30

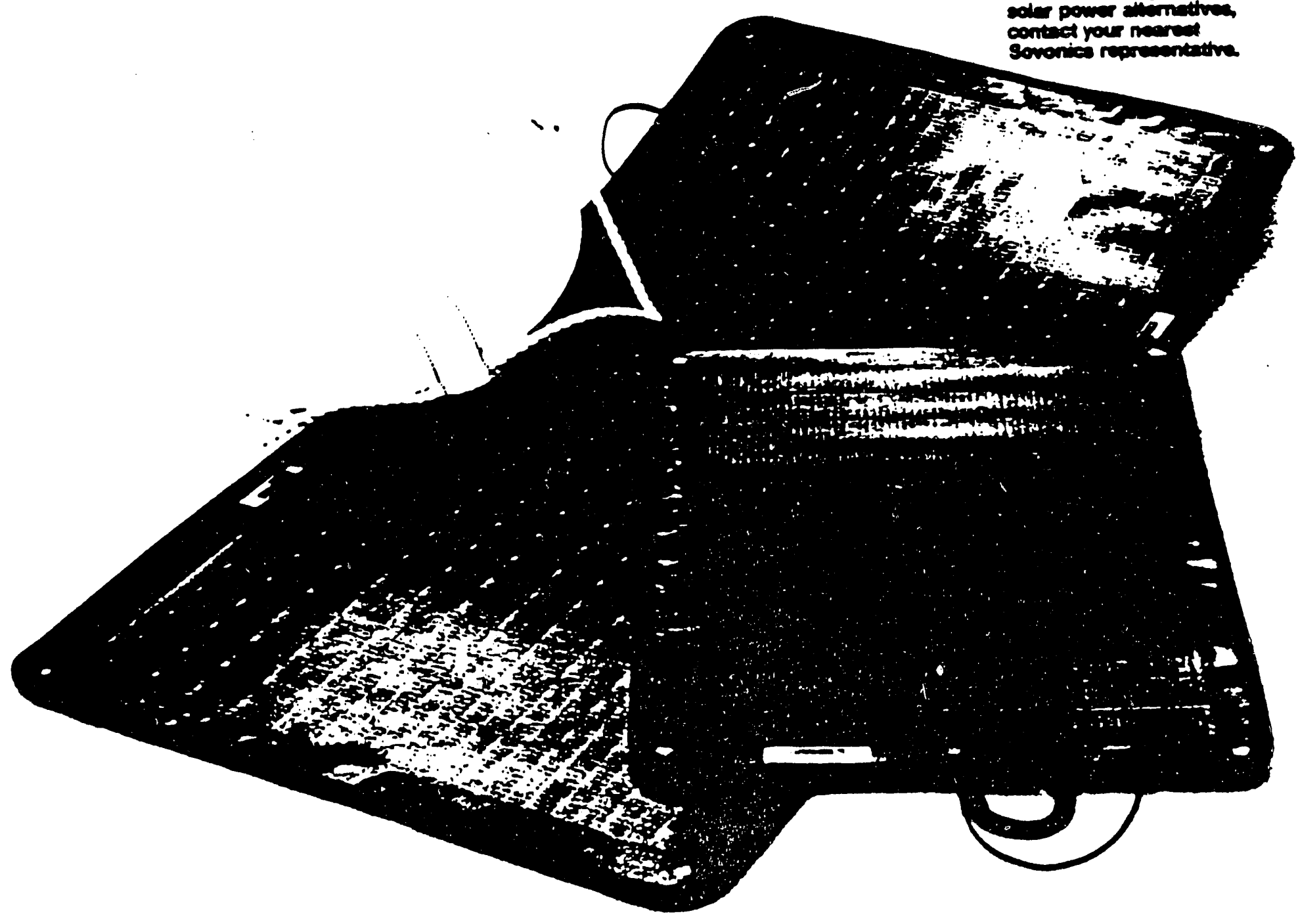


PRELIMINARY SPECIFICATIONS

\section{Sovonica Modules Are Deaigned For Varbue Power Requirementa}

The MA-10 module is perfect for maintaining a starter battery for sail or power boats. It tickle-charges the battery at up to 750 milliamps to compensate for battery self-discharge and occasional bilge pump operations. Keeping a battery property charged can double its. life. Weighing only wo pounds. the MA-10 can be mounted on flat or contoured surfaces through comer grommets, or through the additonal mounting holes provided. This enables a variety of permanent or temporary locations. and can be easily stowed when not in use.

Dimensions:

$\begin{array}{ll}\text { Length } & 24^{\prime \prime}(61 \mathrm{~cm}) \\ \text { Width } & 18^{\prime \prime}(46 \mathrm{~cm}) \\ \text { Weight } & 2 \mathrm{lbs} .(0.91 \mathrm{~kg}) \\ \text { Power output: } & 10 \text { watt } \pm 10 \% @ \\ & \text { AM } 1.5 .100 \mathrm{~mW} / \mathrm{cm}^{2} \\ & \text { at } 25^{\circ} \mathrm{C} \\ \text { Open circuit voltage } & 21.5 \mathrm{~V} \\ \text { Short circuit current } & 0.8 \mathrm{~A} \\ \text { Battery Charging Point } & 0.7 \text { amps at } 14 \text { volts }\end{array}$

The MA-30 module is a heavy duty power source, producing up to 12 amp-hours per day for each module. For the concemed sallor, one or more of these modules is ideal for maximizing sailing time bewween overhauls, and reouc. ing engine time used for battery charging. The MA-30 is thin and flexible enough to offer vitually no obstuction wnen mounted. and at less than 6 pounds, can easily be moved to follow the sun.

Dimensions:

$\begin{array}{ll}\text { Length } & 51^{\prime \prime}(130 \mathrm{~cm}) \\ \text { Width } & 25^{\prime \prime}(64 \mathrm{~cm}) \\ \text { Weight } & 6 \mathrm{lbs} .(2.73 \mathrm{~kg}) \\ \text { Power oulput } & 30 \text { watts } \pm 10 \% @ \\ & \text { AM } 1.5 .100 \mathrm{~mW} / \mathrm{cm}^{2} \\ & \text { at } 25^{\circ} \mathrm{C} \\ \text { Open circult voltage } & 21.5 \mathrm{~V} \\ \text { Short circuit Current } & 2.5 \mathrm{~A} \\ \text { Battery Charging Point: } & 2.15 \text { amps at } 14 \text { volts }\end{array}$

\section{Battery Characteristics For Sovonics MA-10*}

Charging Curnet for 12 Volt Batteries Amp-Hr.JOaY"

\begin{tabular}{|c|c|c|c|c|}
\hline Locenton & Spring & Summer & Autumn & Winter \\
\hline USA (Tenneseo) & 3.4 & 4.4 & 2.6 & 1.6 \\
\hline USA (Minnesota) & 3.2 & 4.2 & 2.0 & 1.4 \\
\hline USA (Massachusens) & 3.2 & 4.0 & 2.0 & 1.4 \\
\hline USA (Gulf Coast) & 4.0 & 5.0 & 3.2 & 2.2 \\
\hline USA (Calitomia) & 4.8 & 5.7 & 3.5 & 2.5 \\
\hline Westem Europo & 3.2 & 4.2 & 2.2 & 1.2 \\
\hline Mediterranean & 4.8 & 4.8 & 4.4 & 2.8 \\
\hline
\end{tabular}

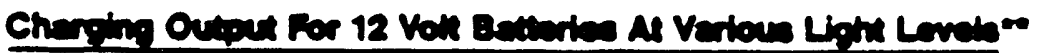

In

Bright Sun ( $\left.100 \mathrm{~mW} / \mathrm{cm}^{2}\right)$

Sunny ( $\left.90 \mathrm{~mW} / \mathrm{cm}^{2}\right)$

Party Cloudy $\left(60 \mathrm{~mW} / \mathrm{cm}^{2}\right)$

Cloudy $\left(20 \mathrm{~mW} / \mathrm{cm}^{2}\right)$

Heeny Couds (10 $\left.\mathrm{mW} / \mathrm{cm}^{2}\right)$

\section{Charing Cuman (ma)}

700

630

412

132

66
Mar Power (Watts)

10.0

9.0

5.9

1.9

0.9

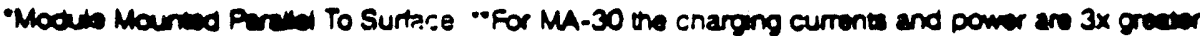

Reprosenned Oy. 


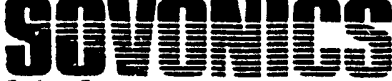

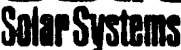

A subsidiary of

Energy Conversion Devices, Inc.

\section{THE MP-3010 PORTABLE SOLAR ELECTRIC GENERATOR/BATTERY CHARGER}

\section{Lighten The Load}

The MP-3010 from Sovonics Solar Systems is a flexible, field rugged, highly portable generator which converts sunlight to electricity. It powers rechargeable batteries in the field and eliminates the need for spare primary batteries and handcrank generators by providing 30 Volts $d c$ with up to $350 \mathrm{~mA}$. A portable electric power system consisting of the MP-3010 and a rechargeable battery will help lighten the load when used with field tactical systems for communications and a variety of other needs, especially on long-term missions. The MP-3010 can also be used to power radios and other appliances directly.

\section{Charge Field}

Rechargeable Batteries For Radio Systems

The MP-3010 has a high power output of up to 10 Watts at 32 Volts. It has a built-in blocking diode to prevent battery discharge at night. The MP-3010 is designed to charge batteries such as the BB-542, BB-590 and others to maintain a charge condition with the radio operated in a 10:1 receive-to-transmit duty cycle. Full recharge of the BB-590 can occur in as little as 6 hours. This capability makes the MP- 3010 valuable for use with military and other special communication systems.

\section{Shatterproof, Rugged, Damage-Resistant}

The MP-3010 is a unique product that takes advantage of proprietary technology, in which amorphous silicon alloys are deposited in thin film layers on a flexible substrate. The MP-3010 is lightweight, portable, tough and non-breakable. Furthermore, the MP-3010 is bullet tolerant - in most cases it continues operating even after being pierced by a bullet.

\section{Easy To Deploy}

The MP-3010 can be deployed rapidly and easily to take maximum advantage of the sun. Two or more MP-3010 units can be ganged in parallel by means of an optional wire harness to provide power for larger systems.

\section{Silent And Non-Detectable}

The MP-3010 is camouflaged when deployed and emits no noise, heat or other characteristic signature. The front panel is dark colored with a non-reflective surface.

The outer covering is a weather resistant nylon fabric in Camo OD or other colors.

\section{Available Now}

For additional price and technical information

\section{contact}

Sovonics Solar Systems 1100 West Maple Road Troy, Michigan 48084 Telephone (313) 362-3120 Fax (313) 362-4442 Telex 230648

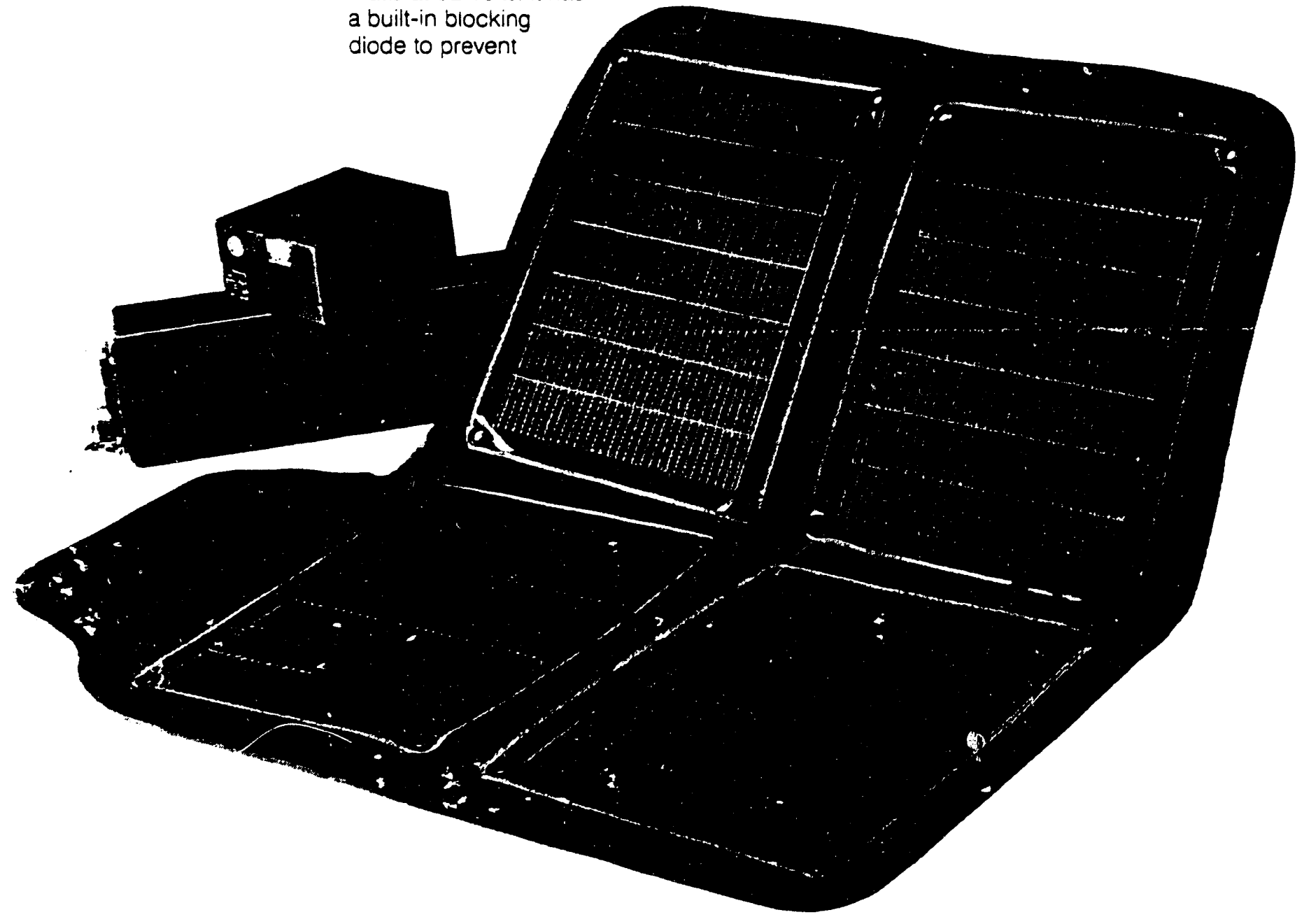




\section{Specifications}

Folded Panel

A. Length: 14 in. (35.6)

B. Width: 11 in. $(27.9 \mathrm{~cm})$

C. Depth: $0.75 \mathrm{in} .(1.9 \mathrm{~cm})$

Maximum voltage 32 volts at 10 watts.

Outer covering: Camo, Nylon

Cell Surtace: Dark blue with

nonreflective surface

Weignt: 2.5 pounds $(1.14 \mathrm{Kg})$

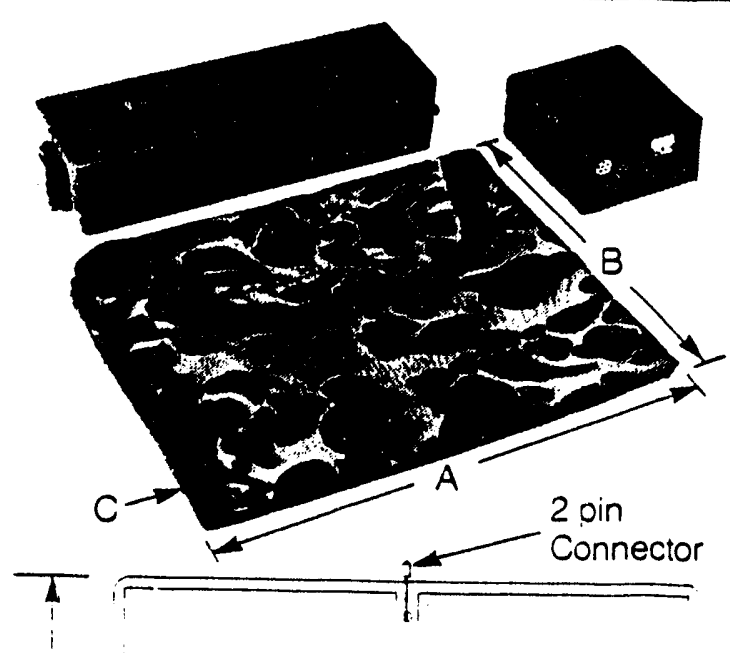

\section{Deployed Panel}

D. Length: 28 in. $(71.1 \mathrm{~cm})$

E. Width: 22 in. $(55.9 \mathrm{~cm})$

F. Depth: 0.19 in. $(0.48 \mathrm{~cm})$

\section{Deployment}

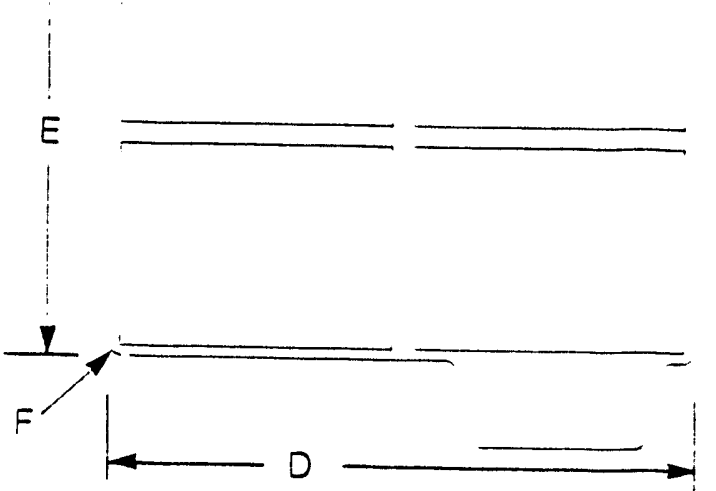

Unfold panel, place on an inclined slope towards sun and plug in connector to a battery or an appliance.

\section{Battery Charging Characteristics For Sovonics MP-3010*}

\section{Charging Current For 24 Volt Batteries Amp - Hr./Day}

\begin{tabular}{lccccc}
\hline Location & Spring & \multicolumn{1}{c}{ Summer } & & Autumn & Winter \\
\cline { 2 - 3 } Tennessee & 1.7 & 2.2 & & 1.3 & \\
Minnesota & 1.6 & 2.1 & & 0.9 & 0.9 \\
Massachusetts & 1.6 & 1.9 & 1.1 & 0.9 \\
Texas & 2.0 & 2.4 & 1.7 & 1.2 \\
Western Europe & 1.6 & 2.1 & 1.2 & 0.8 \\
North Africa & 2.4 & 2.6 & & 2.3 & 1.5
\end{tabular}

\section{Charging Output For Different Light Conditions For 24 Volt Batteries}

\section{Insolation}

Sunny $\left(100 \mathrm{~mW} / \mathrm{cm}^{2}\right)$

Partly Cloudy $\left(70 \mathrm{~mW} / \mathrm{cm}^{2}\right)$

Partly Sunny (25 $\left.\mathrm{mW} / \mathrm{cm}^{2}\right)$

Heavy Clouds $\left(10 \mathrm{~mW} / \mathrm{cm}^{2}\right)$

\section{Charging Current (mA)}

351

242

83

33
Max Power (Watts)

10.0

6.9

2.4

0.9

Module Titted In Direction of Sun

Represented By: 
TASK 2

POTENTIAL IMPROVEMENTS IN MANUFACTURING PROCESSES 


\section{OVERVIEW}

Over the last ten years ECD has been pioneering the development of cost-competitive large scale photovoltaic technology which utilizes amorphous silicon alloys based materials. Some of the significant contributions are listed below.

1. Proprietary continuous substrate roll-to-roll amorphous alloy-based solar cell production methods and machines. ${ }^{1-4}$

2. World's highest efficiency multiple-junction amorphous alloy solar cells with excellent stability. 5-6

3. The World's first and only commercialized photovoltaic technology which utilizes multiple-junction thin film solar cells. $7-10$

4. Largest size commercially available multi-junction single cell amorphous silicon alloy power module. $11-12$

ECD's technical approach for improving the performance and reducing the cost of PV modules will be to continue development of the two key manufacturing process technologies described below:

1. High efficiency, stable, low-cost, amorphous silicon alloys based thin film PV modules which utilize multiple band-gap, multiple-junction devices structure designed to respond to the broadest spectrum sunlight;

2. Automated roll-to-roll manufacturing process for high throughput, low-cost manufacturing.

ECD was the first company to recognize the value of a multiple-junction device to address the inherent efficiency limitation and performance degradation of amorphous silicon alloy single cell devices. It is now recognized that a stable module efficiency of 18-20\% may be achievable with an amorphous silicon alloy multiple band-gap, multiple-junction structure. ECD's proprietary manufacturing process is the only solar cell manufacturing process which uses an automated, continuous roll-to-roll manufacturing process. Utilizing this continuous roll-to-roll manufacturing process for producing multiple-junction 
solar cells together with advances to be achieved under Phase II of this program, we envision improved module performance and large volume manufacturing costs of less than $\$ 1.00$ per peak watt.

In the early stage of ECD's photovoltaic program, we recognized that roll-to-roll mass-production technology resembling newsprint production or aluminum foil manufacturing would be required to achieve the cost goals necessary for utility scale applications of photovoltaics. Based on this original concept, we have developed over the past ten years, a continuous roll-to-roll sequential plasma CVD deposition process utilizing thin stainless steel substrate. This manufacturing process has proven itself to be commercially viable and, more importantly, it can enjoy substantial economies of scale in larger capacity plants. These economies of scale result from the simple transport and vacuum control mechanisms employed, the ease of maintenance, and the ability of this process to use larger area substrates and faster substrate speeds. In contrast to glass substrate based batch manufacturing of amorphous silicon solar cells, for example, the rapid thermal equilibration of our metal substrate product allows rapid throughput of large area device in smaller production machines.

In the proposed Phase II program, ECD will develop advanced manufacturing technology to continue progress toward our long-term goal of producing modules with stable efficiency greater than $15 \%$ at a cost of less thain $\$ 1.00$ per peak watt. One of the key steps required to achieve these goals is transferring ECD's continuing $R$ \& D advances into manufacturing technologies. In order to improve the current manufacturing process, in Phase II we will undertake a focused manufacturing technology development program to transfer and further develop already proven $R \& D$ advances in the following areas:

1. Improving the roll-to-roll manufacturing processes by incorporating a multiple band-gap, multiple-junction device structure so as to produce solar cells and modules with higher stable efficiency.

2. Incorporating proprietary microwave plasma CVD manufacturing technology for high production throughput and higher gas utilization. 
Currently, ECD is constructing a $2 \mathrm{MW}$, turn-key plant to manufacture photovoltaic cells and modules which will utilize ECD's photovoltaic technology with triple-cell, spectrum-splitting structures. The production equipment is being built at ECD's facility in Troy, Michigan, and the equipment will be tested in Troy and then it will be shipped and installed in Moscow, U.S.S.R. ECD's joint venture in U.S.S.R., Sovlux, will operate the plant. In addition, we are in the process of designing and will build a multi-purpose roll-to-roll machine for manufacturing development which can produce the back-reflector, amorphous silicon alloy solar cell structure, and the transparent conducting layer in sequential deposition chambers. Major hardware used in this machine will be identical or similar to those used in our production machines. This machine will also have the capability to produce $p-i-n$ solar cell structures in a continuous roll-to-roll process in which the undoped amorphous silicon alloy layer is deposited using a proprietary high deposition rate microwave plasma CVD process.

We will use this machine to optimize the process parameters for a roll-to-roll manufacturing process to produce ainorphous silicon alloy solar cells with multiple band-gap, multiple-junction structure under Phase II of the proposed program.

In July, 1990, ECD and Canon Inc. of Japan formed a joint venture, United Solar Systems Corporation ("USSC")., for the manufacture of PV products in the United States. The U.S. Majority owned joint venture located in Troy, Michigan will initially utilize the roll-to-roll manufacturing plant developed and built by ECD. The Troy plant has been upgraded and expanded. The photovoltaic technologies which ECD has developed and will continue to develop will be directly available to the joint venture manufacturing in the United States.

II. REVIEW OF STATUS OF ECD'S TECHNOLOGIES WHICH ARE APPLICABLE FOR THE POTENTIAL IMPROVEMENTS IN MANUFACTURING PROCESSES

1. ECD's Multiple Band-Gap Multiple-Junction Technology for Stable High Efficiency Solar Cells 
ECD has been the leader in the use of multiple band gap, multiple-junction amorphous silicon alloy solar cell technology for many years. Table 1 summarizes the efficiency data reported by various laboratories for multiple-junction solar cells which utilize amorphous silicon-based materials.

In its research program, ECD has been working on the development of high quality, low band gap amorphous Si:Ge alloys, high quality doped layers, novel cell designs, and computer modeling of amorphous silicon alloy materials and devices and light-induced effects. These efforts have resulted in the development of the world's highest efficiency multiple-junction amorphous silicon alloy cell with excellent stability.

This monolithic device structure uses three cells stacked together with the semiconductor band gaps of the individual sub-cells tailored to capture different portions of the solar spectrum. It has now been clearly established that this device configuration gives higher efficiency as well as better stability for amorphous silicon alloy devices than single junction devices ${ }^{13}$. 
Table I. SUMMARY OF SOME RECENT RESULTS FOR AMORPHOUS SILICON BASED ALLOY MULTIPLE-JUNCTION SOLAR CELL PERFORMANCE ${ }^{13}$

Efficiency

$13.7 \%$

$13.0 \%$

$11.9 \%$

$11.3 \%$

$11.2 \%$

$10.8 \%$

$10.8 \%$

$10.5 \%$

$10.2 \%$

8. 3\%

$8.7 \%$

$7.4 \%$ $\underline{\text { Structure }}$

Triple

SS/Ag/ZnO/a-Si:Ge/a-Si/a-Si

Double

$\mathrm{SS} / \mathrm{Ag} / \mathrm{ZnO} / \mathrm{a}-\mathrm{Si}: \mathrm{Ge} / \mathrm{a}-\mathrm{Si}$

Double

SS/Ag/ZnO/a-Si/a-Si

Double

Glass/SnO $2 / \mathrm{a}-\mathrm{Si} / \mathrm{a}-\mathrm{Si}$

Double

Glass/SnO $2 / \mathrm{a}-\mathrm{Si} / \mathrm{a}-\mathrm{Si}$

Double

Glass/SnO $2 / \mathrm{a}-\mathrm{Si}: \mathrm{C} / \mathrm{a}-\mathrm{Si}$

Triple

SS/a-Si:Ge/a-Si/a-Si

Mitsubishi

Double

Glass/SnO 2 /a-Si:C/a-Si:Ge

Triple

Glass/TCO/a-Si/a-Si/a-Si:Ge

Triple

Glass/SnO $2 / a-S i: C / a-S i / a-S i: G e$

Double

Glass $/ \mathrm{SnO}_{2} / \mathrm{a}-\mathrm{Si} / \mathrm{a}-\mathrm{Si}: \mathrm{Ge}$

Triple

Glass/SnO $2 / a-S i / a-S i / a-S i: G e$
ECD

Fuji

Solarex

Sumi tomo

Chronar

Organization

ECD

ECD

Kanegafuchi

Fuji

Solarex

Chronar 
ECD has recently completed a 3 year $\$ 8.8$ million cost-sharing research contract administered by SERI, under which ECD developed high efficiency, multiple band-gap, multiple-junction amorphous silicon-based alloy thin film solar cells. Triple-cell devices have been fabricated in this research program with an active-area conversion efficiency of $13.7 \%$. This is the highest efficiency reported to date for any thin-film amorphous solar cell. A new three-year SERI research contract focused on development of stable, high-efficiency amorphous silicon multiple-junction modules has been recently awarded to ECD's subsidiary, United Solar Systems Corp. ("USSC"). The major goal of this program is to demonstrate by FY 1991 a stable, aperture area efficiency of at least $12 \%$ for two-terminal, different band-gap multiple-junction modules having an aperture area of at least $900 \mathrm{~cm}^{2}$. A comprehensive program on material development, single and multi-cell research and module optimization will be carried out to achieve this goal.

Our 13.7\% efficiency triple-cell amorphous silicon alloy solar cell utilizes a proprietary silicon-germanium alloy narrow band-gap material and wide band-gap micro-crystalline silicon doped layers. The triple cell device uses a stainless steel substrate coated with textured silver and zinc oxide for light trapping purposes. ${ }^{5-6}$ The device also utilizes a new, proprietary cell design which employs a graded band gap structure to enhance the performance of the bottom narrow band-gap silicon-germanium cell. The layer structure of the device is shown if Figure 14. This new design allowed us to reduce recombination and improve hole transport properties in the device ${ }^{14}$. Figure 15 and 16 show the $J-V$ characteristics and quantum efficiency of the device. 


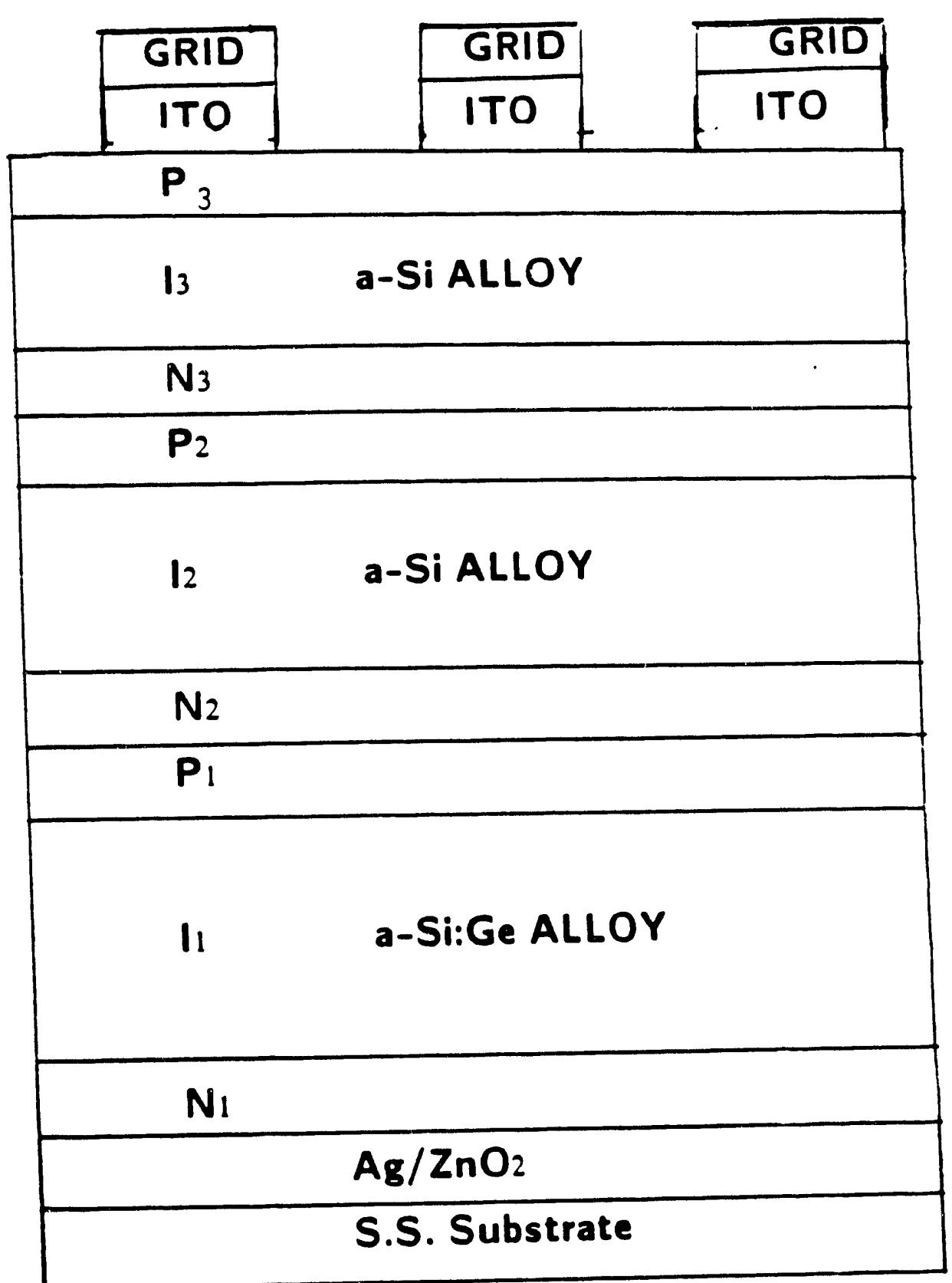

Fig. 14: Structure of the Three-Cell Triple Device 


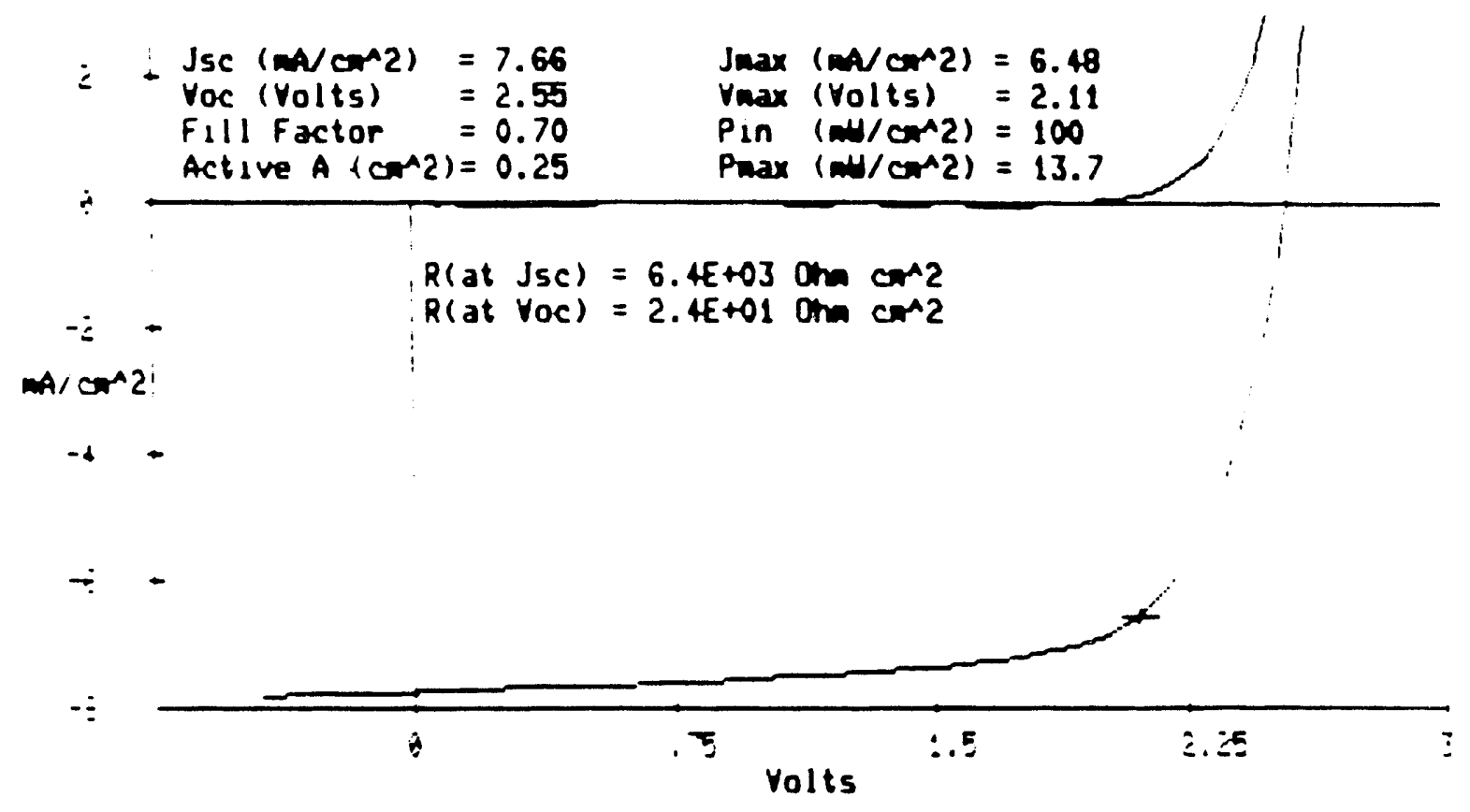

Fig. 15:

Characteristics of a Three-Cell

Triple Device Measured under Global

AMI.5 illumination at $25^{\circ} \mathrm{C}$ using

a Triple-Source Simulator. 


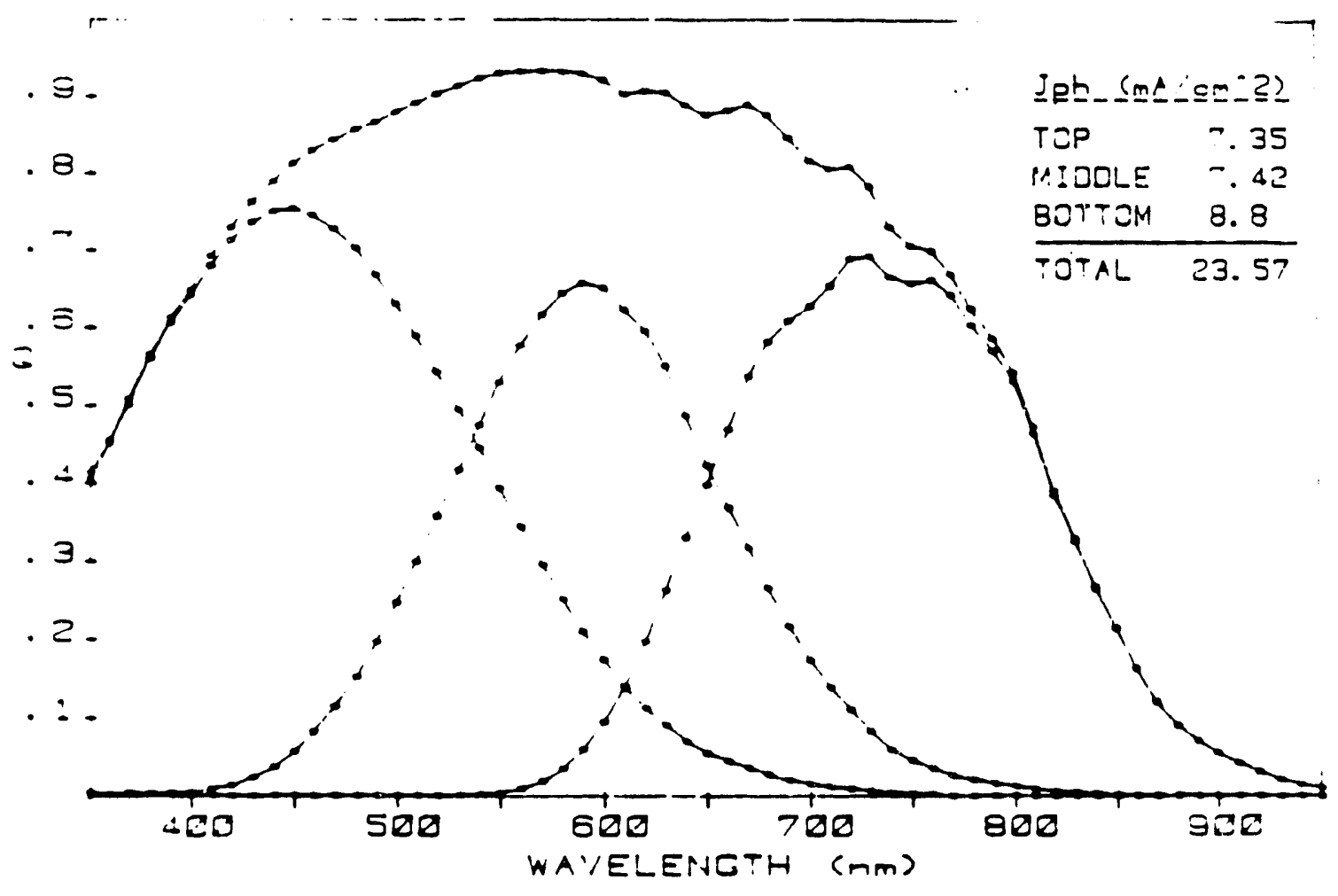

Fig. 16: Quantum Efficiency of the Triple Device in Fig. 15. 
2. ECD's Microwave Plasma Assisted CVD Technology for High Rate Deposition of Amorphous Silicon

The roll-to-roll RF plasma assisted CVD processor is the most technically sophisticated and also the most costly piece of equipment in our current manufacturing plant. The throughput of the RF plasma assisted CVD processor is the determining factor for the production throughput of the entire plant, and the throughput of this rate-determining process is proportional to the rate of RF plasma assisted CVD deposition of amorphous silicon alloys. Generally, a $2-5 \AA / s e c$ deposition rate is used in research scale processing, while a $5-20 \AA / \mathrm{sec}$ deposition rate is used in production. The maximum deposition rate ever achieved for RF plasma assisted CVD of low electronic defect density amorphous silicon alloy materials is 15 $20 \AA / \mathrm{sec}$. Attempts to increase the deposition rate over $20 \AA / \mathrm{sec}$ (by increasing RF power), invariably results in gas phase nucleation which gives rise to the formation of powder in deposition chamber and degradation of material quality.

ECD's approach to solve this problem is to utilize a microwave plasma assisted CVD process which has the capability of generating a highly activated plasma at low pressure which can avoid the formation of powder and other undesirable gas phase species while maintaining the high concentration of active species necessary for a high deposition rate process. Specifically, ECD has developed a proprietary low pressure microwave assisted CVD process to deposit high quality amorphous silicon alloy material at high deposition rate (over 100R/second). 15 This process has been applied to the deposition of amorphous silicon alloy electro-photographic photoreceptors. ${ }^{16-17} \mathrm{~A}$ photoreceptor manufacturing machine employing this proprietary technology has been designed and constructed by ECD and is now in commercial operation in Japan (see figure 17). 


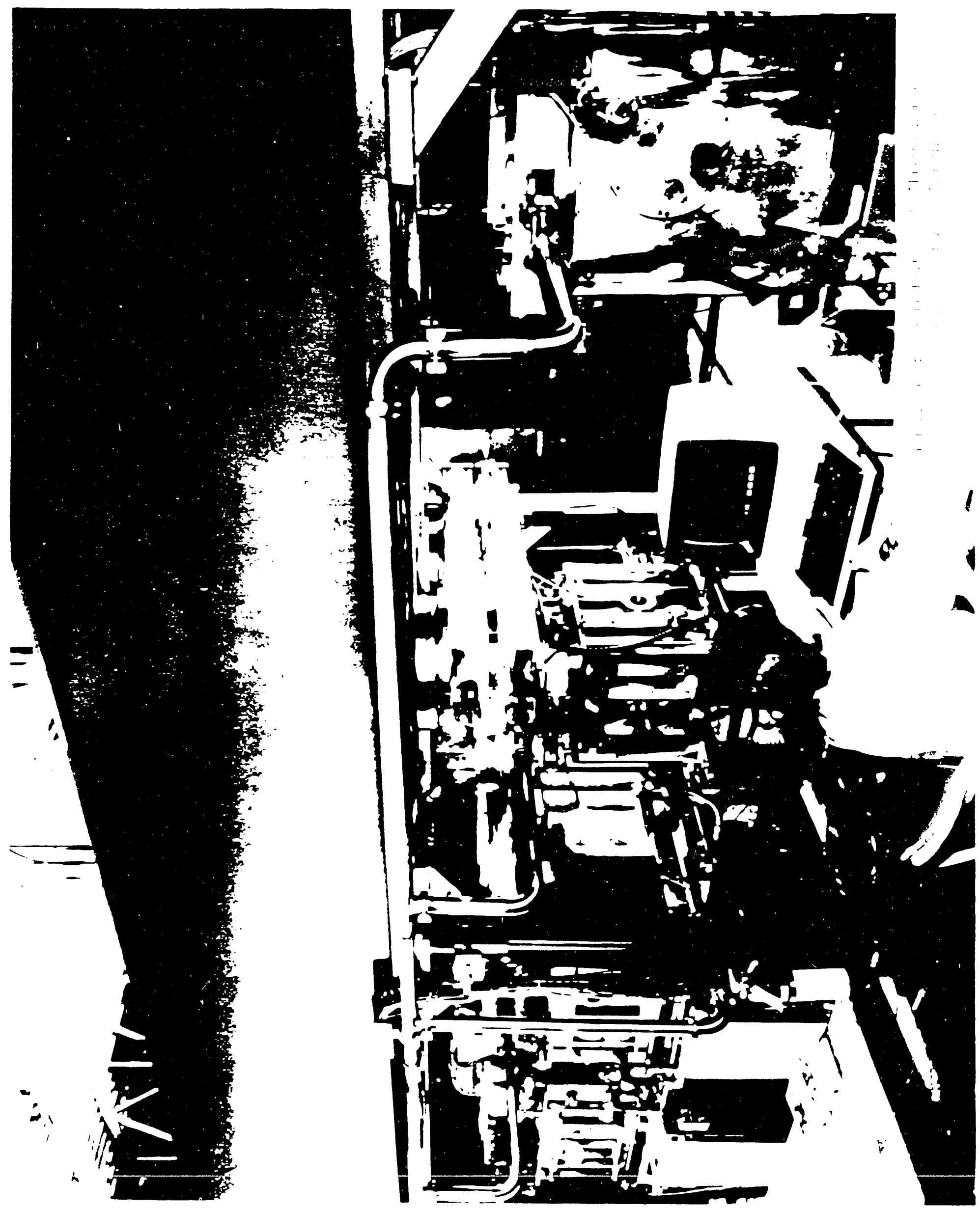


ECD has also demonstrated the capability to scale up its proprietary low pressure microwave plasma CVD process for use in roll-to-roll deposition systems through the development of a proprietary linear microwave applicator. This technology, which will be described later, can achieve very high deposition thickness uniformity (better than $2 \%$ across a $12^{\prime \prime}$ substrate in moving substrate systems).

An additional advantage of using the ECD low pressure microwave plasma CVD process is its enhanced gas utilization efficiency. Because of the very high electron density in the low pressure microwave excited plasma, essentially $100 \%$ of the silicon containing feedstock gas is decomposed into depositing species. This reduces manufacturing cost both by allowing the most efficient use of the feedstock gas and by reducing costs associated with removal and disposal of unreacted feedstock gas from the process pump effluent.

ECD has also shown that the quality of amorphous silicon materials deposited by the microwave process can be further improved by utilizing an indirect excitation method. In this approach, a carrier gas such as $\mathrm{He}$ is initially excited by the microwave plasina and used to transfer energy to the silicon containing gas such as silane which results in its decomposition and subsequent deposition as amorphous silicon. There have been reports by ECD and other researchers which describe high electronic quality amorphous silicon alloy films deposited by indirect excitation. 18 All of the processes reported by other workers, however, have exhibited small deposition rates. This has occirred because either the excitation of the transfer gas species or the rate of energy transfer to the depositing gas species has not been efficient. ECD has developed proprietary means to solve both of these problems and has demonstrated in a laboratory scale apparatus the deposition of amorphous silicon alloy material at rates exceeding $500 \mathrm{~A} / \mathrm{sec}$. 


\section{LONG RANGE POTENTIAL BENEFITS OF THE IMPROVED PROCESSES}

The long range potential benefits of incorporating multiple-junction, high efficiency solar cell designs and high deposition rate with microwave plasma CVD technology in our advanced manufacturing processes which utilize continuous roll-to-roll process are enormous. Barriers to the widespread use of photovoltaic generated electricity have always been economic, and the key economic figure of merit is installed cost per peak watt of power output. Advances in manufacturing technology which result in higher efficiency devices affect this figure of merit directly by reducing the cost per output watt of the solar module itself and, indirectly, by reducing the cost of real estate and module support structure required to produce the photovoltaic power. Advances in manufacturing technology which increase the production rate of solar cells directly reduce unit cost since a major portion of the manufacturing cost is the capital cost of the manufacturing plant.

Through the incorporation of multiple band-gap, multiple-junction amorphous silicon alloy solar cell structures and through increases in feedstock gas utilization and production throughput, ECD will make important strides in achieving its near term goal of $10 \%$ stable commercial module efficiency and manufacturing costs of less than $\$ 1.00$ per peak watt in high volume production. Incorporation of a high rate deposition process utilizing our microwave plasma cvo process will lead to further reduction in manufacturing cost.

Theoretical calculations show that conversion efficiency in excess of $20 \%$ can be achieved using all amorphous thin films with multiple band-gap, multiple junction structures. Our long term goal is to achieve stable module efficiency over $15 \%$ in our continuous cost-effective roll-to-roll process utilizing multiple band-gap, multiple-junction photovoltaic technology. 
TASK 3

PROBLEMS THAT MAY IMPEDE THE ACHIEVEMENT

OF THE POTENTIAL BENEFITS DESCRIBED IN TASK 2 
I. ANTICIPATED PROBLEMS FOR TRANSFERRING MULTIPLE BAND-GAP, TRIPLE-CELL TECHNOLOGY TO ROLL-TO-ROLL MANUFACTURING PROCESSES

13.7\% energy conversion efficiency amorphous silicon based solar cells with a multiple band-gap, triple-cell structure have been demonstrated using a small area device produced in a laboratory scale batch process. In order to transfer this technology to ECD's manufacturing process, the following elements have to be accomplished in the continuous roll-to-roll manufacturing process.

1. Efficient back-reflector for light trapping.

2. High quality doped layers.

3. High quality intrinsic layers.

4. Suitable device design.

5. Matching of component cells.

Other issues which we will address are:

1. Production efficiency including uniformity and yield.

2. Cost-effectiveness.

\section{Optical Enhancement}

Calculations have demonstrated that the degree of optical enhancement which can be accomplished through the use of "scattering back reflectors" is determined by the refractive index of the solar cell material. For amorphous silicon alloy, multiple internal reflections can result in up to 25 passes of the light rays within the cell, effectively increasing the useful absorbing distance in the cell by a factor of 25 . It is therefore, important to produce a suitable, textured back reflector layer to achieve high efficiency in these devices.

In our earlier manufacturing process, a textured Al based alloy deposited film was used as a back-reflector. As has been described previously, the $13.7 \%$ efficiency device use a textured $\mathrm{Ag} / \mathrm{ZnO}$ back-reflector system which has substantially higher reflectivity than a single Al based alloy film. To employ this system in a 
commercial product, a roll-to-roll process for producing textured $\mathrm{Ag} / \mathrm{Zno}$ back-reflector or its equivalent will have to be developed and qualified for its consistency, reproducibility, uniformity, and production yield. Because of the non-planar morphology of this back reflector system, special attention will have to be focused on achieving the benefits of total internal reflection optical enhancement without suffering a reduction in yield due to shunting of the devices.

\section{High Quality Doped Layers}

The requirements for $n$ and $p$ doped layers is more stringent in multiple-junction cells than in single-cell structures. One needs very high conductivity doped layers so that there is no rectifying internal junction between adjacent $n$ and $p$ layers. The use of high conductivity, low activation energy $n$ and $p$ layers also increases the built-in electric field, thereby increasing the open-circuit voltage and the fill factor. It is also essential that the $n$ and $p$ layers contribute very small optical losses to the system. This condition is also more stringent in the case of triple-cells, since light has to go through several layers of $n$ and $p$ material.

ECD has developed technology for depositing proprietary micro-crystalline $n$ and $p$ layers for high-efficiency multiple-junction devices. Because of their micro-crystalline nature, these layers have both high conductivity and low optical absorption so that optical as well as electrical losses in doped layers are minimum. Transferring this technology to the roll-to-roll manufacturing process has been already accomplished for the most part in our current production processes. Production parameters including yield, consistency, uniformity etc. have already been qualified. Further advancement of this technology, especially in the topmost $p$ layer of the spectrum splitting cell, will lead to further increases in the open circuit voltage of solar cells. 


\section{High Quality Undoped Layers}

As has been described previously, ECD's high efficiency, multiple band-gap, multiple-junction cells utilize two amorphous silicon, undoped layers in the top two cells and an amorphous silicon-germanium undoped layer for the bottom cell. Producing high quality amorphous silicon intrinsic layers with an effective or optical band-gap of $1.7 \mathrm{EV}$ already has been demonstrated in our current manufacturing process. However, a solar cell device quality amorphous silicon-germanium intrinsic layer with an effective band-gap of $1.4 \mathrm{EV}$ has never been produced under mass production manufacturing conditions. Optimizing deposition parameters and hardware design for the roll-to-roll plasma enhanced CVD process to produce high quality amorphous silicon-germanium alloy will be a key issue in the proposed program.

Small area multiple band-gap multiple-junction research devices have been optimized previously at a relatively low deposition rate about $2 \AA / \mathrm{sec}$. Process research to achieve a higher deposition rate in a production machine is required to transfer this technology to a manufacturing scale. A higher deposition rate will have to be achieved, of course, without compromising the quality of materials. Also, in order to produce uniform and consistent solar cells with a multiple-gap triple cell structure on $1,200 \mathrm{ft}$. to $2,500 \mathrm{ft}$. long 14 inch wide stainless steel substrate, substantial manufacturing process engineering will have to be undertaken. Maintenance of steady state deposition conditions in the plasma chambers over a long period of time is required to achieve longitudinal uniformity, and hardware design and deposition parameters such as gas flow profiles will be optimized to achieve transverse uniformity.

Achieving high gas utilization efficiency for the more costly germane which is used in the multiple band-gap cell is an important factor in reducing the manufacturing cost. Hardware and deposition parameters will be optimized to achieve simultaneously a high gas utilization and high electronic quality deposited semiconductor films. 


\section{Device Design}

The density of mid-band-gap electronic defect states in silicongermanium alloy is generally higher than arnorphous silicon alloys which don't contain germanium. This is important because mid-band-gap states give rise to electron-hole recombination in the bulk material which plays a crucial role in lowering the performance of amorphous silicon alloy solar cells. ECD has developed a novel band-gap profiling scheme for the material which constitutes the intrinsic layer in a $p-i-n$ device so as to assist hole transport by creating an internal electric field within the material.13-14 Laboratory results confirm the theoretical predictions that solar cell performance is improved by optimizing the compositional profile for silicon-germanium alloy to achieve the desired graded band-gap.

In order to produce a graded band-gap in the silicon-germanium layer in a continuous roll-to-roll process, the RF plasma deposition of silicon and germanium containing gas mixture has to be delivered in such a way as to produce a gas composition spatial profile in the deposition chamber along the longitudinal direction. Parameters which will affect the spatial compositional profile are: a.; the gas mixture composition; b) basic gas flow pattern; c) the temperature distribution pattern; d) the deposition power distribution; and e) deposition chamber hardware configuration including inlets ports for gases, the position and shape of pumping ports and the distance from the substrate to the RF cathodes. Computer simulations as well as deposition experiments will be performed to determine optimum manufacturing process parameters.

\section{Device Current Matching}

In a tandem or a triple-cell device structure, the short-circuit current is controlled by the lowest current delivered by any constituent sub-cell. It is therefore necessary to match the output of individual sub-cells to obtain optimum performance. Important 
advances in device modeling and diagnosis have been previously accomplished at ECD and reported in the literature. ${ }^{5-6,13-14}$ one of the manufacturing engineering challenges is to achieve device matching under production conditions. Development of an accurate and reliable in-line thickness monitoring system to ensure device sub-cell current matching is an essential task in this program.

II. ANTICIPATED PROBLEMS IN DEVELOPING MICROWAVE PLASMA ASSISTED CVD HIGH DEPOSITION RATE MASS PRODUCTION TECHNOLOGY

ECD has pioneered a proprietary microwave enhanced CVD plasma deposition process for depositing high quality amorphous silicon at a high rate $(100 \AA / \mathrm{sec})$. This process has been scaled-up and is now employed in the commercial production of photocopier drums. The microwave process has also been used to deposit amorphous silicon solar cell materials. In a small-scale research machine for instance, relatively high quality intrinsic materials have been prepared, however. high efficiency solar cells have never been demonstrated with materials produced at high deposition rate using the microwave process.

\section{OTHER AREAS WHERE PROCESS IMPROVEMENTS CAN CONTRIBUTE TO MANUFACTURING COST REDUCTION}

1. Improvements in module efficiency by narrowing scribe lines, grid lines, and bus-bar lines.

2. Automation of module assembly process.

The current low volume module assembly is labor intensive. In a high volume manufacturing facility, automation would not only reduce cost by increasing speec of assembly, but it would result in more efficient use of solar cell material by allowing the use of tighter mechanical tolerances. Significant losses now occur due to large safety margins built into the design required for manual assembly.

Narrowing the grid and buss lines used for current collection would significantly minimize the shadowing losses. The present buss designs are quite wide to allow manual assembly. Experience has shown that any 
reduction in their size would significantly increase the difficulty of handling the bus bar tape in the manual process. However, automated assembly can allow reduction of the size of bus lines. Alternative current collection schemes will also be investigated. Similarly, grid lines also account for a major shadow loss simply due to the large number of them. Alternate means of deposition of grid lines will be investigated. One approach may be to electroplate grid contacts instead of screen printing them. Electroplated grid lines can be significantly narrower, reducing the shadowing loss. Scribe lines are areas where TCO is removed to allow individual cells and strips to be defined. Only along these lines it is possible to use a shear to cut apart individual strips, and this means that the lines must be sufficiently wide to provide for quick manual operation. Automated module assembly with computer controlled alignment will allow tighter mechanical tolerances and significantly reduce these losses as well. In addition to the loss reduction described above, automation will also allow faster operation and minimize errors due to handling. 
TASK 4

TECHNICAL APPROACH AND TIME/COST ESTIMATE 


\section{OVERVIEW}

ECD will use a continuous roll-to-roll deposition machine to carry out the manufacturing process development program to transfer our multiple band-gap, multiple-junction technology from a laboratory scale to a continuous roll-to-roll production scale. We will also use the same manufacturing technology development machine to advance ECD's microwave plasma deposition technology.

Major efforts in the manufacturing process development program will be directed towards solving the problems identified and described in TASK 3 of this report. As described previously, the multiple band-gap, multiple-junction solar cell consists of stainless steel substrate, back reflector, multiple band-gap layers of amorphous silicon based alloys, and the transparent conducting oxide layer. These various component layers will be produced in a continuous roll-to-roll process in the manufacturing technology development machine and fully characterized. Characterized and optimized complete solar cell structures will also be produced in the machine. These solar cells will also be fabricated into modules. The performance of the modules, specifically their efficiency and stability, will be tested and evaluated as a function of manufacturing process conditions.

The overall object of the program is to optimize the deposition parameters and hardware design of our continuous roll-to-roll process to achieve the following objectives:

1. To improve the module performance:

- Efficiency

- Stability

2. To improve the manufacturing efficiency:

- Yield

- Uniformity

- Consistency 
3. To reduce the manufacturing cost:

- High utilization of materials

- Use of low cost materials

- High production throughput

- Automation

II. PROCEDURES AND EQUIPMENT

ECD will use a multi-purpose, roll-to-roll machine to carry out the manufacturing development program outlined in this section. A schematic drawing of this machine is shown in Figure 18.

The multi-purpose roll-to-roll machine has several vacuum compartments as listed below;

1. Pay-off chamber

2. P-deposition chamber

3. Gas gate

4. I-deposition chamber

5. Multi-purpose deposition chamber for:

a. Back-reflector

b. Transparent conducting oxide

c. Microwave deposition of amorphous silicon alloys

6. Gas gate

7. N-deposition chamber

8. Take-up chamber 


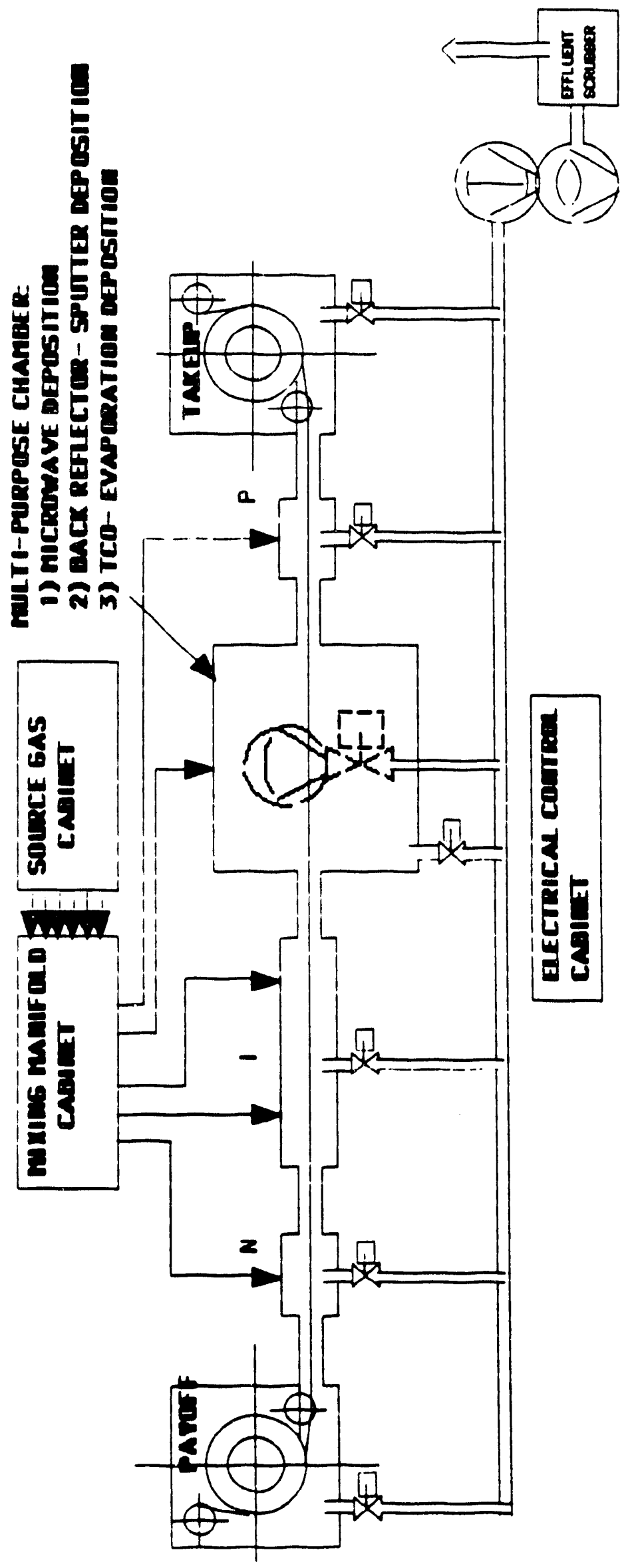

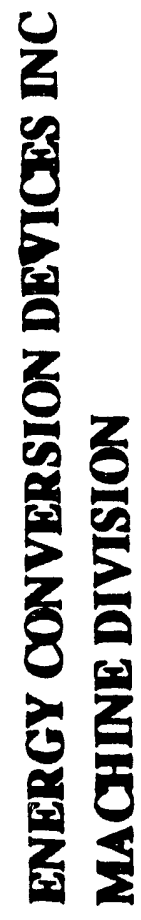

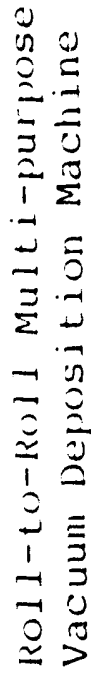

$\ddot{0}$

旨 
The pumping system consists of: a diffusion pump, Roots Blower, and mechanical pump. Vacuum, hardware and the control systems used in this multi-purpose machine are identical or very similar to those used in our current manufacturing machine. The multi-purpose machine will process a roll of stainless steel substrate 1,000 feet long 14 inches wide over a speed range of 1 inch to 2 feet per minute.

We will use this machine to produce the following depositions in a continuous roll-to-roll process:

- Back-reflector deposition: DC magnetron deposition of $\mathrm{Ag} / \mathrm{Zno}$ layer or alternative layer.

- P-doped micro-crystalline silicon.

- Intrinsic amorphous silicon alloy

- Intrinsic amorphous silicon-germanium alloy with compositional profile.

- N-doped micro-crystalline silicon.

- Transparent conducting oxide.

- Intrinsic amorphous silicon deposited at high rate using microwave plasma CVD.

- Intrinsic amorphous silicon - germanium alloy deposited at high rate using microwave plasma CVD.

This machine will be used to produce in a single pass continuous roll-to-roll process, a $p-i-n$ solar cell structure. It can also produce a $p-i-n / p-i-n / p-i-n$ triple-cell solar cell structure using sequential processing. In addition, $p-i-n$ solar cells with the intrinsic layer deposited using the microwave plasma CVD process will be produced in a single pass.

Small-scale process equipment similar to the equipment which is used in our current manufacturing plant for $Q A / Q C$ (described in TASK 1) will be used to fabricate small area solar cells on stainless steel. The current, voltage, and fill factor under AM1.5 for these cells will be measured. Q-curve measurements will be used to evaluate the spectral response. Biased-Q measurements which utilizes a special triple light 
source will be performed to obtain information about individual sub cells of the multiple-junction structure. Degradation characteristics of solar cells will be measured. In addition, yield data will be obtained.

By utilizing a small scale module assembly set-up, photovoltaic modules will be fabricated from multiple band-gap, multiple-junction solar cells produced in the manufacturing technology development machine. Efficiency and stability of finished modules will be evaluated.

A variety of measurements to characterize optical, electrical, physical, chemical, and structural properties of individual component layer will be carried out. Engineering analysis including computer simulations to improve the function and performance of the machine will be performed.

\section{TECHNICAL APPROACH}

1. Improving the Roll-To-Rol! Manufacturing Technology by Incorporating Multiple-Band-Gap Multiple-Junction Structure.

We have identified in TASK 3 several specific areas which require major efforts. They are summarized below:

To produce in a continuous roll-to-roll process a textured $\mathrm{Ag} / \mathrm{ZnO}$ back-reflector or the equivalent which will be qualified for its consistency, reproducibility, uniformity, production, yield, and cost-effectiveness.

- To produce in a continuous roll-to-roll process high quality amorphous silicon-germanium intrinsic layer with the optical band-gap of approximately $1.4 \mathrm{eV}$ at a high deposition rate.

- To produce in a continuous roll-to-roll process a deposited amorphous silicon-germanium layer with optimum compositional profile to achieve the highest performance.

To achieve a high germane utilization in a continuous roll-to-roll process. 
We will evaluate the effect of the physical properties and thickness of the Zno layer on the performance of the textured $\mathrm{Ag} / \mathrm{ZnO}$ back-reflector. There have been some research results which suggest that these characteristics have a strong and, as yet not fully understood, effect on the performance of solar cells - particularly efficiency and yield.

Deposition parameters including gas-mixture composition, pressure, substrate temperature, and RF power will be optimized in the manufacturing technology development machine to achieve the deposition of high quality amorphous silicon-germanium material uniformly and consistently over a large-area at high deposition rate. Hardware designs for machine parts will also be optimized. Effect of DC bias on substrate relative to the plasma will also be investigated.

Fundamental physical characteristics of the plasma CVD film will be investigated during optimization. These include dark conductivity, photoconductivit:; optical absorption both above and below the band-gap, and mobility-lifetime product using time-of-flight measurements. Film compositional homogeneity will be determined by electron microprobe and Auger analysis.

In order to achieve the highest conversion efficiency for silicon-germanium solar cells, research performed earlier at ECD has shown that the compositional profile of the undoped silicon-germanium layer will play a key role. We will use a specially designed gas-inlet manifold system to produce varying gas-mixtures which can be distributed and injected at specific locations on the cathode plate. A large number of compositional profiles can be obtained with this gas distribution manifold relatively easily. Computer modeling of plasma gas reaction kinetics will be performed for the optimization as described previously.

The objective of this program is:

1. to improve the module performance;

2. to improve the manufacturing efficiency;

3. to reduce the manufacturing cost. 
Therefore, the optimization will be aimed at achieving not only tigh efficiency and stability but also other objectives including high manufacturing efficiency and low cost.

Development of wider band-gap materials and alternative narrow band-gap materials will also be explored as other means to improve solar cell energy conversion efficiency.

In order to achieve high utilization for germane gas, we will test a cathode design in which germane gas flows longitudinally. In this way, germane can be depleted effectively in the deposition chamber to inprove, germane utilization. The relative rate of depletion of germanium and silicon containing gases (silane, disilane and silicon tetrafluoride) will determine the compositional profile (germanium vs. silicon) in the device. Therefore, the compositional profile can be controlled by changing deposition parameters including the gas mixture in such a cathode hardware design. Deposition parameters including gas mixture and flow patterns will be optimized to maximize germanium gas utilization while keeping the high device performance.

\section{Incorporating Microwave Manufacturing Technology}

We will utilize our proprietary linear applicator microwave plasina source designed for a continuous process.

A schematic diagram of microwave CVD deposition system is shown in Figure 19.

The microwave CVD system consists of:

1. Microwave Generator

2. Microwave Waveguide

3. Linear Applicator

4. Reaction Gas Feeding System

5. Vacuum Pumping System 


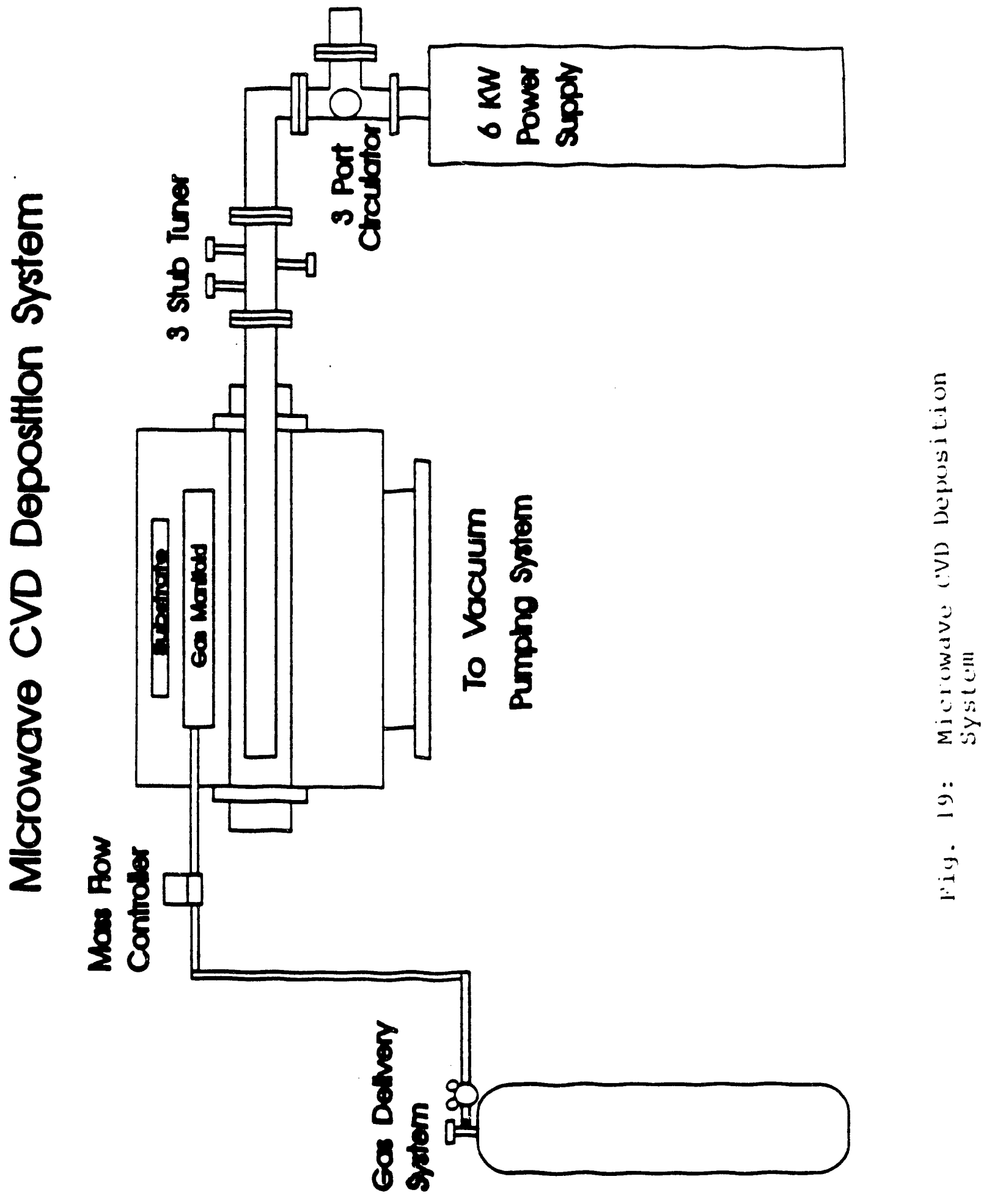


A $6 \mathrm{~kW} 2.45 \mathrm{GHZ}$ microwave generator (Model S6F from Cober Manufacturing Co.) will be used as a power source. Microwaves are directed from the generator through suitable isolation and power measurement devices into the ECD patented Linear Applicator located within the cylindrical quartz microwave window within the vacuum chamber. The Linear Applicator is designed to apply a uniform thin film coating onto a moving substrate as illustrated in Figure 20 .

The Linear Asplicator is designed to generate a uniform plasma over a 12-inch linear distance for high rate microwave plasma CVD deposition. The Linear Applicator is constructed so that microwave energy radiates uniformly out from the enclosed waveguide. The "Radiating Waveguide" consists of a section of waveguide into which a large slot has been cut, and an adjustable aperture, consisting of a flat piece of metal which partially covers the large slot. Adjusting screws permit the size and shape of the open portions of the aperture to be changed. A uniform plasma can therefore be achieved with the Linear Applicator by adjusting the spatial distribution of the microwave radiation field through appropriate manipulation of the position of the plate over the large slot.

The Linear Applicator structure the "Radiating Waveguide" is inserted into a cylindrical quartz tube, which becomes, in effect, the microwave window through which energy is supplied to the plasma. Note that while the volume of the deposition chamber is evacuated to a low operating pressure, the inside of the quartz tube which contains the radiating waveguide remains at atmospheric pressure.

A maximum one-atmosphere pressure differential therefore exists across the walls of the quartz tube, directed from the inside out. Because the cross-section of the quartz tube is circular, however, the mechanical stresses associated with the pressure differential are distributed evenly and are tangential everywhere, resulting in a uniform tensional stress in the quartz with no shear component. This allows the wall of the quartz tube enclosure to be made very thin. Circulation of cooling air through the atmospheric pressure interior of the thin wall quartz enclosure facilitates rapid heat removal from the plasma region. 
This ability for rapid heat removal allows the use of very large area, high power microwave plasma regions without problems associated with window overheating.

We will continue evolution of the design of the Linear Applicator to incorporate a capability for indirect excitation of silicon and germanium containing gases. In this mode of operation, the microwave plasma will excite a carrier gas such as He, which will, in turn, excite silicon and germanium containing gas by collisional energy transfer. It has been shown by us and other researchers that CVD deposition of silicon and germanium containing gas can be controlled more effectively by this indirect excitation, so as to deposit higher quality materials having lower density of electronic defect states. We will use this technique to optimize the quality of intrinsic layer deposited by microwave.

Another, different approach for producing narrow band-gap solar cell materials at ECD has been invented and is currently the subject of ongoing research at ECD. This new proprietary microwave plasma deposited material technology will also be investigated on the multi-purpose machine during the Phase II development program.

We will use the multiple-purpose roll-to-roll machine to optimize the microwave plasma process for producing $p-i-n$ solar cells. $p$ and $n$ layers will be deposited by the RF plasma process and the $i$ layer will be deposited by high deposition rate microwave processes.

Computer modeling and a preliminary design of these special, large pressure gradient gas isolation gates have already been accomplished at ECD within the current Sovlux machine development program. We will utilize this gas gate technology in the construction of the multi-purpose machine for the Phase II development program. In the future, further development of this technology should make it possible to design a totally integrated roll-to-roll processor which can deposit an entire solar cell structure including back-reflector, amorphous silicon alloy layers and TCO in a single pass. This type of fully integrated processing machine will allow substantial additional increases in production throughput. 


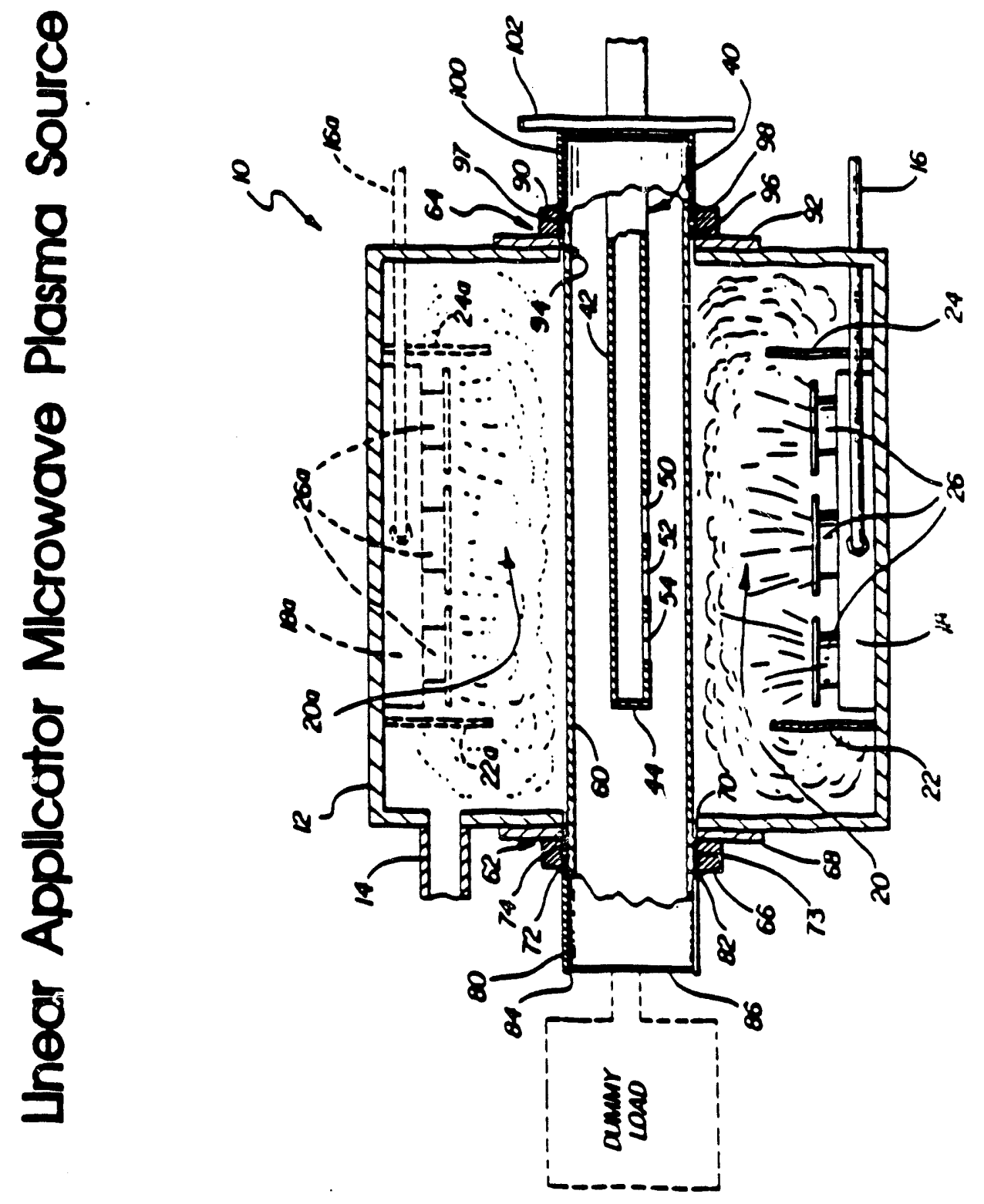

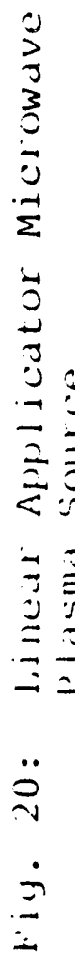




\section{Figures}

1. Photovoltaic Manufacturing Plant 4

2. Substrate Washing Machine 7

3. A photograph of Substrate Washing Machine used in 8 the Production of Tandem a-Si Solar Cells

4. Back Reflector Machine

5. A Photograph of Back Reflector Machine 12

6. Roll-To-Roll Amorphous Silicon Alloy Processor 16

7. Proprietary Manufacturing Process 17

8. A photograph of Tandem-Junction Amorphous Silicon 18 Alloy Deposition Processor

9. Ovonic TCO Machine 21

10. A photograph of TCO Deposition Machine 22

11. Power Plus TM 28

12. P25 Module Specification 29

13. A photograph of 20KW Maui Installation 30

14. Structure of the Three-Cell Triple Device 50

15. Characteristics of a Three-Ce11 Triple Device Measured 51 under Global AMI.5 illumination at $25^{\circ} \mathrm{C}$ using a Triple-Source Simulator

16. Quantum Efficiency of the Triple Device in Figure 15

17. Picture of Microwave Deposition Machine 54

18. Roll-To-Roll Multi-Purpose Vacuum Deposition Machine 67

19. Microwave CVD Deposition System 72

20. Linear Applicator Microwave Plasma Source 86 


\section{REFERENCES}

1. Production of Tandem Amorphous Silicon Alloy Cells in a Continuous Roll-To-Roll Process, M. Izu and S. R. Ovshinsky, SPIE Proc. 407, 42 (1983).

2. Roll-To-Roll Plasma Deposition Machine for the Production of Tandem Amorphous Silicon Alloy Solar Cells, M. Izu and S. R. Ovshinsky. Thin Solid Films 11955 (1984).

3. Amorphous Silicon Solar Cells Production in a Roll-To-Roll Plasma CVD Process, H. Morimoto and M. Izu, JARECT 16 (1984); Amorphous Semiconductor Technology \& Devices, North Holland Publishing Company, Edited by $Y$. Hamakawa, 212 (1984).

4. Roll-To-Roll Mass Production Process for Amorphous Silicon Solar Cell Fabrication, S. R. Ovshinsky, Proc. International PVSEC-1, 577 (1988).

5. High efficiency Multiple-Junction Solar Cells using Amorphous Silicon and Amorphous Silicon-Gemanium Alloys, J. Yang, R. Ross, T. Glatfelter, R. Mohr, G. Hammond, C. Bernotaitis, E. Chen, J. Burdick, M. Hopson and S. Guha, Proc. 20th IEEE P.V. Spec. Conf. 241 (1988).

6. Physics of High Efficiency Multiple-Junction Solar Cells, J. Yang, R. Ross. R. Mohr, and J.P. Fournier, Proc. MRS Symp. Vol.95, 517 (1987).

7. Performance of Large Area Amorphous Silicon Based Single and Multiple-Junction Solar Cells, P. Nath and M. Izu, Proc. of the 18th IEEE Photovoltaic Specialists Conf., Las Vegas, Nevada, 939 (1985).

8. IMW Amorphous Silicon Thin-Film PV Manufacturing Plant, P. Nath, $K$. Hoffman, J. Call, C. Vogeli, M. Izu and S. R. Ovshiniky, Proc. of the 3rd International Photovoltaic Science and Engineering Conf., Tokyo, Japan, 395 (1987).

9. Conversion Process for Passivation Current Shunting Paths in Amorphous Silicon Alloy Solar Cells, P. Nath, K. Hoffman, C. Vogeli and S. R. Ovshinsky, Appl. Phys. Lett. 53 (11), 986 (1988).

10. Yield and Performance of Amorphous Silicon Based Solar Cells Using Roll-To-Roll Deposition, P. Nath, K. Hoffman, J. Call, G. DiDio, C. Vogeli and S. R. Ovshinsky, Proc. 20th IEEE P.V. Spec. Conf., 293 (1988).

11. A New Inexpensive Thin Film Power Module, P. Nath, K. Hoffman, $C$. Vogeli, K. Whelan and S. R. Ovshinsky, Proc. 20th IEEE P.V. Spec. Conf., 1315 (1988).

12. Fabrication and Performance of Amorphous Silicon Based Tandem Thotovoltaic Devices and Modules, P. Nath, K. Hoffman, and S. R. Ovshinsky, 4th International P.V. Science and Encineering Conf., Sydney, Australia, (1989). 
13. Advances in High-Efficiency, Multiple-Band-Gap, Multiple-Junction Amorphous Silicon Based Alloy Thin-Film Solar Cells, S. Guha, A Paper Presented at MRS Spring Meeting, San Diego, April (1989).

14. Amorphous Silicon-Germanium Alloy Solar Cells with Profiled Band-Gaps, J. Yang, R. Ross, T. Glatfelter, R. Mohr, and S, Guha, MRS Symposium Proc. Vol. 149, 435 (1989).

15. Low Pressure Microwave PECVD Technology, M. Izu, S. J. Hudgens, J. Doehler and B. Dotter, Proc. 4th International Conf. on Vacuum Web Coating, 129 (1990).

16. High Deposition Rate Amorphous Silicon Alloy Xerographic Photoreceptor, S. J. Hudgens añd A. J. Johncock, Proc. MRS Syinp. Vol. 49, $403(1985)$.

17. Amorphous Semiconductors for Microelectronics, S. J. Hudgens, Proc. SPIE Vol. 617, 95 (1986).

18. Intrinsic Micro-crystalline Silicon Deposited by Remote PECVD: A New Thin Film Photovoltaic Material, C. Wang and G. Lucovsky, Proc. 21 st IEEE P.V. Spec. Conf. 1614 (1990). 


\begin{tabular}{|c|c|c|c|}
\hline $\begin{array}{l}\text { Document Control } \\
\text { Page }\end{array}$ & $\begin{array}{l}\text { 1. SERI Report No. } \\
\text { NREL/TP-214-4579 }\end{array}$ & $\begin{array}{l}\text { 2. NTIS Accession No. } \\
\text { DE92001199 }\end{array}$ & 3. Reciplent's Accession No. \\
\hline \multirow{2}{*}{\multicolumn{3}{|c|}{$\begin{array}{l}\text { 4. Title and Subtitle } \\
\text { Photovoltaic Manufacturing Technology, Phase } 1\end{array}$}} & $\begin{array}{l}\text { 5. Publication Date } \\
\text { March } 1992\end{array}$ \\
\hline & & & 6. \\
\hline \multicolumn{3}{|l|}{$\begin{array}{l}\text { 7. Author(s) } \\
\text { M. Izu }\end{array}$} & 8. Purforming Organization Rept. No. \\
\hline \multirow{2}{*}{\multicolumn{3}{|c|}{$\begin{array}{l}\text { 9. Pertorming Organization Name and Address } \\
\text { Energy Conversion Devices, Inc. } \\
\text { 1675 W. Maple Rd. } \\
\text { Troy, MI } 48084\end{array}$}} & $\begin{array}{l}\text { 10. Project/TaskWWork Unit No. } \\
\text { PV250101 }\end{array}$ \\
\hline & & & $\begin{array}{l}\text { 11. Contract (C) or Grant (G) No. } \\
\text { (C) XC-1-10057-11 } \\
\text { (G) }\end{array}$ \\
\hline \multirow{2}{*}{\multicolumn{3}{|c|}{$\begin{array}{l}\text { 12. Sponsoring Organization Name and Address } \\
\text { National Renewable Energy Laboratory } \\
1617 \text { Cole Blvd. } \\
\text { Golden, CO } 80401-3393\end{array}$}} & $\begin{array}{l}\text { 13. Type of Report \& Period Covered } \\
\text { Technical Report } \\
9 \text { January 1991 - } 14 \text { April } 1991\end{array}$ \\
\hline & & & 14. \\
\hline \multicolumn{4}{|c|}{$\begin{array}{l}\text { 15. Supplementary Notes } \\
\text { NREL technical monitor: R. Mitchell }\end{array}$} \\
\hline \multicolumn{4}{|c|}{$\begin{array}{l}\text { This report examines manufacturing multiple-band-gap, multiple-junction solar cells and photovoltaic modules. Amorphous } \\
\text { silicon alloy material is deposited (using microwave plasma-assisted chemical vapor deposition) on a stainless-steel substrate } \\
\text { using a roll-to-roll process that is continuous and automated. Rapid thermal equilibration of the metal substrate allows rapid } \\
\text { throughput of large-area devices in smaller production machines. Potential improvements in the design, deposition, and } \\
\text { module fabrication process are described. Problems are also discussed that could impede using these potential improvements. } \\
\text { Energy Conversion Devices, Inc. (ECD) proposes cost and time estimates for investigating and solving these problems. } \\
\text { Manufacturing modules for less than } \$ 1.00 \text { per peak watt and stable module efficiencies of greater than } 10 \% \text { are near-term } \\
\text { goals proposed by ECD. }\end{array}$} \\
\hline \multicolumn{4}{|c|}{$\begin{array}{l}\text { 17. Document Analysis } \\
\text { a. Descriptors } \\
\text { photovoltaic manufacturing ; amorpl } \\
\text { cells ; multijunction cells } \\
\text { b. Identiflers/Open-Ended Terms }\end{array}$} \\
\hline \multirow{2}{*}{\multicolumn{2}{|c|}{$\begin{array}{l}\text { 18. Availability Statement } \\
\text { National Technical Information Service } \\
\text { U.S. Department of Commerce } \\
\text { 5285 Port Royal Road } \\
\text { Springfield, VA } 22161\end{array}$}} & & $\begin{array}{l}\text { 19. No. of Pages } \\
92\end{array}$ \\
\hline & & & $\begin{array}{l}\text { 20. Price } \\
\text { A05 }\end{array}$ \\
\hline
\end{tabular}

Form No. 0069E (6-30-87) 

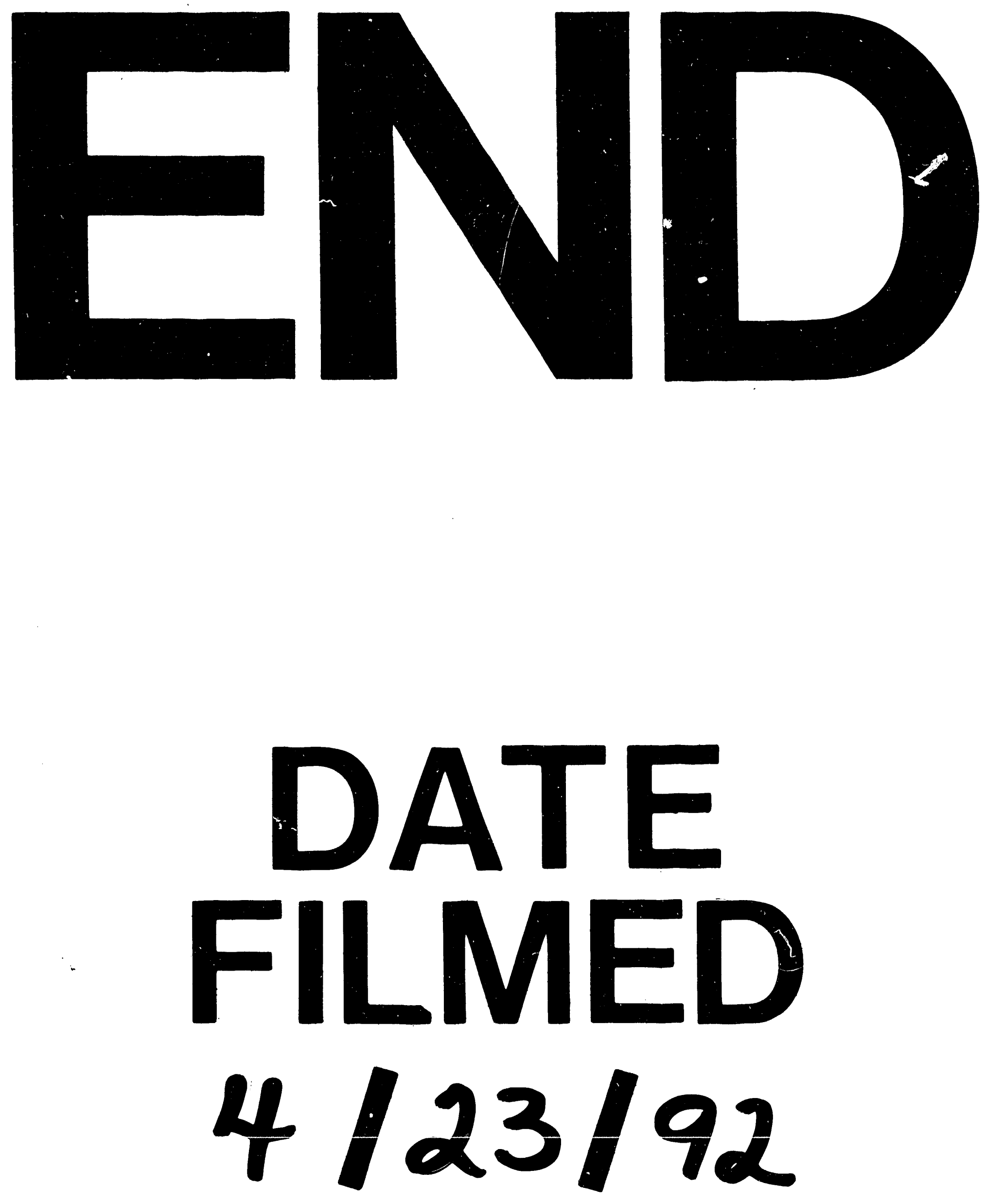


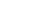

